Universidade de São Paulo

Faculdade de Medicina de Ribeirão Preto

Departamento de Genética

UM MODELO PARA ESTUDOS DE MODULAÇÃO DA PLURIPOTÊNCIA E DIFERENCIAÇÃO CELULAR EM CÉLULAS-TRONCO PLURIPOTENTES

Ildercílio Mota de Souza Lima

Ribeirão Preto - SP

2013 


\author{
Universidade de São Paulo \\ Faculdade de Medicina de Ribeirão Preto \\ Departamento de Genética
}

Ildercílio Mota de Souza Lima

\title{
UM MODELO PARA ESTUdOS DE MODULAÇÃO DA PLURIPOTÊNCIA E DA DIFERENCIAÇÃO CELULAR EM CÉLULAS-TRONCO PLURIPOTENTES
}

Dissertação apresentada ao Programa de PósGraduação em Genética da Faculdade de Medicina de Ribeirão Preto da Universidade de São Paulo, como parte dos pré-requisitos para obtenção do título de Mestre em Genética.

Área de concentração: Genética

Orientador: Dr. Rodrigo Alexandre Panepucci

Ribeirão Preto

2013 


\section{FICHA CATALOGRÁFICA}

Preparada pela Biblioteca Central do Campus Administrativo de Ribeirão Preto/USP.

Lima, Ildercílio Mota de Souza.

Um modelo para estudos de modulação da pluripotência e da diferenciação celular em células-tronco pluripotentes.

Ribeirão Preto, 2013.

Dissertação de Mestrado apresentada à Faculdade de Medicina de Ribeirão Preto/USP. Área de concentração: Genética.

Orientador: Panepucci, Rodrigo Alexandre.

1. Células-Tronco. 2. Pluripotência. 3. Diferenciação Celular. 4. NTera-2.

5. Ácido Trans-Retinóico. 


\section{FOLHA DE APROVAÇÃO}

Ildercílio Mota de Souza Lima

Um modelo para estudos de modulação da pluripotência e da diferenciação celular em células-tronco pluripotentes

Dissertação apresentada à Faculdade de Medicina de Ribeirão Preto da Universidade de São Paulo para obtenção do Título de Mestre em Ciências.

Área de Concentração: Genética

Aprovado em

\section{Banca examinadora}

Prof. Dr. Rodrigo Alexandre Panepucci

Instituição

Assinatura

Prof. Dr.

Instituição Assinatura

Prof. Dr.

Instituição Assinatura 
Dedico este trabalho aos que acreditam em mim, minha família de sangue e de coração. 


\section{AGRADECIMENTOS}

Em primeiro lugar, agradeço a Deus pelas oportunidades que me foram dadas por Ele. Agradeço-o pela vida, pelas dificuldades que surgiram durante esta fase, pois com elas eu cresci e amadureci, e também o agradeço pelas coisas boas e bons momentos que passei com pessoas mais que especiais que ele me possibilitou conhecer nestes últimos dois anos.

Ao meu orientador, Rodrigo Alexandre Panepucci, pela oportunidade e confiança que me foram dadas para que eu pudesse desenvolver o presente trabalho em seu laboratório, bem como por seus conselhos e dicas para a conclusão dos experimentos e desta dissertação.

Às três mulheres mais importantes da minha vida, minha mãe (Liduina), minha mãe dois (Maria de Fátima) e minha tia Nena (Ivanilce), por me apoiarem em momentos difíceis, por terem me ensinado lições e valores, os quais aplico em minha vida até hoje. Enfim, por terem sido meus espelhos, meus exemplos e fortaleza. Amo vocês!

Ao meu pai (Ildenildo), que sempre foi um grande encorajador para mim, me apoiando em minhas idéias e decisões, acreditando em mim quando dizia querer ser cientista, mesmo que eu não soubesse direito o que isso significava na época. Acredito que ele ficaria muito orgulhoso ao ver que meus sonhos estão sendo realizados.

Ao meu tio Vanilson (Francisco Osvanilson), por todo o carinho e apoio. Por ter servido como um exemplo para minha carreira acadêmica e, mesmo muitas vezes não estando presente devido à distância, sempre me apoiou quanto aos meus estudos e sempre me incentivou a crescer. 
Agradeço também aos meus demais familiares, que são muitos. Alguns participaram mais ativamente em minha vida, outros não tão diretamente, mas acredito que todos sempre me desejaram o bem e de alguma forma fazem parte de mim.

Às técnicas do Laboratório de Biologia Molecular I e Hematologia, Amélia Goes de Araújo (Meli), Marli Hayde e Tavella (Marli), Cláudia Helena Magnani Avelar (Craudinha e mãe de laboratório), Elizabete Tavares Figueiredo Auddino (Bete) e Júlia Mieko Yoshida Komoto (Julinha),pela imensa cooperação, a qual permitiu que o presente trabalho fosse desenvolvido com êxito. Agradeço também às técnicas do Laboratório de Imunofluorescência do Hemocentro de Ribeirão Preto, Danielle Aparecida Rosa de Magalhães (Dani) e Josiane Serrano Borges (Josi), por todo o apoio com relação aos experimentos de imunofluorescência.

À Josiane Lílian dos Santos Schiavinato (Josi Lílian), aluna de doutorado e também técnica do Laboratório de Biologia Molecular I e Hematologia, bem como uma amiga de valor inestimável, que me ajudou desde o início do meu mestrado, pois foi a primeira pessoa do laboratório com quem entrei em contato, foi quem me apresentou ao prof. Panepucci, quem teve a caixa de entrada lotada de meus e-mails desesperados e me recebeu em meu primeiro estágio no laboratório como candidato ao mestrado. Também me apoiou durante todo o período do curso e me deu dicas e conselhos que me serviram de suporte e me ajudaram a passar por este período.

Às pós-graduandas Mariane Serra Fráguas (Mari), Danuta Sastre (Dan ou Carolina Pacheco) e Lara Martinelli Zapatta (Larinha), que cooperaram diretamente em todo o desenvolvimento do meu trabalho, além de terem se tornado pessoas importantíssimas em minha vida, me ajudando não somente em questões relacionadas ao trabalho, mas também em questões pessoais, em momentos complicados e difíceis. Obrigado pela amizade, pelos risos e alegrias. Foi e continuará sendo ótchymon! 
Aos pós-graduandos Vitor Leão e Bruno Braga Sangiorge, pela amizade e apoio. Por terem sido responsáveis por momentos ímpares, divertidos, como também por me darem suporte em questões técnicas e científicas, por sempre estarem abertos a discussões importantes. Os amigos são a família que escolhemos.

Ao Dr. Rodrigo Haddad (Turquinho) e à Lucila Habib Bourguignon Oliveira (Luluzinha), pelo suporte e incentivo que me deram durante o desenvolvimento deste trabalho de mestrado. Mesmo que não continuemos hoje em dia no mesmo laboratório, vocês foram e continuarão sendo grandes amigos.

Aos meus amigos que não fazem parte do meu atual ambiente de laboratório. Amigos que sempre me incentivaram, que estiveram presentes em diferentes momentos da minha vida, amigos recentes ou de longas datas, amigos que se encontram próximos ou distantes, amigos que sempre terão um espaço reservado em minha vida.

Ao Departamento de Genética da FMRP/USP, pelo curso de excelência oferecido, e à Susie Adriana Penha Nalon, secretária do departamento, por sua prontidão e por sempre nos esclarecer sobre as dúvidas relacionadas à parte burocrática da pós-graduação.

Ao CNPq pela bolsa de mestrado, como também ao Hemocentro de Ribeirão Preto e à FAEPA pelo auxílio financeiro, o qual possibilitou a minha participação em eventos científicos. 
"Quão melhor é adquirir a sabedoria do que o ouro! e quão mais excelente é adquirir a prudência do que a prata!"

Provérbios 16:16 


\section{Resumo}

Lima, I.M.S . Um modelo para estudos de modulação da pluripotência e da diferenciação celular em células-tronco pluripotentes. Dissertação de Mestrado - Faculdade de Medicina de Ribeirão Preto, Universidade de São Paulo, Ribeirão Preto, 2013.

Células pluripotentes são aquelas que possuem a capacidade de dar origem às células dos três folhetos embrionários (ectoderma, mesoderma e endoderma), bem como também às células germinativas. As células-tronco embrionárias (CTE) são as células pluripotentes mais conhecidas, as quais apresentam uma elevada capacidade de diferenciação celular e autorenovação. Estas propriedades tornam as CTE potenciais ferramentas para a medicina regenerativa, porém seu uso na prática clínica enfrenta várias barreiras. Neste sentido, o acúmulo de conhecimento a respeito dos mecanismos envolvidos na manutenção da pluripotência, levou ao desenvolvimento de técnicas capazes de induzir a pluripotência em células somáticas adultas. Na maioria das abordagens, isto se dá pela expressão ectópica de fatores de transcrição envolvidos na pluripotência (como Oct4 e Nanog). Com isto em vista, torna-se evidente que estudos que levem a um melhor entendimento destas propriedades biológicas, podem levar ao desenvolvimento desta importante área. Apesar destas inovações, os mecanismos responsáveis pela manutenção ou indução da pluripotência e da autorenovação, continuam largamente inexplorados. Neste sentido, o conjunto de técnicas referidas como High Content Screening (HCS) apresenta características fundamentais que permitiriam a interrogação sistemática e em larga-escala de fatores que possam estar influenciando nestes processos. A técnica de HCS se baseia no uso de microscopia de fluorescência em placas de 96 ou mais poços, permitindo a aquisição e a análise automatizada das imagens, de forma a quantificar alterações fenotípicas nas células. O presente trabalho teve como objetivo estabelecer um modelo experimental para a avaliação funcional e em larga escala de fatores que possam influenciar a diferenciação celular. Tendo em vista a facilidade de cultivo e manuseio, a linhagem humana de células pluripotentes de carcinoma embrionário (CCE) NTera-2, foi utilizada. Para a padronização do modelo, o processo de diferenciação foi avaliado ao longo do tempo (em 2, 4 e 8 dias) na presença ou ausência de ácido transretinóico (atRA), utilizado como indutor de diferenciação celular. Para isso, os níveis transcricionais de Oct4, Nanog (marcadores da pluripotência) e de N-Caderina foram avaliados por PCR em tempo real. Finalmente, a expressão e a distribuição celular de Oct4, Nanog e da alfa-actina foi avaliada por meio de microscopia de fluorescência automatizada, com o uso de anticorpos ou faloidina marcada, utilizando um sistema de HCS (Operetta, Perkin Elmer) para a análise dos resultados. A proliferação celular das células submetidas à diferenciação foi avaliada pelo ensaio do XTT. O atRA inibiu a proliferação e induziu a diferenciação; como demonstrado, respectivamente, pelos resultados do ensaio do XTT, decaimento dos níveis de Oct4 e Nanog e, concomitante aumento de N-Caderina, ao longo do tempo. Também foi observada a diferenciação espontânea da linhagem, na ausência de atRA, porém, de forma reduzida. Finalmente, as avaliações de HCS evidenciaram que, durante o processo de diferenciação, a perda da expressão nuclear de Oct4 e Nanog está associada à alteração do fenótipo celular, com a redistribuição da actina cortical e a formação das stress fibers, caracterizando o processo de transição epitélio-mesenquima (EMT), um importante mecanismo envolvido na diferenciação celular. Os resultados obtidos neste trabalho demonstram a viabilidade do uso da linhagem NTera-2 como modelo para estudos futuros de HCS visando a identificação de moléculas que atuem na modulação de propriedades fundamentais das células tronco pluripotentes.

Palavras-chaves: Células-Tronco, Pluripotência, Diferenciação Celular, NTera-2, Ácido Trans-retinóico. 


\begin{abstract}
Lima, I.M.S . A model for studying the modulation of pluripotency and cell differentiation in pluripotent stem cells. Faculdade de Medicina de Ribeirão Preto, Universidade de São Paulo, Ribeirão Preto, 2013.
\end{abstract}

Pluripotent stem cells are those that possess the ability to generate cells from the three germ layers (ectoderm, mesoderm and endoderm), as well as the germ cells. The embryonic stem cells (ESC) are the best known pluripotent cells that present a high capacity of cell differentiation and self renewal. These properties of the ESC make them potential tools for the regenerative medicine, but their use in clinical practice faces several barriers. In this sense, the accumulation of knowledge about the mechanisms involved in the maintenance of pluripotency led to the development of techniques capable of inducing pluripotency in adult somatic cells. In most approaches, this is achieved by the ectopic expression of transcription factors involved in pluripotency (such as Oct4 and Nanog). With this in mind, it becomes clear that studies that provide a better understanding of these biological properties can lead to the development of this important area. Despite these innovations, the mechanisms responsible for the maintenance or induction of pluripotency and self-renewal remain largely unexplored. In this sense, the set of techniques such as High Content Screening (HCS) has fundamental characteristics that allow systematic and large-scale interrogation of factors that may be influencing these processes. The HCS technique is based on the use of fluorescence microscopy in 96-well or larger plates, allowing the automated acquisition and analysis of images, so as to measure phenotypic changes in the cells. This study aimed to establish an experimental model for functional and large-scale assessment of factors that may influence cellular differentiation. Due its simple cultivation and handling characteristics, a human lineage of pluripotent embryonal carcinoma cell (ECC) NTERA-2 was used. To standardize the model, the process of differentiation was evaluated over time (at 2, 4 and 8 days) in the presence or absence of all-trans retinoic acid (atRA), used as an inducer of cellular differentiation. The transcriptional levels of Oct4, Nanog (pluripotency markers) and $\mathrm{N}$ cadherin were assessed by real time PCR. Finally, the expression and cellular distribution of Oct4, Nanog and alpha-actin was assessed by fluorescence microscopy, using antibodies or labelled phalloidin, using a HCS platform (Operetta, Perkin Elmer) for the analysis of the results. The proliferation of cells undergoing differentiation was assessed by XTT assay. atRA inhibited proliferation and induced differentiation, as shown by the XTT assay results, and the decay of Oct4 and Nanog, and concomitant increase of N-cadherin levels over time, respectively. It was also observed spontaneous differentiation in the absence of atRA although in less extent. Finally, the HCS results showed that during the differentiation process, the loss of nuclear expression of Oct4 and Nanog is associated with alteration of cell phenotype, with redistribution of cortical actin and formation of stress fibers, characterizing the epithelialmesenchymal transition (EMT), an important mechanism involved in cell differentiation. The results of this study therefore demonstrate the feasibility of using the NTERA-2 cell line as a model for future HCS studies aiming identification of molecules that act in the modulation of fundamental properties of pluripotent stem cells.

Key-words: Stem Cells, Pluripotency, Cell differentiation, NTera-2, All-trans-retinoic Acid. 


\section{SUMÁRIO}

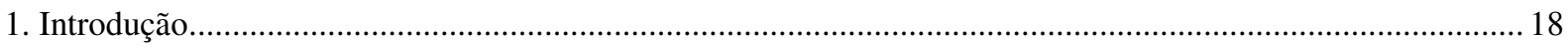

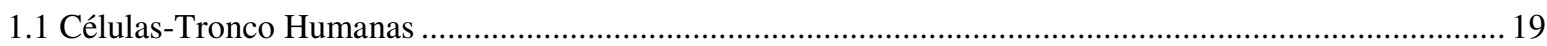

1.2 Reprogramação Nuclear e as Bases Moleculares da Pluripotência ........................................................23

1.3 Células de Carcinoma Embrionário como Modelo para o Estudo das CTE ........................................28

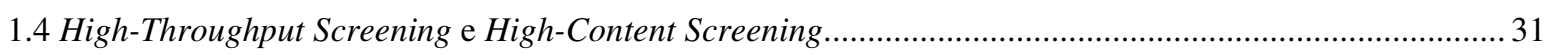

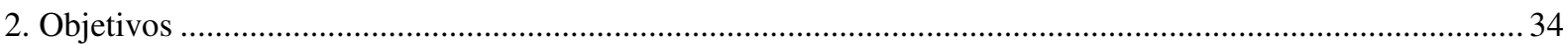

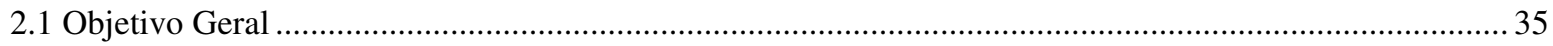

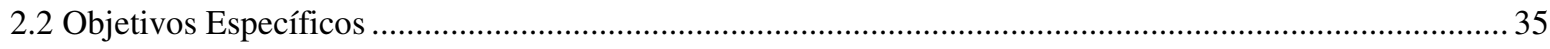

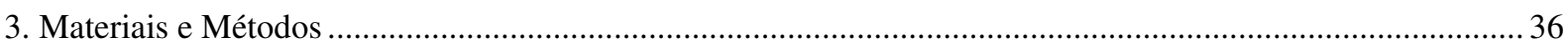

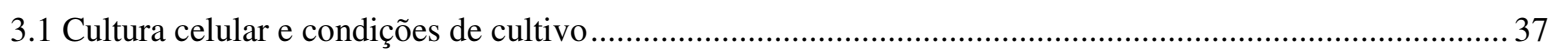

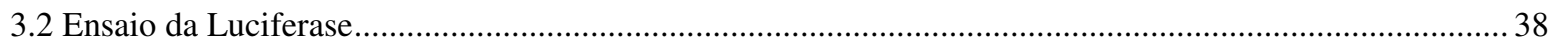

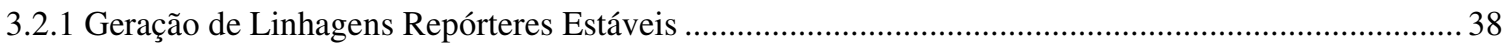

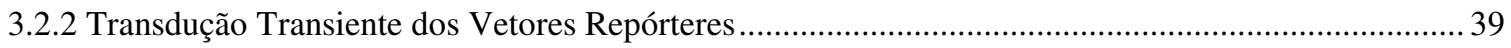

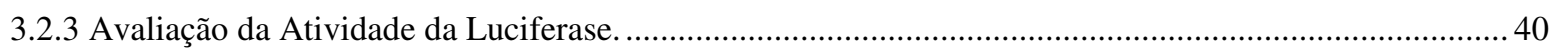

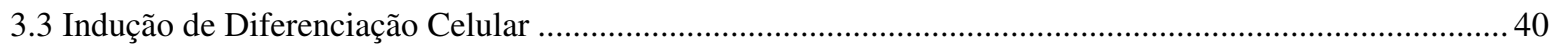

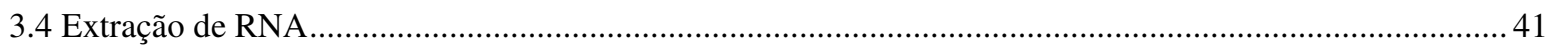

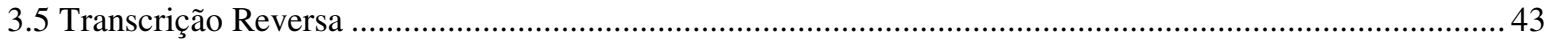

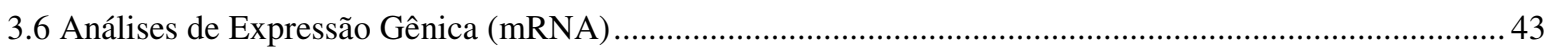

3.7 Análises de imunofluorescência - High Content Screening (HCS) .......................................................45

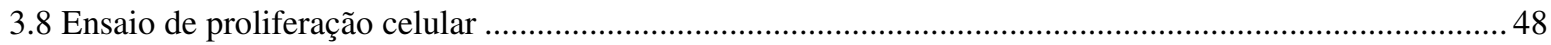

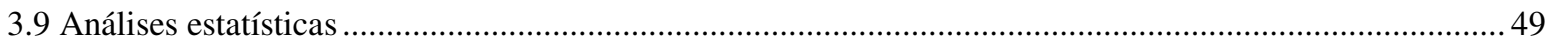

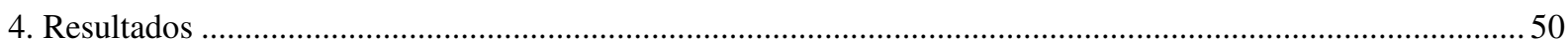

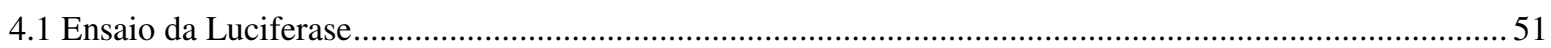

4.1.1 Geração de Linhagens Repórteres Estáveis ........................................................................... 51

4.1.2 Ensaios com as Linhagens Repórteres Transientes................................................................ 52

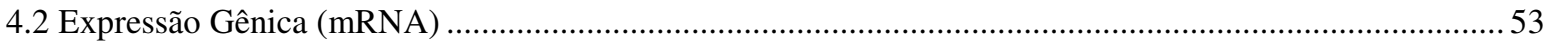

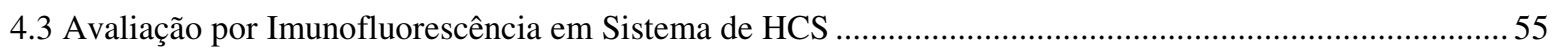

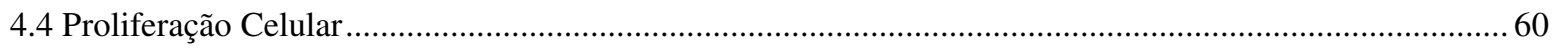

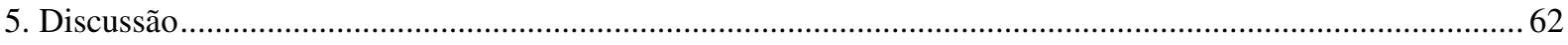

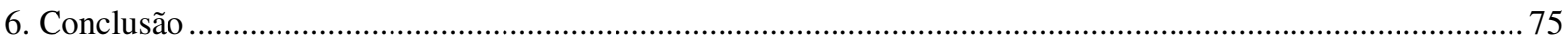

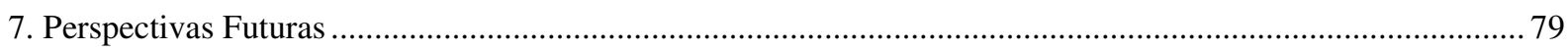

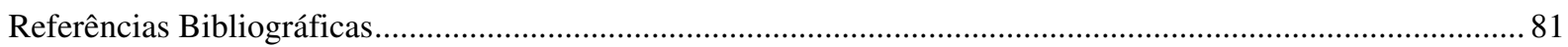




\section{Lista de Ilustrações}

Figura 1 Representação dos diferentes tipos de células-tronco encontradas durante o desenvolvimento, classificadas de acordo com sua capacidade de diferenciação e local de origem. Fonte: Behr e colaboradores (2010).

Pág. 20

Figura 2 Desenho representativo de um embrião de mamífero, no estágio de blastocisto, apontando a massa celular interna (que dará origem ao embrião), o trofectoderma ou trofoblasto (que dará origem à placenta) e a blastocele (cavidade interna da blástula). Fonte: Miguel e colaboradores (2010)... Pág. 22

Figura 3 Esquema representando a geração de uma iPSC (induced pluripotent stem cell) por meio do uso de vetores retrovirais para a expressão ectópica de fatores de pluripotência. Esta figura representa o trabalho realizado por Takahashi e Yamanaka (2006). Fonte: Yamanaka e Blau (2010).

Pág. 23

Figura 4 a) Representação da técnica de Transferência Nuclear; b) Representação da técnica de Fusão Celular. Fonte: Yamanaka e Blau (2010).

Pág. 25

Figura 5 microRNAs expressos diferencialmente de acordo com o grau de diferenciação celular. Enquanto miRNAs como miR-290 e miR-302 encontram-se elevados em células pluripotentes, outros miRNAs como Let-7, miR-145 e miR-124 só começam a ser expressos quando as células se encontram mais diferenciadas. Fonte: Tollervey e Lunyak (2012).

Pág. 28

Figura 6 Representação histórica dos experimentos realizados para entendimento das características e biologia de células de carcinoma embrionário (CCE). Iniciando-se da parte superior esquerda, foi gerado um teratoma a partir de um embrião ("F1") cromossomicamente macho (XY) da linhagem 129 de pais agouti pretos. Esse embrião foi implantado em outro animal e gerou um tumor metastático no nódulo renal. O tumor primário foi transplantado intraperitonialmente, gerando um tumor ascítico de corpos embrióides. Após alguns anos, as CCE obtidas dos corpos embrióides foram implantadas em blastocistos gerados de pais não-agouti e transferidos para uma "barriga de aluguel". Como resultado, foram obtidos camundongos normais com mosaicismo na pelagem (listrados) e/ou contribuições teciduais internas das células de CCE. Um macho mosaico adulto foi cruzado com fêmeas marrons e gerou prole semelhantes à "F1", provando a presença de espermas normais de células de teratocarcinoma. Fonte da imagem: Mintz and Illmensee (1975).

Pág. 30

Figura 7 Esquema representativo do vetor lentiviral utilizado para a geração do vírus Cignal Lenti Reporters, os quais transmitem à célula a característica de produzir um determinado gene repórter (no presenta caso a luciferase) em resposta à presença de um fator de transcrição (ex.: Oct4, Nanog e RAR). Fonte: Cignal $^{\mathrm{TM}}$ Lenti Reporters User Manual .....

Pág. 38

Figura 8 Esquematização da realização do Ensaio da Luciferase, de maneira transiente, em células NTera-2 e BJ.

Pág. 40

Figura 9 Esquema representativo do protocolo de indução de diferenciação celular, utilizado para os diferentes estudos do presente trabalho. Nele encontram-se descritos os tempos de tratamentos, renovação do meio de cultura (com ou sem atRA) e os momentos em que foram realizadas as obtenções de amostras para a realização dos experimentos independentes, os quais encontram-se descritos posteriormente.

Figura 10 Representação do procedimento passo-a-passo utilizado para a realização das análises de imagens, feitas por meio do uso do software Harmony 3.0 
Figura 11 Nesta imagem encontram-se representadas três fotomicrografias (a, b e c) de culturas de células submetidas à transdução com partículas lentivirais e posteriormente selecionadas com antibiótico específico. Essas células apresentam uma morfologia diferente das células saudáveis (d) e perdem seu potencial de proliferação. Pág. 51

Figura 12 Gráfico apresentado os valores de intensidade de luminescência média e desvio padrão, obtidos das células BJ e NTera2 transduzidas com repórteres para atividade transcricional de Oct4 e Nanog. *diferente do grupo BJ $(p<0,0001)$

Figura 13 Variação das médias dos níveis de expressão dos transcritos Oct4 (a), Nanog (b) e N-Caderina (c) nos grupos tratado e no controle não tratado com atRA após 2 dias de cultura celular, representada em gráficos. *diferente do grupo controle $(p<0,0001)$; Ctrl D2: Controle do dia 2; atRA D2: Tratamento com ácido trans-retinóico do dia 2

Pág. 54

Figura 14 Gráficos representando a variação das médias dos níveis de expressão dos transcritos Oct4 (a), Nanog (b) e N-Caderina (c) nos grupos tratado com atRA e controle após 4 dias de cultura celular. *diferente do grupo controle $(p<0,0001)$; Ctrl D4: Controle do dia 4; atRA D4: Tratamento com ácido transretinóico do dia 4

Figura 15 Representação em gráficos das médias dos níveis de expressão dos transcritos Oct4 (a), Nanog (b) e N-Caderina (c) nos grupos tratado e não tratado com atRA após 8 dias de cultura celular. *diferente do grupo controle $(p<0,0001)$; Ctrl D8: Controle do dia 8; atRA D8: Tratamento com ácido transretinóico do dia 8 .

Pág. 55

Figura 16 Representação da variação dos níveis de expressão dos transcritos Oct4, Nanog e N-Caderina nos grupos tratado e não tratado com atRA, nos tempos de 2, 4 e 8 dias de cultura celular em comparação às células do grupo controle do dia 2 .

Pág. 55

Figura 17 Fotomicrografias obtidas de culturas de células tratadas ou não com ácido trans-retinóico (atRA), marcadas com anticorpos anti-Oct4 ou anti-Nanog (Alexa488, verde), faloidina (Texas Red, vermelho) e DAPI (azul). Nesta figura é possível observar a presença ou ausência da expressão destes fatores de transcrição, observando-se a marcação de Alexa488, que se co-localiza com a marcação nuclear. Também é possível observar a variação da estrutura de actina pela marcação com faloidina. (Aumento: 200X) Pág. 58

Figura 18 Representação em gráficos dos valores médios de intensidade de fluorescência de Alexa488 na região nuclear das células marcadas com anti-Oct4 (a) ou anti-Nanog (b), tratadas com ácido trans-retinóico (atRA) ou não (Ctrl), mantidas em cultura celular por 2, 4 e 8 dias consecutivos. ${ }^{\text {a-c }}$ Letras diferentes representam diferenças estatisticamente significativas $(p<0,01)$.

Pág. 59

Figura 19 Gráficos apresentando os valores médios da porcentagem de núcleos Alexa488+ de células marcadas com anti-Oct4 (a) ou anti-Nanog (b), tratadas com ácido trans-retinóico (atRA) ou não (Ctrl), mantidas em cultura celular por 2, 4 e 8 dias consecutivos. ${ }^{\text {a-e }}$ Letras diferentes representam diferenças estatisticamente significativas $(p<0,01)$. Pág. 59

Figura 20 Imagem gerada a partir da fotomicrografia de quatro campos obtidas de culturas de células não submetidas ao tratamento com ácido trans-retinóico após 8 dias em cultura celular. Em azul encontrase marcada a estrutura do citoesqueleto de actina, em vermelho os núcleos marcados somente com DAPI e em amarelo/alaranjado (variando de acordo com a intensidade de marcação com anti-Oct4) os 
núcleos com dupla marcação de DAPI e Alexa488. Nesta figura é possível observar células diferenciadas (núcleo vermelho) e células indiferenciadas (núcleo amarelo/alaranjado), como também a estrutura do citoesqueleto de actina, o que nos possibilita a visualização das stress fibers e também de citoplasmas maiores nas células diferenciadas (Aumento: 200X) 60

Figura 21 Representação em gráfico dos resultados da análise de proliferação celular obtidos por meio do ensaio do XTT em culturas de NTera-2 tratadas com ácido trans-retinóico (atRA) por diferentes períodos de tempo, sendo estes 2,4 e 8 dias. *diferente do grupo controle $(p<0,001)$ Pág. 61

Figura 22 Representação em dos valores médios de absorbância obtidos por meio do ensaio do XTT em culturas de NTera-2 tratadas ou não com ácido trans-retinóico (atRA) pelo período de 2, 4 e 8 dias. ...... Pág. 61 


\section{LISTA DE ABREVIATURAS E SIGLAS}

- $\quad$ atRA = do inglês "all-trans Retinoic Acid"

- $\mathrm{BMP}=$ do inglês "Bone Morphogenic Proteins"

- $\mathrm{CCE}=$ Células de Carcinoma Embrionário

- $\mathrm{CD}=$ do inglês "Cluster of Differentiation"

- $\mathrm{CMV}=$ Citomegalovírus;

- $\mathrm{CT}=$ Células-Tronco

- $\mathrm{Ct}=$ do inglês "Cycle Threshold"

- $\quad$ CTE $=$ Células-Tronco Embrionárias

- $\mathrm{Ctrl}=$ Controle;

- DAPI = 4',6-diamidino-2-fenilindol

- DMEM = do inglês "Dulbecco's Modified Eagle's Medium"

- DMSO = Dimetilsulfóxido;

- $\mathrm{EMT}=$ do inglês "Epithelial-Mesenchymal Transition";

- $\quad$ FT = Fator(es) de Transcrição

- $\mathrm{HCS}=$ do inglês "High Content Screening"

- $\mathrm{HCT}=$ do inglês "Human Colorectal” (Cancer Cells);

- HLA = do inglês "Human Leucocyte Antigens"

- $\mathrm{HMBA}=$ do inglês "Hexamethylene Bisacetamide"

- $\operatorname{Hox}=$ Homeobox;

- HTS = do inglês "High-Throughput Screening"

- $\quad$ IL = Intensidade de Luminescência;

- $\quad \mathrm{iPSC}=$ do inglês "Induced Pluripotent Stem Cells" 
- $\quad$ MET = do inglês "Mesenchymal-Epithelial Transition";

- $\mathrm{MOI}=$ do inglês "Multiplicity of Infection";

- $\mathrm{PBS}=$ do inglês "Phosphate Buffered Saline";

- $\quad$ PCR = do inglês "Polimerase Chain Reaction";

- $\quad$ RAR = Receptor de Ácido Retinóico;

- $\mathrm{SBF}=$ Soro Bovino Fetal;

- SSEA = do inglês "Stage Specific Embryonic Antigen"

- TGF- $\beta=$ do inglês "Tumoral Growth Factor- $\beta$ ”;

- $\quad$ TRA = do inglês "Tumor Related Antigen";

- $\mathrm{XTT}=$ 3-[1-(fenil amino carbonil)-3,4-tetrazólio]-bis(4-metil-6-nitro) ácido benzeno sulfonato sódio hidratado. 


\subsection{Células-Tronco Humanas}

As células-tronco (CT) são células que possuem a capacidade de auto-renovação e de diferenciar-se em diferentes tipos celulares. Essas células podem ser obtidas durante vários estágios da vida (Fig. 01) (Behr et al., 2010). No geral, as CT se encontram em um microambiente específico, conhecido como nicho, o qual permite um diálogo espaço-temporal entre as CT e as células do nicho, o que leva a uma homeostase celular das CT. As células do nicho realizam a nutrição e participam da manutenção das CT, secretando fatores específicos ou regulando o microambiente, impedindo que assim as CT sofram estímulos de diferenciação, apoptose ou outros estímulos que venham a ameaçar o estoque de CT (Moore and Lemischka, 2006; Schofield, 1978).

De acordo com o seu potencial de diferenciação, as CT são classificadas em cinco grupos: totipotentes, pluripotentes, multipotentes, oligopotentes e unipotentes (Kolios e Moodley, 2013; Smith, 2006). As CT totipotentes são aquelas células que se encontram no seu estado mais indiferenciado e são encontradas na fase mais inicial do desenvolvimento, ou seja, no oócito recém-fecundado (zigoto) e nas células originadas até as duas primeiras divisões celulares sofridas por ele, sendo capazes de originar os tecidos dos anexos extraembrionários, como a placenta (Kolios e Moodley, 2013; Rossant, 2001); as CT pluripotentes são aquelas capazes de dar origem às células dos três folhetos embrionários (ectoderma, mesoderma e endoderma), bem como à linhagem germinativa (Gaspar-Maia et al., 2011; Miguel, De, Fuentes-Julián e Alcaina, 2010; Thomson, 1998); as CT multipotentes originam células de um único folheto germinativo e são encontradas em diversos tecidos adultos (Behr et al., 2010; Grigoriadis, Heersche e Aubin, 1988; Ratajczak et al., 2012); as CT oligopotentes são capazes de dar origem a duas ou mais linhagens de um tecido específico (Kim et al., 2005; Majo et al., 2008; Marone et al., 2002) enquanto as unipotentes são aquelas capazes de se diferenciar em somente um tipo celular específico e formar uma linhagem 
celular única (Beck e Blanpain, 2012; Bentzinger et al., 2013; Overturf et al., 1997; Rooij, de e Grootegoed, 1998).

Além da classificação por seu por seu potencial de diferenciação, as CT também podem ser caracterizadas pela sua origem. De acordo com isso, essas células podem ser classificadas em CT embrionárias, fetais, adultas e, mais recentemente, em iPSC (induced pluripotent stem cells) (Bongso e Richards, 2004; Ilic e Polak, 2011).

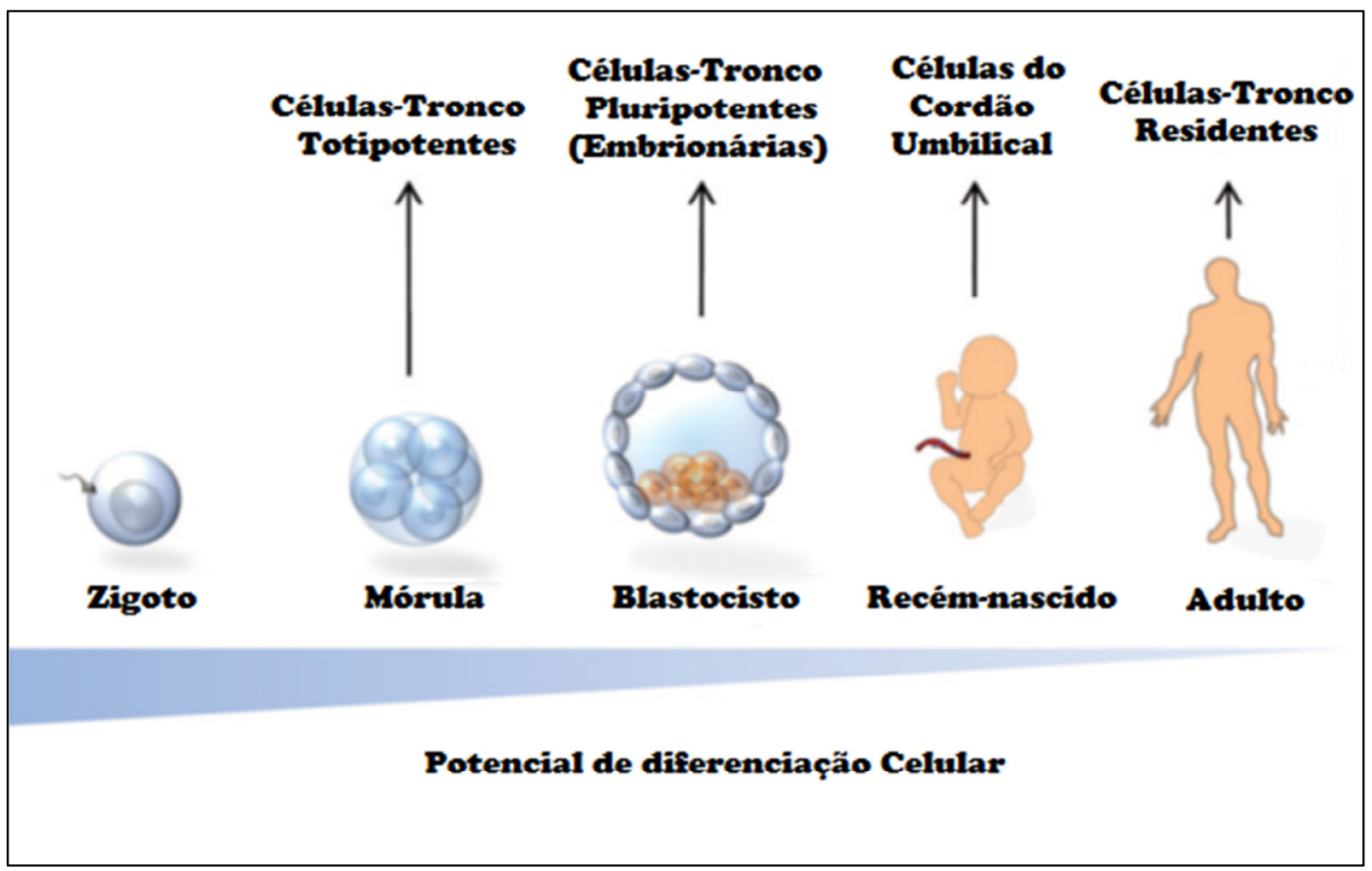

Figura 1 Representação dos diferentes tipos de células-tronco encontradas durante o desenvolvimento, classificadas de acordo com sua capacidade de diferenciação e local de origem. Fonte: Behr e colaboradores (2010).

As CT adultas são aquelas derivadas de tecidos adultos e como exemplos podem ser citadas as CT derivadas do tecido placentário e as CT mesenquimais, também conhecidas como células mesenquimais estromais. Esse grupo de células possui um menor potencial de diferenciação celular (Ilancheran, Moodley e Manuelpillai, 2009; Moodley et al., 2010).

Dentre as CT adultas, as CT mesenquimais são muito estudadas para propósitos de engenharia tecidual. Elas são caracterizadas por sua capacidade plástico-aderente quando mantidas em cultura celular padrão; expressam os marcadores de superfície CD73, CD90 e 
CD105 e não expressam CD14, CD34, CD45, CD11b, CD79, CD19 e HLA-DR; e são capazes de dar origem a osteoblastos, condrócitos e adipócitos quando submetidos a estímulos específicos in vitro (Behr et al., 2010; Dominici et al., 2006; Horwitz et al., 2005).

A obtenção de CT mesenquimais já foi realizada nos mais diferentes tecidos, como medula óssea (Grigoriadis, Heersche e Aubin, 1988; Gronthos, 2003; Sekiya et al., 2002), sangue de cordão umbilical (Lee et al., 2004), placenta (Tsagias et al., 2011) e tecido adiposo (Zuk et al., 2001, 2002). O tecido de origem da CT mesenquimal parece ser o principal fator determinante sobre suas características, tais como capacidade de diferenciação e proliferação (Kern et al., 2006).

Outro tipo de CT adultas são as tecido-específicas ou residentes-teciduais. Estas células já foram identificadas em praticamente todos os tecidos e órgãos pós-natais (Mimeault, Hauke e Batra, 2007) e são responsáveis pela renovação ou reparo de tecidos e órgãos, motivada por algum tipo de lesão, gerando células terminalmente diferenciadas que são tecido-específicas (Passier e Mummery, 2003).

As CT embrionárias (CTE) são células pluripotentes, derivadas da massa celular interna do blastocisto (Fig. 02), um estado do embrião pré-implantação, formado no período de 5-6 dias após a fertilização (Evans e Kaufman, 1981; Odorico, Kaufman e Thomson, 2001). Estas células podem dar origem a todos os tipos celulares derivados dos três folhetos germinativos, como também às células germinativas e podem ser mantidas em cultura celular, em seu estado indiferenciado, por um longo período de tempo se mantidas sob condições especiais de cultivo (Gaspar-Maia et al., 2011; Thomson, 1998; Yao et al., 2006).

Desde o isolamento bem sucedido de CTE de camundongos e humanos, o seu grande potencial terapêutico tem chamado a atenção da comunidade científica e vários estudos vêm sendo realizados para se descobrir formas de se aplicar as características especiais desta célula à terapêutica bem como compreender os mecanismos envolvidos na manutenção do estado 
pluripotente e na regência do comprometimento celular (Martin, 1981; Meissner, 2010; Niwa, 2011; Niwa et al., 1998; Thomson, 1998).

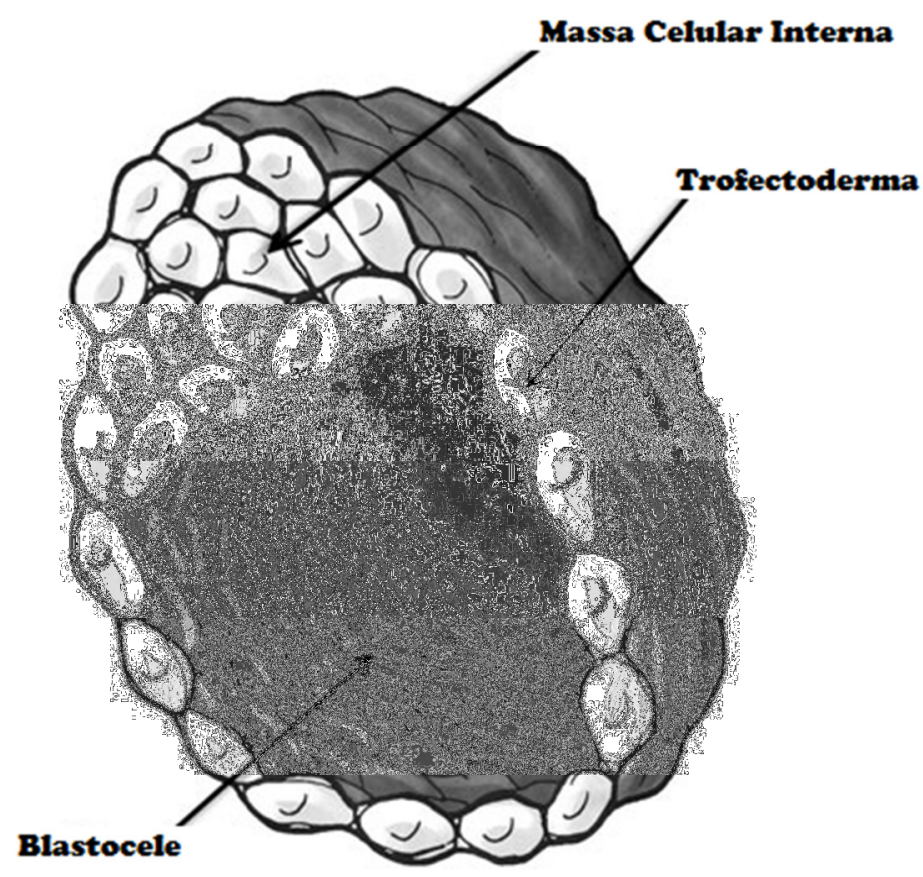

Figura 2 Desenho representativo de um embrião de mamífero, no estágio de blastocisto, apontando a massa celular interna (que dará origem ao embrião), o trofectoderma ou trofoblasto (que dará origem à placenta) e a blastocele (cavidade interna da blástula). Fonte: Miguel e colaboradores (2010).

Apesar de seu potencial uso para a medicina regenerativa, o uso das CTE na prática clínica é inviável por motivos tais quais a discussão ética em torno do uso de embriões humanos para a obtenção destas células e a necessidade de compatibilidade imunológica entre o paciente e a célula transplantada, para se evitar rejeição tecidual; ou ainda, devido ao seu alto potencial de malignização se implantada ainda indiferenciada (Gaspar-Maia et al., 2011; Suárez-Alvarez et al., 2010).

A geração de células totipotentes a partir de células diferenciadas surgiu como uma possível resolução para os problemas relacionados à questão ética e à compatibilidade imunológica, pois o uso de embriões humanos para a obtenção das CTE não seria mais necessário e as células adultas seriam obtidas de tecidos do próprio paciente, diminuindo as chances de incompatibilidade imunológica (Tada et al., 2001; Wilmut et al., 2007). 


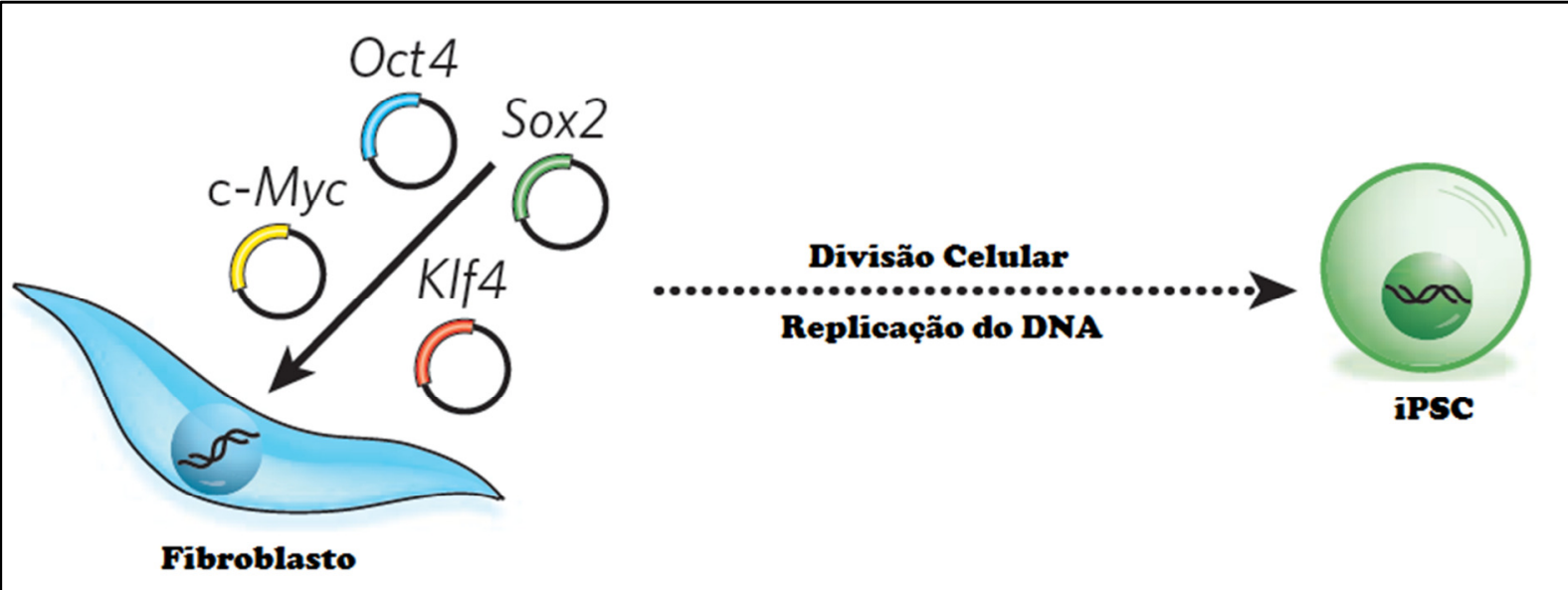

Figura 3 Esquema representando a geração de uma iPSC (induced pluripotent stem cell) por meio do uso de vetores retrovirais para a expressão ectópica de fatores de pluripotência. Esta figura representa o trabalho realizado por Takahashi e Yamanaka (2006). Fonte: Yamanaka e Blau (2010).

O processo utilizado para a produção de células iPSC é conhecido como reprogramação nuclear, o qual permite que células somáticas de adultos (já diferenciadas) retornem ao estado indiferenciado de células pluripotentes (Egli, Birkhoff e Eggan, 2008; Jaenisch e Young, 2008), por meio da expressão ectópica de fatores indutores de pluripotência (Fig. 03). A primeira geração de iPSC obtidas com sucesso ocorreu por uma super-expressão ectópica de fatores de transcrição relacionados à pluripotência, pelos pesquisadores Takahashi e Yamanaka (2006).

\subsection{Reprogramação Nuclear e as Bases Moleculares da Pluripotência}

Os primeiros estudos voltados à compreensão das bases moleculares da pluripotência datam das primeiras décadas de 1900. O trabalho de Briggs e King (1952) foi pioneiro em demonstrar a possibilidade de se transplantar o núcleo de uma célula em um estado pouco diferenciado (blástula avançada de Rana pipiens) para um oócito enucleado (Fig. 04a) e conseguir obter um embrião normal, que poderia evoluir até o seu estágio adulto. Dez anos após a realização deste experimento, Gurdon (1962) demonstrou, pela primeira vez, que era possível gerar um novo indivíduo a partir da reprogramação nuclear induzida pela transferência de um núcleo de célula somática, obtida de um tecido adulto, para um oócito 
enucleado. Em 1997, em experimento semelhante, Wilmut e seus colaboradores geraram uma ovelha a partir da clonagem de um núcleo somático de uma célula de epitélio mamário. Ambos os resultados corroboraram à hipótese de que o núcleo, mesmo que de uma célula já diferenciada, possui toda a informação necessária para a geração de um novo indivíduo e também que o(s) fatore(s) responsável(eis) pela reprogramação deste núcleo somático, e consequentemente responsável(eis) por conferir o fenótipo pluripotente ao zigoto, se encontrava(m) no citoplasma do oócito.

Em 2001, Tada e colaboradores comprovaram ser possível realizar a reprogramação nuclear de células somáticas por meio da fusão destas células com CTE (Fig. 04b). Este achado demonstrou que os mesmos fatores encontrados no citoplasma do oócito poderiam estar presentes no citoplasma das CTE, promovendo então a reprogramação do núcleo somático e a manutenção do estado pluripotente das CTE. Essas observações, juntamente às observações de Schneuwly e colaboradores (1987) e de Davis e colaboradores (1987), os quais descreveram fatores de transcrição que podiam determinar e induzir a mudança do fenótipo de certa linhagem celular para outro fenótipo, e também às informações relacionadas à manutenção e propagação de CTE in vitro, por meio do uso de alguns fatores específicos (Evans e Kaufman, 1981; Martin, 1981; Smith et al., 1988; Thomson, 1998), levaram à hipótese de que a combinação de múltiplos fatores era responsável pela reprogramação nuclear ao estado embrionário e pela manutenção do estado pluripotente das CTE. 


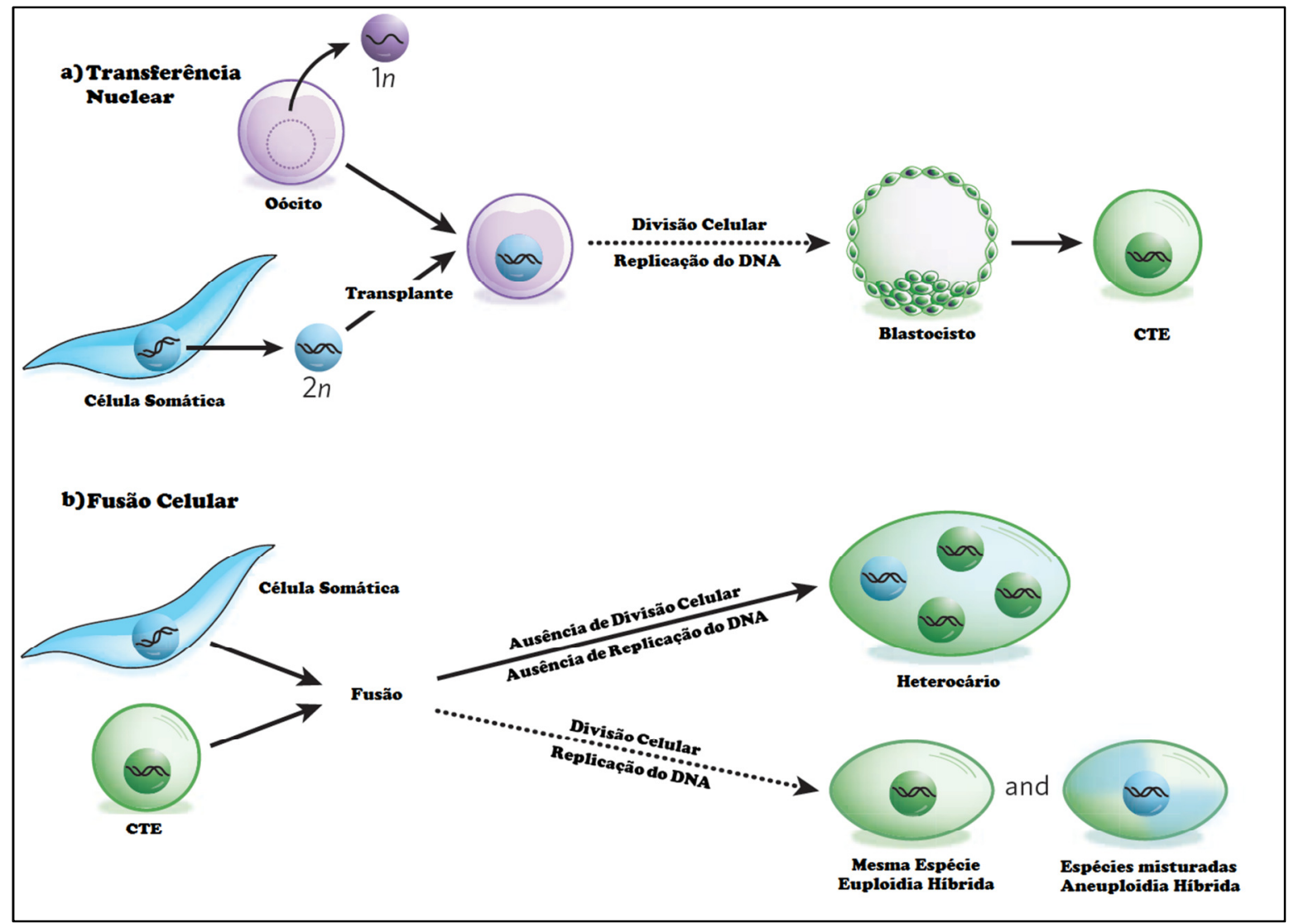

Figura 4 a) Representação da técnica de Transferência Nuclear; b) Representação da técnica de Fusão Celular. Fonte: Yamanaka e Blau (2010).

Análises comparativas entre os transcriptomas de CTE e células diferenciadas revelaram um grande número de genes diferencialmente expressos, candidatos a serem possíveis determinantes do fenótipo pluripotente destas células. No trabalho realizado por Sato e colaboradores (2003) foram observados 918 transcritos enriquecidos em uma linhagem celular de CTE, quando comparadas aos seus pares diferenciados.

Estudos funcionais revelaram que diferentes fatores de transcrição (FT) são de grande importância para o controle do estado pluripotente das CTE (Chambers et al., 2003, 2007; Ema et al., 2008; Fujikura et al., 2002; Masui et al., 2007; Niwa, Miyazaki e Smith, 2000; Niwa et al., 2005), e fatores como Oct4, Sox2 e Nanog têm função central neste processo, por meio de uma rede transcricional (Boyer et al., 2005; Loh et al., 2006).

Em 2006, Takahashi e Yamanaka foram capazes de induzir um fenótipo de pluripotência em células somáticas utilizando partículas retrovirais que codificavam FT 
altamente expressos em CTE, como representado anteriormente na Figura 03. Essas células foram então chamadas de células-tronco de pluripotência induzida ou iPSC.

Embora a grande maioria dos estudos sobre a regulação do estado de pluripotência das CTE esteja voltada para a avaliação do transcriptoma destas células, pesquisas recentes têm demonstrado que o genoma destas, sofre grandes alterações epigenéticas durante a diferenciação celular (Reik, 2007). A regulação da auto-renovação e do status de diferenciação das CT não está somente ligada à rede de fatores de transcrição, mas também às propriedade da cromatina dessas células (Tollervey e Lunyak, 2012).

Durante o desenvolvimento embrionário, as CT passam pelos vários estados de potencial de diferenciação (de totipotentes para pluripotentes, então para multipotentes e assim por diante) e essas modificações de fenótipo são reguladas pelo silenciamento de genes relacionados ao estado mais indiferenciado e expressão de um novo conjunto de genes célulaespecíficos. Esse processo é resultante da expressão seletiva de FT que é regida por fatores epigenéticos: remodelamento da cromatina ou modificações de cromatina, metilação do DNA e atividade dos RNAs não codificadores (Lessard e Crabtree, 2010; Li, 2002; Williams et al., 2006).

É sabido que a cromatina das CTE é constituída prevalentemente por eucromatina, ou seja, cromatina menos condensada e mais transcricionalmente ativa, enquanto a heterocromatina é mais observadas em células diferenciadas. Essas diferenças são regidas por modificações de histonas (Meshorer et al., 2006; Rasmussen, 2003).

A metilação do DNA é um exemplo clássico de modificações epigenéticas de grande importância para o controle de expressão gênica durante o desenvolvimento e também um dos mecanismos de controle das características fenotípicas das CT (Tollervey e Lunyak, 2012). Nas linhagens germinativas, os genes envolvidos com o controle da diferenciação célular encontram-se transcricionalmente inativos devido à metilação de seus promotores, porém, nos 
estágios iniciais da embriogênese, nas células germinativas e no embrião pré-implantação, o genoma sofre uma reprogramação dos padrões de metilação e após a fertilização o genoma parental sofre uma demetilação acentuada durantes as primeiras divisões celulares (Popp et al., 2010; Rai et al., 2008; Reik, 2012).

Essa demetilação global do genoma no início da embriogênese libera o acesso a regiões promotoras de genes que, anteriormente se encontravam inacessíveis e silenciados. Dentre estes genes estão aqueles necessários para a manutenção do estado pluripotente das CT, tais como Nanog e Oct4 (Yamanaka, 2009).

Mais recentemente, junto aos mecanismos epigenéticos já conhecidos para o controle da dinâmica celular, foram descritos RNAs não-codificantes que atuam regulando a expressão gênica (Mattick et al., 2009). Dentre estes RNAs não-codificantes encontram-se os microRNAs (miRNA), que são pequenos RNAs que regulam a expressão gênica de maneira póstranscricional por meio da degradação ou inibição da tradução de RNAs mensageiros (mRNA) alvos (Bartel, Lee e Feinbaum, 2004). Em mamíferos, esses miRNAs parecem agir predominantemente reduzindo os níveis de mRNAs alvo (Bartel, 2009; Grimson et al., 2007; Guo et al., 2010; Mourelatos, 2008).

Recentemente foram identificados grupos de miRNAs que são expressos em altos níveis nas CTE e cujos níveis reduziam durante a diferenciação e, alternativamente, grupos de miRNAs cujos níveis de expressão (ausentes ou baixos nas células pluripotentes) aumentavam durante a diferenciação (Stadler et al., 2010). Enquanto os miRNAs com expressão aumentada durante a diferenciação estariam envolvidos com a inibição do programa transcricional relacionado à pluripotência e auto-renovação das CTE, os miRNAs com expressão diminuída durante a diferenciação estariam envolvidos com a liberação do programa transcricional das células diferenciadas. A figura 05 descreve alguns exemplos de 
miRNAs expressos diferencialmente, dependendo do estado de diferenciação em que a células se encontra.

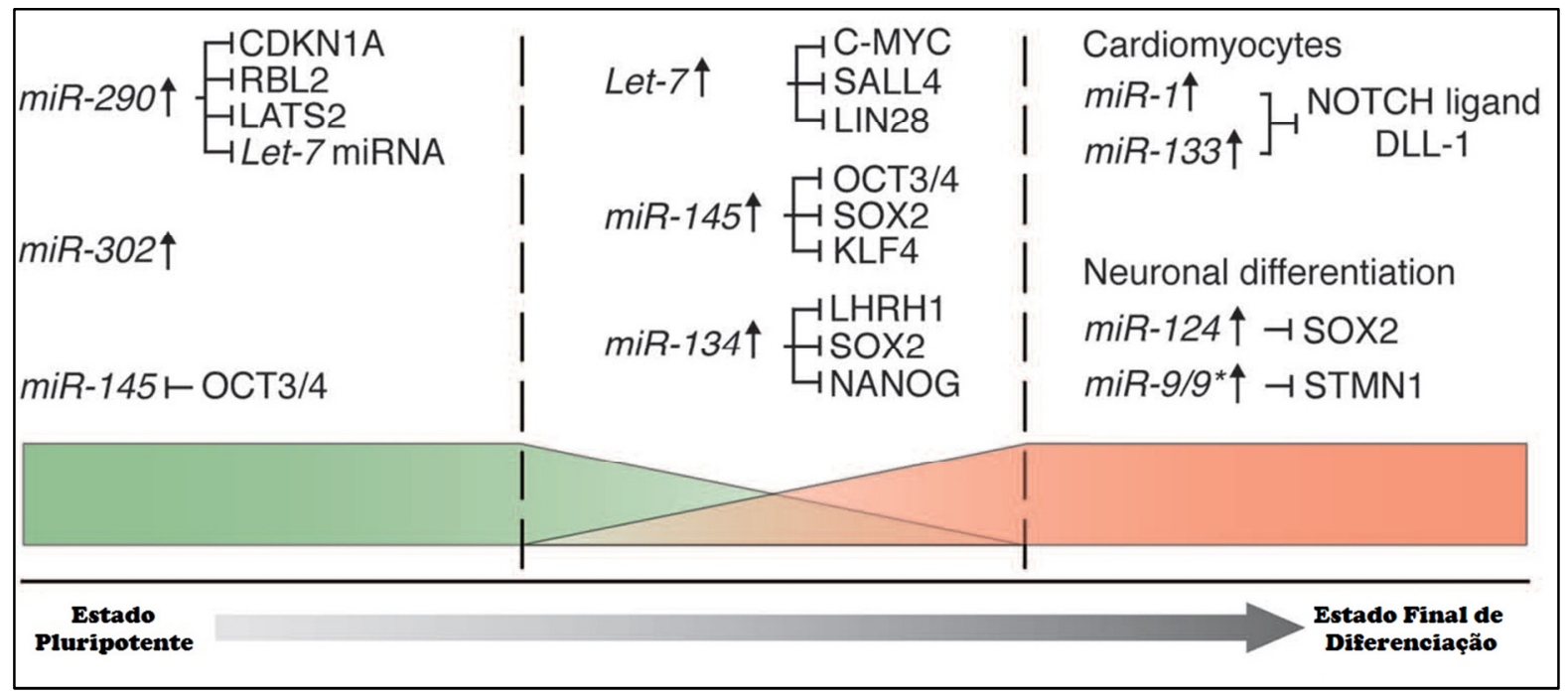

Figura 5 microRNAs expressos diferencialmente de acordo com o grau de diferenciação celular. Enquanto miRNAs como miR-290 e miR-302 encontram-se elevados em células pluripotentes, outros miRNAs como Let-7, miR-145 e miR-124 só começam a ser expressos quando as células se encontram mais diferenciadas. Fonte: Tollervey e Lunyak (2012).

\subsection{Células de Carcinoma Embrionário como Modelo para o Estudo das CTE}

Os teratocarcinomas são tumores que apresentam elementos dos três folhetos embrionários e, além de células diferenciadas, também apresentam células malignas indiferenciadas, conhecidas como células de carcinoma embrionário (CCE), o que diferencia os teratocarcinomas dos teratomas, pois estes são tumores benignos e compostos somente de células diferenciadas (Andrews, 2002; Barbaric e Harrison, 2012; Stevens e Varnum, 1974).

Além de sua ocorrência natural, foi descoberto que a indução de teratocarcinomas era possível por meio da transferência de embriões nas fases iniciais da embriogênese para sítios ectópicos (Solter, Dominis e Damjanov, 1979; Solter, Skreb e Damjanov, 1970). O estudo da biologia das CCE, derivadas de teratocarcinomas, se tornou possível com a geração de linhagens celulares que podiam ser cultivadas in vitro (Finch e Ephrussi, 1967; Kahan e Ephrussi, 1970). Essas linhagens mantinham suas características de pluripotência, se 
mantendo indiferenciadas em cultura por longos períodos de tempo e mantendo também a capacidade de gerar teratocarcinomas quando retransplantadas em animais.

Vários estudos comprovaram que as CCE possuem várias características de CTE e, seguindo este pensamento, foram desenvolvidos experimentos nos quais CCE de camundongos foram implantadas em blastocistos de camundongos e essas células acabaram contribuindo para o desenvolvimento de tecidos normais do feto, gerando um animal normal quimérico (Brinster, 1974; Mintz e Illmensee, 1975) (Fig. 06).

Algumas características imunofenotípicas das CCE humanas são: a expressão dos antígenos SSEA-3 (stage-specific embryonic antigen-3) e SSEA-4 (stage-specific embryonic antigen-4) como também das proteínas TRA-1-60, TRA-1-81 e TRA-2-49; e a ausência de expressão de SSEA-1 (stage-specific embryonic antigen-1)(Andrews et al., 1982, 1984, 1984; Badcock et al., 1999). Essas características fenotípicas são as mesmas encontradas nas CTE humanas (Draper et al., 2002). Tendo em vista a grande similaridade entre CCE e CTE, as linhagens de CCE são amplamente utilizadas como modelos experimentais para estudos in vitro das CTE (Andrews, 2002; Andrews et al., 2005; Greber, Lehrach e Adjaye, 2007; Stewart et al., 2008). 


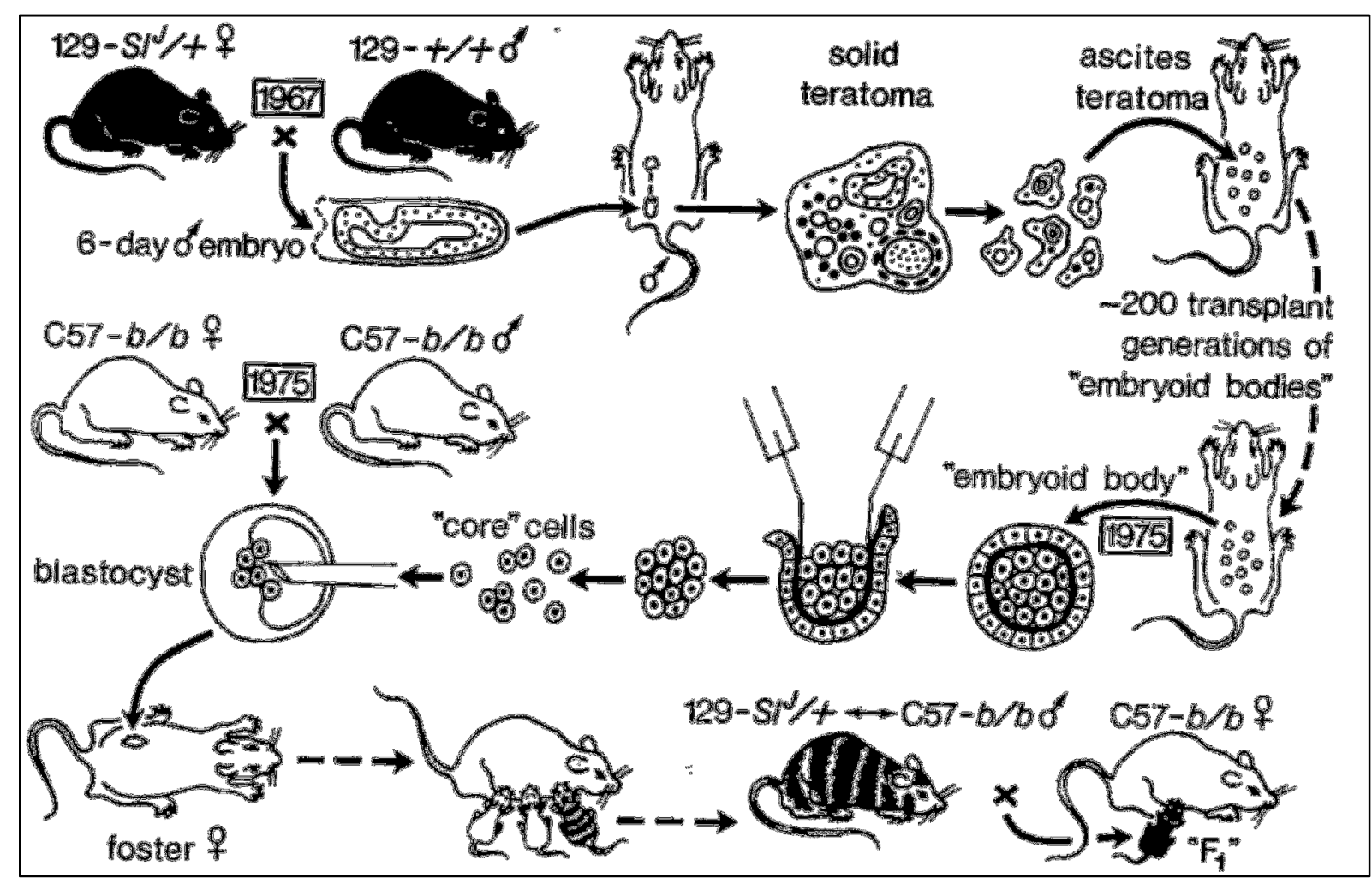

Figura 6 Representação histórica dos experimentos realizados para entendimento das características e biologia de células de carcinoma embrionário (CCE). Iniciando-se da parte superior esquerda, foi gerado um teratoma a partir de um embrião ("F1") cromossomicamente macho (XY) da linhagem 129 de pais agouti pretos. Esse embrião foi implantado em outro animal e gerou um tumor metastático no nódulo renal. O tumor primário foi transplantado intraperitonialmente, gerando um tumor ascítico de corpos embrióides. Após alguns anos, as CCE obtidas dos corpos embrióides foram implantadas em blastocistos gerados de pais não-agouti e transferidos para uma "barriga de aluguel". Como resultado, foram obtidos camundongos normais com mosaicismo na pelagem (listrados) e/ou contribuições teciduais internas das células de CCE. Um macho mosaico adulto foi cruzado com fêmeas marrons e gerou prole semelhantes à "F1", provando a presença de espermas normais de células de teratocarcinoma. Fonte da imagem: Mintz and Illmensee (1975).

Uma CCE humana muito utilizada no meio científico, a NTera-2 cl.D1 (NTera-2), é uma sub-linhagem clonal da linhagem Tera2. Para a obtenção dessa sub-linhagem, a Tera2 foi implantada em camundongos nude. As células obtidas do tumor gerado nos camundongos pareceram manter suas características de CCE quando em cultura (Andrews et al., 1984). Uma das vantagens do uso da NTera-2 é que, para seu cultivo in vitro, não é necessário o uso de células feeder e esta linhagem possui a capacidade de diferenciar-se em células provenientes dos três folhetos embrionários (Pal e Ravindran, 2006) e responde indutores de diferenciação celular, tais como o ácido retinóico (Andrews, 1984), HMBA (hexamethylene 
bisacetamide) (Andrews et al., 1990) e proteínas morfogênicas ósseas (bone morphogenetic proteins, BMP) (Andrews et al., 1994).

As células da linhagem NTera-2, quando submetidas ao tratamento com ácido retinóico, sofrem modificações no seu perfil fenotípico, perdendo a expressão de fatores relacionados à seu estado pluripotente e iniciando a expressão de marcadores neurais, chegando até a produzir neurônios funcionais (Andrews, 1984; Shahhoseini et al., 2010; Zeller e Strauss, 1995).

Quando tratadas com HMBA ou BPM, as células da linhagem NTera-2 apresentam um padrão de diferenciação distinta daquele observado em células submetidas ao tratamento com ácido retinóico, pois são observados poucos neurônios evidentes e algumas células passam a expressar marcadores de tecido não-nervoso, como a actina de músculo liso (Andrews et al., 1990, 1994).

\subsection{High-Throughput Screening e High-Content Screening}

High-Throughput Screening (HTS) é um método de experimentação científica utilizado principalmente na indústria farmacêutica e de grande interesse no campo da biologia, pois permite uma realização de testes com um grande número de moléculas diferentes, fornecendo análises rápidas e com um grande número de dados. O uso de HTS permite uma identificação rápida de moléculas que possam modular diferentes vias dentro do universo celular (Hann e Oprea, 2004; Zhang et al., 2008).

Tendo em vista que este tipo de método permite a obtenção de um vasto número de dados e também o estudo de vários possíveis moduladores de determinadas vias de interesses, o uso de linhagens repórteres que permitam o estudo de vias relacionadas ao estado pluripotentes das CT se mostra uma ferramenta de grande valia. O uso da luciferase como repórter para estudos de expressão gênica, avaliação da atividade de fatores de transcrição específicos ou outros, tem sido amplamente realizado em diferentes áreas da biologia (Aoki et 
al., 2000; Kuroda et al., 2013; Su et al., 2011; Yao et al., 2010). Por esta razão, no presente trabalho, foi realizada a tentativa de geração de linhagens repórteres para a atividade de FT relacionados ao fenótipo pluripotente.

Diferente dos métodos de HTS, que se baseiam em sua maioria em análises bioquímicas, os métodos de HCS (ou ainda, High-Content Analysis/Microscopy) se baseiam na aquisição automatizada de imagens de microscopia de fluorescência de células dispostas em placas (de 96, 384, ou até 1536 poços), acoplada ao processamento e análise computacional das imagens; permitindo a avaliação qualitativa e quantitativa de um grande número de condições experimentais, e de forma simultânea. Ainda, a aquisição de dados derivados de grande número de células a partir de poucas imagens de um único poço, permite a utilização de um número reduzido de células por condição experimental, levando a uma redução enorme dos custos (em função do pequeno volume de reagentes utilizados), permitindo um aumento na escala dos screenings. Instrumentos de HCS podem fornecer informações funcionais e morfométricas de células individuais dentro de populações heterogêneas e em momentos diferentes, permitindo que as CT sejam avaliadas dinamicamente (Damoiseaux et al., 2009).

Os instrumentos de HCS podem utilizar diversas combinações de filtros de emissão (excitação) e detecção, permitindo que uma vasta gama de reagentes fluorescentes possa ser detectada simultaneamente. Diferentes corantes fluorescentes, com afinidades por diferentes compartimentos celulares (núcleo, membrana, citosol, organela) e com diferentes propriedades físico-químicas, podem ser utilizados em combinação com reagentes de detecção (anticorpos, proteínas, etc) ligados a fluoróforos diversos, permitindo o desenvolvimento de uma diversidade enorme de ensaios funcionais. O principio básico da análise consiste em demarcar $\mathrm{o}(\mathrm{s})$ compartimento(s) celular(es) de interesse, utilizando corantes lidos em um determinado canal de fluorescência. Estas regiões são identificadas por 
algoritmos que segmentam a imagem, de maneira que o sinal derivado de outros reagentes de detecção (lidos em outro canal) possam ser quantificados exclusivamente nestas regiões. Diferentes avaliações quantitativas e qualitativas podem ser realizadas, envolvendo as diferenças de intensidade entre as regiões analisadas e, também, as alterações morfológicas associadas (Taylor, 2007; Xia e Wong, 2012). 
2. Objetivos 


\subsection{Objetivo Geral}

Estabelecer e caracterizar um modelo experimental, para o estudo de fatores envolvidos na manutenção da pluripotência, auto-renovação e diferenciação celular, utilizando a linhagem celular pluripotente NTera-2.

\subsection{Objetivos Específicos}

- Padronizar o protocolo de diferenciação celular induzida pelo ácido all-trans retinóico (atRA) em células da linhagem NTera-2;

- Avaliar a expressão gênica de fatores relacionados à pluripotência (Oct4 e Nanog) ou Transição Epitelio-Mesenquimal - EMT (N-caderina), durante a indução de diferenciação celular;

- Avaliar o efeito do atRA sobre a proliferação celular destas células.Estabelecer linhagens repórteres

- Padronizar e estabelecer um método para o estudo do efeito do tratamento com atRA sobre a expressão protéica dos fatores Oct4 e Nanog, durante a diferenciação celular, por meio da análises de imunofluorescencia baseadas em um sistema de High-Content Screening (HCS); 


\subsection{Cultura celular e condições de cultivo}

Para o desenvolvimento do presente estudo, foi utilizada uma linhagem celular de carcinoma embrionário humano (NTera-2). Esta linhagem foi gentilmente cedida pela $\operatorname{Dr}^{\mathrm{a}}$. Luciana Morganti Ferreira Maselli, do Laboratório de Genética e Hematologia Molecular da USP de São Paulo - SP.

A linhagem celular NTera-2 encontrava-se estocada em solução de congelamento (70\% high glucose Dulbecco's Modified Eagle's Medium (DMEM), 20\% soro bovino fetal (SBF), 10\% DMSO), em nitrogênio líquido $\left(-196^{\circ} \mathrm{C}\right)$. Para a realização dos experimentos, as células foram descongeladas em meio de cultura completo (DMEM, complementado com 10\% de $\mathrm{SBF}, 50 \mathrm{U} / \mathrm{mL}$ de penicilina e $50 \mu \mathrm{g} / \mathrm{mL}$ estreptomicina). Inicialmente, as células que se encontravam na solução de congelamento $(1 \mathrm{~mL})$ foram transferidas para um tubo de centrífuga de $15 \mathrm{~mL}$, contendo um volume de $10 \mathrm{~mL}$ de meio de cultura. Em seguida, foram submetidas à centrifugação (10 minutos, $\left.1200 \mathrm{rpm}, 25^{\circ} \mathrm{C}\right)$. O sobrenadante resultante foi então desprezado e o pellet de células foi ressuspenso em $1 \mathrm{~mL}$ de meio de cultura e a suspensão celular foi então transferida para um garrafa de cultivo celular de $25 \mathrm{~cm}^{3}$, contendo $5 \mathrm{~mL}$ de meio de cultura completo. As células foram então incubadas $\left(37^{\circ} \mathrm{C}, 5 \% \mathrm{CO}_{2}\right.$ e $85 \%$ de umidade do ar) até a próxima troca de meio.

Para a manutenção do cultivo celular, o meio de cultura foi trocado a cada dois dias e as células foram repicadas ao atigirem uma confluência celular em volta de $90 \%$. O repique foi realizado com um método físico, utilizando-se cell scrapers, já que o uso de tripsina induz a diferenciação celular desta linhagem, o que inviabilizaria o uso da mesma para estudos posteriores. Sendo assim, o meio de cultura antigo foi então retirado, em seguida as culturas foram lavadas com $5 \mathrm{~mL}$ de PBS (1X). Após a lavagem das células, foram adicionados mais 5 $\mathrm{mL}$ de PBS e as células foram mecanicamente removidas da garrafa com o uso de um cell scraper. A suspensão celular foi então transferida para um tubo de centrífuga e submetida 
centrifugação, como citado anteriormente. O sobrenadante foi descartado e as células foram redistribuídas em novas garrafas de cultivo.

\subsection{Ensaio da Luciferase}

\subsubsection{Geração de Linhagens Repórteres Estáveis}

Para a geração de linhagens celulares repórteres estáveis, foram utilizadas partículas lentivirais com vetores contendo um gene repórter da enzima Firefly-luciferase sob controle de regiões promotoras ligantes dos fatores de transcrição Oct4 (CLS-7025L-1), Nanog (CLS4037L-1) e RAR (Receptor do Acido Retinóico, CLS-016L-1) (Cignal ${ }^{\mathrm{TM}}$ Lenti Reporter, SABiosciences - QIAGEN, Hilden, Alemanha). Uma representação da construção dessas partículas lentiviaris se encontra na Figura 7.

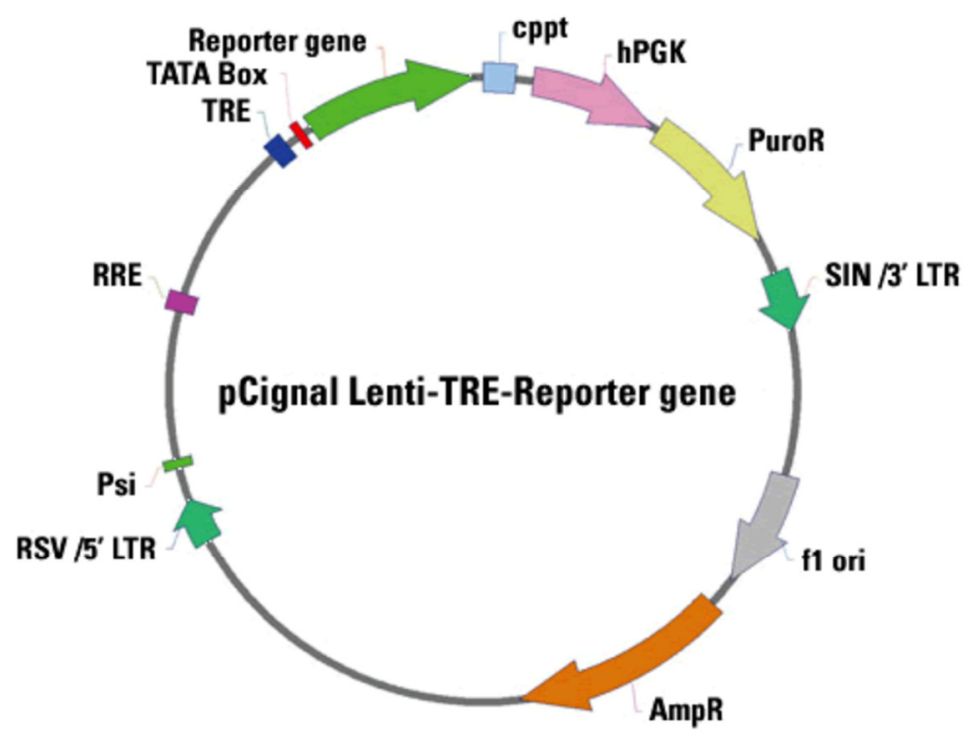

Figura 7 Esquema representativo do vetor lentiviral utilizado para a geração do vírus Cignal Lenti Reporters, os quais transmitem à célula a característica de produzir um determinado gene repórter (no presenta caso a luciferase) em resposta à presença de um fator de transcrição (ex.: Oct4, Nanog e RAR). Fonte: Cignal $^{\mathrm{TM}}$ Lenti Reporters User Manual

Em suma, para a geração das linhagens repórteres, as células da linhagem NTera-2 foram retiradas mecanicamente de garrafas de cultura e ressuspendidas em meio de cultura completo, numa densidade celular de $2 \times 10^{2}$ células $/ \mu \mathrm{L}$. Em seguida, $100 \mu \mathrm{L}$ desta suspensão 
celular $\left(2 \times 10^{4}\right.$ células) foram aplicados em poços de placas de 96 poços brancas (BD, Franklin Lakes, NJ, Estados Unidos da América) e as mesmas foram então incubadas.

No dia seguinte, o meio de cultura foi substituído por $50 \mu \mathrm{L}$ de meio de cultura contendo partículas lentivirais (inicialmente o controle CMV-Renilla), numa concentração de 3,0 MOI (Multiplicity of Infection). A placa então foi incubada por um período de 20 horas e após este tempo, o meio contendo as partículas lentivirais foi retirado e substituído por $100 \mu 1$ de meio de crescimento fresco, e a placa foi incubada por 48 horas.

Passadas as 48 horas, o meio de crescimento foi substituído por um meio de cultura contendo uma quantidade adequada de antibiótico (Higromicina: $150 \mu \mathrm{g} / \mathrm{mL}$ ou Puromicina: $1 \mu \mathrm{g} / \mathrm{mL}$ ) para a seleção das células transduzidas. O meio contendo o antibiótico foi substituído a cada 2 dias e as células resistentes foram transferidas para uma placa de 24 poços, até alcançarem confluência suficiente para serem novamente transferidas para uma placa agora de 6 poços e depois para um frasco de cultura de $75 \mathrm{~cm}^{3}$. Essas células foram então submetidas ao congelamento para a geração de estoque.

\subsubsection{Transdução Transiente dos Vetores Repórteres}

Para a realização do ensaio da luciferase de forma transiente, $100 \mu \mathrm{L}$ de uma suspenção de células NTera2, contendo um total de $2 \times 10^{4}$ células, foram transferidas para placas brancas de 96 poços $(\mathrm{BD})$ e em seguida incubadas pro 24 horas. Após este período de incubação, o meio de cultura foi substituído por um novo meio contendo as partículas lentivirais de expressão constitutiva de Renilla-Luciferase (1,5 MOI) e de repórteres para Oct4 ou Nanog (1,5 MOI) e as células foram incubadas por 48 horas para que então fosse realizada a avaliação da atividade da luciferase. O esquema para o ensaio transiente se encontra apresentado na Figura 08. 
Como controle negativo para a expressão dos fatores de pluripotência Oct4 e Nanog, o mesmo ensaio foi desenvolvido em uma linhagem de fibroblastos humanos, a linhagem BJ.

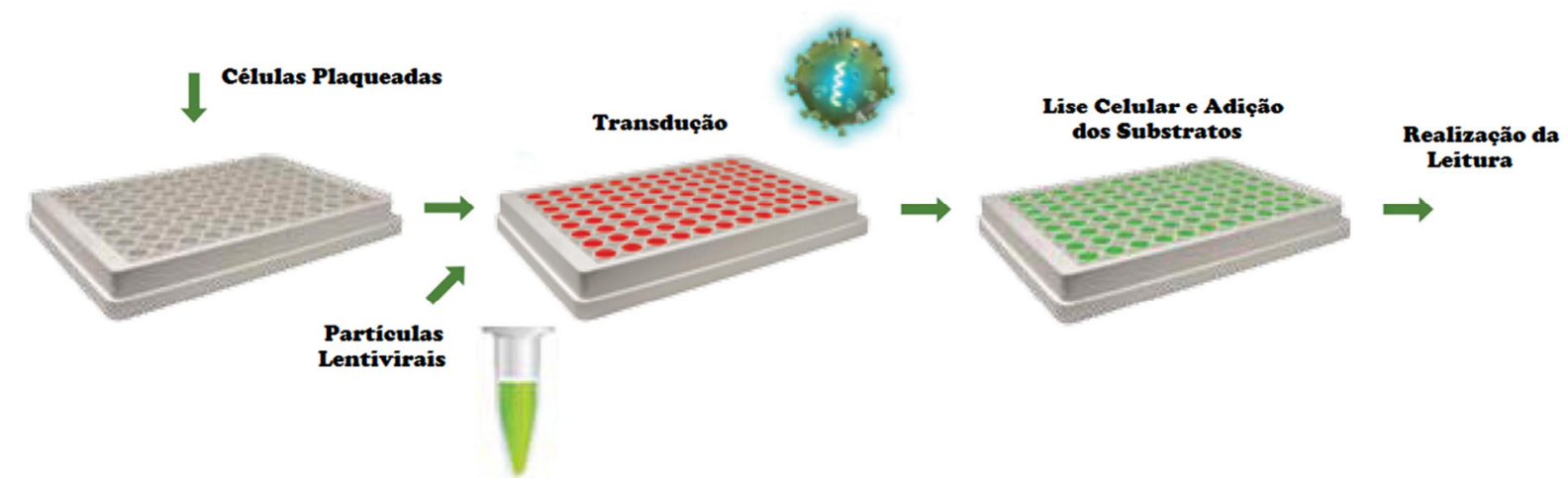

Figura 8 Esquematização da realização do Ensaio da Luciferase, de maneira transiente, em células NTera-2 e BJ.

\subsubsection{Avaliação da Atividade da Luciferase.}

A ativação da transcrição das diferentes construções com gene repórter foi avaliada com o kit Dual-Glo Luciferase Assay System (Promega, Fitchburg, WI, Estados Unidos da América), de acordo com as instruções do fabricante. Em suma, este reagente induz a lise celular e atua como um substrato para a enzima Firefly-luciferase produzindo um sinal luminescente estável (60\% do sinal após duas horas). A adição do reagente Dual-Glo Stop \&Glo bloqueia a luminescência resultante da reação Firefly-luciferase (cerca de 10 mil vezes) e fornece um substrato para a enzima Renila-luciferase, gerando um sinal luminescente que pode ser mensurado. Os resultados foram obtidos em um luminômetro de microplaca Centro LB 960 (Berthold Technologies, Bad Wildbad, BW, Alemanha). Os valores de intensidade de luminescência (IL) obtidos foram então normalizados realizando-se uma razão entre a IL de firefly-luciferase e de Renilla-luciferase.

\subsection{Indução de Diferenciação Celular}

Para a indução de diferenciação celular, foi o utilizado o ácido trans-retinóico (all trans-retinoic acid, atRA; Sigma-Aldrich, Steinhein, Alemanha). A concentração de $10 \mu \mathrm{M}$ 
foi baseada no trabalho de Deb-Rinker e colaboradores(2005). O esquema apresentado na Figura 09 representa o protocolo de indução de diferenciação, o qual foi utilizado nos diferentes experimentos realizados no presente trabalho.

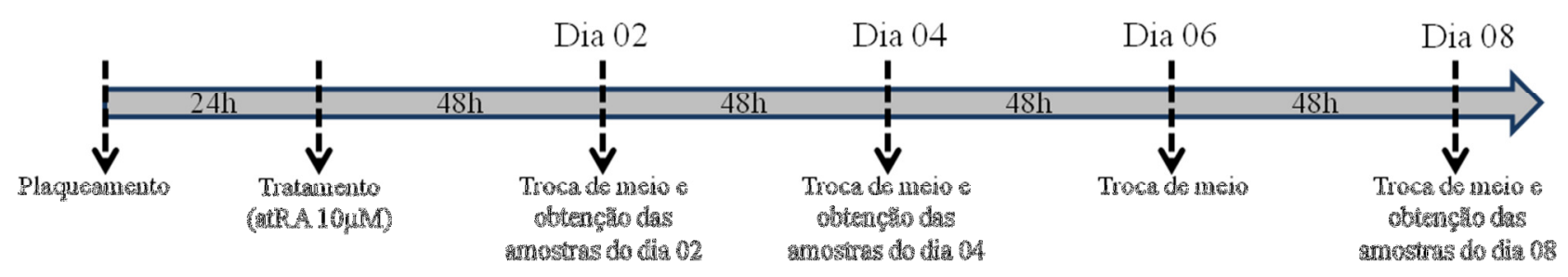

Figura 9 Esquema representativo do protocolo de indução de diferenciação celular, utilizado para os diferentes estudos do presente trabalho. Nele encontram-se descritos os tempos de tratamentos, renovação do meio de cultura (com ou sem atRA) e os momentos em que foram realizadas as obtenções de amostras para a realização dos experimentos independentes, os quais encontram-se descritos posteriormente.

Para uma melhor observação dos efeitos do tratamento com atRA sobre a diferenciação celular da NTera-2, foram montados dois diferentes grupos, sendo estes o grupo controle, o qual não foi submetido à indução de diferenciação celular, e o grupo tratado com atRA. Além disso, foi feita uma observação temporal para permitir uma melhor visualização da diferenciação celular induzida pelo atRA com o tempo e também o comportamento das células, tratadas e não tratadas, durante um maior período de tempo em cultura. Sendo assim, os grupos foram subdivididos de acordo com a presença ou ausência de tratamento com atRA e o tempo em que as células permaneceram em cultivo após a primeira troca de meio de cultura (24 horas após o plaqueamento).

Foram escolhidos três pontos na linha do tempo de tratamentos para se fazer as análises, sendo estes os segundo, quarto e oitavo dias após a primeira troca de meio. O grupo tratado com atRA continuou sob tratamento durante todos os oito dias de cultivo.

\subsection{Extração de RNA}

Para a obtenção do RNA das culturas de NTera-2 tratadas ou não com atRA, inicialmente foram plaqueadas $1 \times 10^{6}$ células em placas de 6 poços. Após o período de $24 \mathrm{~h}$, o 
meio de cultura foi retirado e substituído por um meio contendo $10 \mu \mathrm{M}$ de atRA (para o grupo tratado) ou por um meio novo, sem atRA (para o grupo controle). A partir desta troca de meio, foram colhidas amostras de células nos segundo, quarto e oitavo dias seguintes. Cada amostra foi devidamente identificada como Ctrl D2, Ctrl D4 e Ctrl D8, para as amostras do grupo controle colhidas dois, quatro e oito dias após a primeira troca do meio de cultura, respectivamente; e atRA D2, atRA D4, atRA D8, para aquelas amostras do grupo tratado, colhidas dois, quatro e oito dias após o primeiro tratamento.

As amostras de células dos diferentes grupos de tratamentos, nos diferentes tempos, depois de colhidas das placas por tripsinização, seguida de inativação com DMEM completo e lavadas com PBS (1X), foram ressuspensas em $250 \mu 1$ de PBS (1X) com DEPC (Dietilpirocarbonato; Sigma-Aldrich) e $750 \mu 1$ de TRIZOL (solução monofásica de fenol e isotiocianato de guanidina - Invitrogen, Carlsbad, CA, USA). Em seguida, foram transferidas e mantidas em freezer a $-80^{\circ} \mathrm{C}$ para posterior extração de RNA, em microtubos de $2 \mathrm{~mL}$, até a realização da extração do RNA.

Para a extração do RNA total das células, as amostras foram descongeladas e a cada uma foi adicionado os volumes de $10 \mu \mathrm{L}$ de glicogênio e $200 \mu \mathrm{L}$ de clorofórmio. As amostras foram entãohomogeneizadas em vortex e, em seguida, centrifugadas(14000 rpm por 15 minutos a $4^{\circ} \mathrm{C}$ ). Após a centrifugação, foram retirados cuidadosamente os anéis formados em cada amostra, transferindo-os a outros tubos e nestes foram adicionamos $500 \mu \mathrm{L}$ de isopropanol gelado. As amostras foram deixadas em descanso para que o material precipitasse, em temperatura ambiente, por 15 minutos. Seguido deste período, o material foi centrifugado novamente, nas mesmas condições citadas anteriormente, e então o sobrenadante foi descartado. O pellet formado foi ressuspenso em etanol $70 \%$ e, em seguida, o material foi submetido a mais um round de centrifugação. O sobrenadante foi descartado e o pellet foi 
ressuspenso em $15 \mu$ de água livre de RNAse. As amostras de RNA obtidas foram congeladas em freezer $-80^{\circ} \mathrm{C}$.

O RNA total obtido das amostras foi quantificado por espctofotometria em um aparelho Nanovue Plus (General Eletronics, Little Chalfont, BKM, Reino Unido) no comprimento de onda de $260 \mathrm{~nm}$, utilizando equivalência de $40 \mu \mathrm{g} / \mathrm{ml}$ para 1 unidade de absorbância. O grau de pureza das amostras foi avaliado através da razão 260/280 nm, sendo considerada uma boa extração aquela que apresentou valores entre 1,6 e 1,8.

\subsection{Transcrição Reversa}

Parte do RNA extraído $(1 \mu \mathrm{g})$ de cada amostra foi empregado na síntese do cDNA, realizada por transcrição reversa a partirdo High Capacity cDNA Archive Kit (Applied Biosystems, Foster City, CA, Estados Unidos da América), seguindo as instruções do fabricante. As amostras de cDNA resultantes desta reação foram diluídas para uma concentração final de $10 \mathrm{ng} / \mu \mathrm{L}$ em água livre de nucleases (Promega, Madison, WI, Estados Unidos da América), para então serem utilizadas nas análises de expressão gênica.

\subsection{Análises de Expressão Gênica (mRNA)}

Para os estudos de expressão gênica, foram analisados os transcritos dos genes Oct4, Nanog, N-caderina e GAPDH, por meio de PCR em tempo real, por meio do uso de SYBR Green. Os primers utilizados foram desenhados com o uso da ferramenta eletrônica da Integrated DNA Technologies (IDT; www.idtdna.com) e a sequências destes encontra-se descrita na Tabela 01. 
Tabela 1 Lista contendo os primers utilizados para as reações de PCR em tempo real, as sequências dos primers fowerd e reverse de cada transcrito e a concentração de cada um nas reações.

\begin{tabular}{clc}
\hline Primer & \multicolumn{1}{c}{ Sequência } & Concentração na Reação \\
\hline \multirow{2}{*}{ Oct4 } & F: AGTGAGAGGCAACCTGGAGA & $0,4 \mu \mathrm{M}$ \\
& R: CAAAAACCCTGGCACAAACT & $0,4 \mu \mathrm{M}$ \\
Nanog & F: CAAAGGCAAACAACCCACTT & $0,4 \mu \mathrm{M}$ \\
& R: ATTGTTCCAGGTCTGGTTGC & $0,4 \mu \mathrm{M}$ \\
N-caderina & F: CCCACACCCTGGAGACATTG & $0,4 \mu \mathrm{M}$ \\
& R: GCCGCTTTAAGGCCCTCA & $0,4 \mu \mathrm{M}$ \\
GAPDH & F: GAAGGTGAAGGTCGGAGTC & $0,4 \mu \mathrm{M}$ \\
& R: GAAGATGGTGATGGGATTTC & $0,4 \mu \mathrm{M}$ \\
\hline
\end{tabular}

As reações de PCR em tempo real foram realizadas em duplicata, para cada amostra, utilizando-se os primers específicos de cada transcrito estudado, o reagente Power $S Y B R^{\circledR}$ Green (Applied Biosystems) e as amostras de cDNA (20 ng/reação), em um aparelho 7300 Real Time PCR System (Applied Biosystems). As condições de termociclagem compreenderam uma incubação de $50^{\circ} \mathrm{C}$ por 2 minutos, em seguida $95^{\circ} \mathrm{C}$ por 10 minutos (para ativação da DNA polimerase), e por fim 40 ciclos de $95^{\circ} \mathrm{C}$ por 15 segundos (desnaturação) e $60^{\circ} \mathrm{C}$ por 1 minuto (anelamento e extensão simultâneos). Também foi adicionada uma curva de dissociação ao final para a identificação de possíveis dímeros de primers ou produtos inespecíficos formados durante a reação.

Os resultados foram avaliados através do software Sequence Detection System V1.3 para obtenção dos valores de CT. Os dados obtidos foram então exportados para planilhas do Microsoft Excel, onde foram realizados os cálculos matemáticos para as análises dos dados, da seguinte forma: os valores de Ct de cada transcrito foram normalizados para cada amostra, 
subtraindo-se o valor do Ct obtido para o controle endógeno (GAPDH), obtendo-se assim os valores de $\Delta$ Ct. Após a obtenção destes valores, foram realizados os cálculos para determinação da expressão relativa baseados na fórmula $2^{-\Delta \Delta C t}$ (Pfaffl, 2001), utilizando-se a comparação entre o nível de expressão dos transcritos (fold change) entre os grupos controle e tratados com atRA, nos diferentes tempos de tratamento, como também as variações do nível de expressão com o passar do tempo de cultura celular.

\subsection{Análises de imunofluorescência - High Content Screening (HCS)}

O ensaio de imunofluorescência foi realizado em placas de 96 poços específicas (BD) e as imagens foram obtidas em um aparelho de High Content Screening (HCS), o Operetta (PerkinElmer, Waltham, MA, Estados Unidos da América). Para isso, foram plaqueadas inicialmente $1 \times 10^{4}$ células/poço e $24 \mathrm{~h}$ após o plaqueamento foi realizada a troca do meio de cultura com ou sem atRA. As trocas de meio obedeceram ao esquema apresentado anteriormente (Figura 09).

Nos períodos de obtenção das amostras (2, 4 e 8 dias de cultura), cada placa correspondente ao período de tratamento foi fixada utilizando-se uma solução de formol em PBS (4\% de formol, Sigma-Aldrich), sendo que, para isto, o meio de cultura, contendo ou não atRA, foi retirado e em seguida os poços foram lavados com PBS (1X). Depois de lavados, foram acrescentados $100 \mu \mathrm{L}$ da solução de formol $4 \%$ em cada poço e as placas foram incubadas por 10 minutos em temperatura ambiente. Passado o período de fixação, a solução de formol foi retirada, os poços foram novamente lavados com PBS e, por último, foram adicionados $100 \mu \mathrm{L}$ de PBS (1X) em cada poço, as placas foram embaladas em papel alumínio e armazenadas em geladeira $\left(4 \sim 8^{\circ} \mathrm{C}\right)$ até a marcação com os anticorpos.

Para a realização da marcação, primeiramente o PBS foi substituído por uma solução de glicina (0,1 M; Sigma-Aldrich) e as placas foram incubadas por 30 minutos. Em seguida, a 
solução de glicina foi retirada, os poços foram novamente lavados com PBS (1X) e então submetidos ao passo de permeabilização com o uso de uma solução de Triton $X(0,3 \%$; Sigma-Aldrich) por 10 minutos. Mais uma vez os poços foram lavados com PBS (1X) para então ser realizado o passo de bloqueio, para impedir marcação inespecífica, utilizando-se PBS/BSA (Bovine Serum Albumin, 1\%; Sigma-Aldrich). As placas foram incubadas por 1h com a solução de bloqueio e então foram marcadas com os anticorpos primários específicos para as proteínas de interesses, os fatores de transcrição Oct4 e Nanog. Os anticorpos (IgG de coelho anti-Oct4 e anti-Nanog, Cell Signaling Technology, Beverly, MA, Estados Unidos da América), diluídos conforme as recomendações do fabricante. As placas foram então encubadas por 1h para a marcação com os anticorpos primários, em seguida os poços foram lavados para então ser realizada a marcação com os anticorpos secundários (anti-IgG de coelho, $10 \mu \mathrm{g} / \mathrm{mL}$; Life Technologies, Carlsbad, CA, Estados Unidos da América), os quais são marcados com o fluoróforo Alexa488 (495/519nm). As placas foram incubadas em ambiente escuro por $1 \mathrm{~h}$ com os anticorpos secundários e também com um marcador de citoesqueleto, a faloidina (1U/poço; Life Technologies) marcada com Texas Red (591/608nm). Após este período, os poços foram novamente lavados, em seguida submetidos à marcação com DAPI (0,3 nM; 358/461nm; Life Technologies) por 5 minutos e, acabado este período de encubação, os poços foram submetidos a mais uma etapa de lavagem, em seguida foram adicionados $100 \mu \mathrm{L}$ de PBS (1X) e as placas foram recobertas com papel alumínio e armazenadas em geladeira $\left(4 \sim 8^{\circ} \mathrm{C}\right)$. A obtenção das imagens foi realizada aproximadamente 16 horas após a marcação. Anteriormente a cada troca de solução ou a cada lavagem, as placas foram submetidas à centrifugação $\left(500 \mathrm{rpm}, 3\right.$ minutos, $\left.4^{\circ} \mathrm{C}\right)$.

As imagens obtidas com o Operetta foram utilizadas para a realização de análises de HCS, com uso do programa Harmony 3.0 (PerkinElmer). Utilizando-se este software, foi feita uma mensuração da intensidade de fluorescência do fluoróforo Alexa488, na área do núcleo, e 
um cálculo de porcentagem de células positivas para o mesmo fluoróforo (Alexa488+). Para isto, foi necessária a realização de uma segmentação para determinação da região nuclear e essa segmentação foi feita por meio do uso de ferramentas do Harmony 3.0, como pode ser visualizado na Figura 10.

Inicialmente, foi utilizada a ferramenta find nuclei e com ela foi possível determinar a região nuclear, utilizando-se as imagens obtidas no canal do DAPI como parâmetro, pois este composto é um marcador específico de ácidos nucleicos. Em seguida, com o uso da mesma ferramenta, foi determinada a região dos núcleos que apresentavam marcação com Alexa488 para que posteriormente pudéssemos obter a porcentagem de núcleos Alexa488+ em comparação com o total de núcleos marcados com DAPI.

Depois da realização das segmentações anteriormente citadas, foram selecionados os tipos de análises que realizaríamos. A média da intensidade de fluorescência de Alexa488 foi determinada pela mensuração da intensidade deste fluoróforo dentro da região nuclear definida pela ferramenta find nuclei com o canal de DAPI como parâmetro e isto foi realizado por meio da ferramenta Calculate Intensity Properties. O cálculo de porcentagem de células Alexa488+ foi realizado observando-se o número de objetos que apresentavam esta marcação em comparação ao número de objetos marcados com DAPI. 
Sequência de Análise - HCS
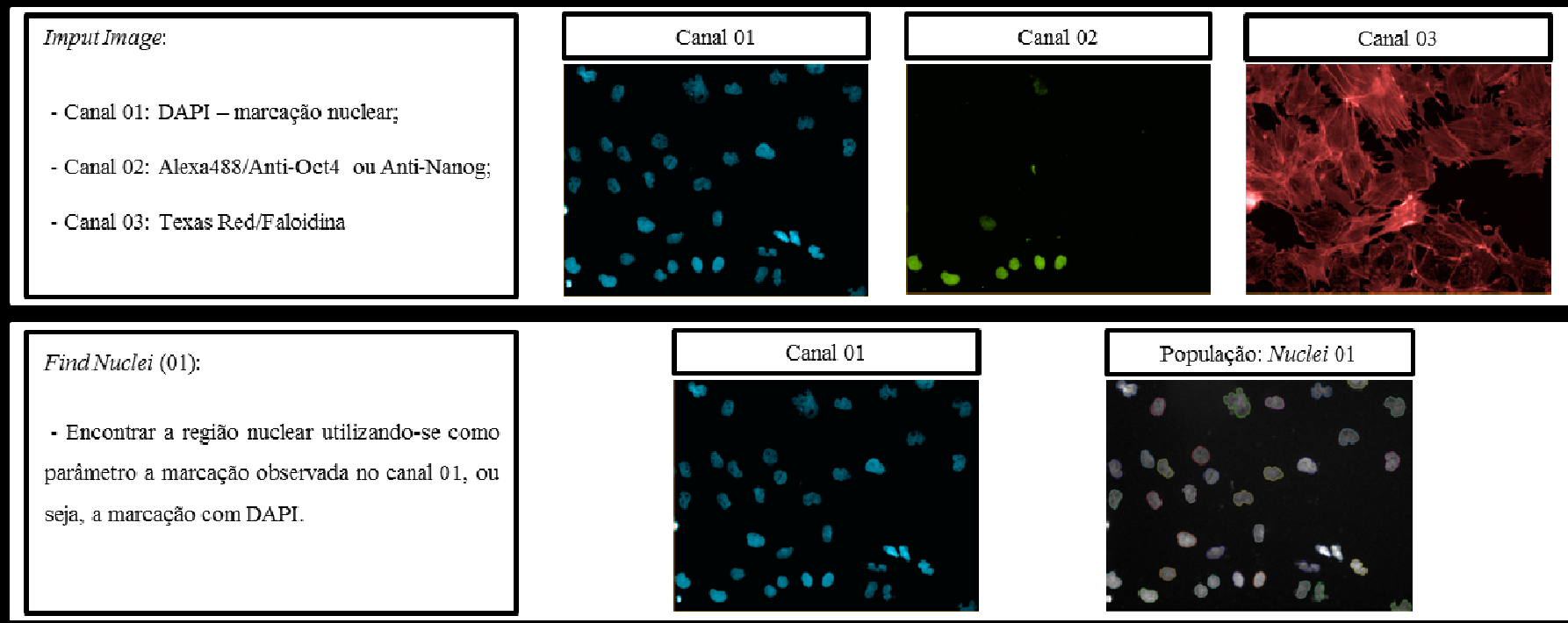

Find Nuclei (02):

Encontrar os núcleos que apresentam a marcação com Alexa488, ou seja, aqueles nos quais encontram-se os fatores de transcrição ativos.

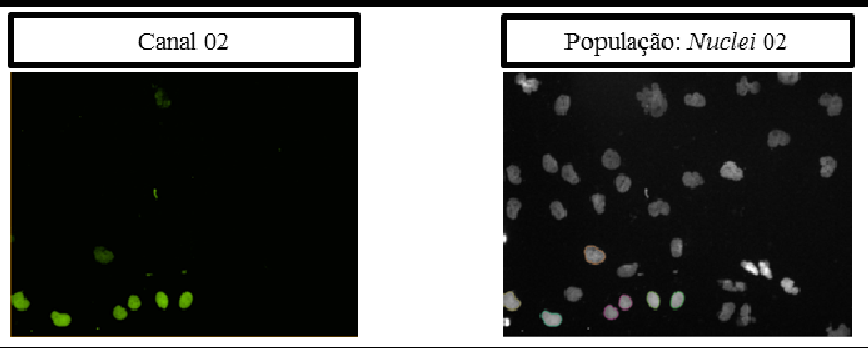

Galculate intensity properties:

- Calcular a intensidade de fluorescência de Alexa488 na região do núcleo, pré-definida na população Nuclei 01 .

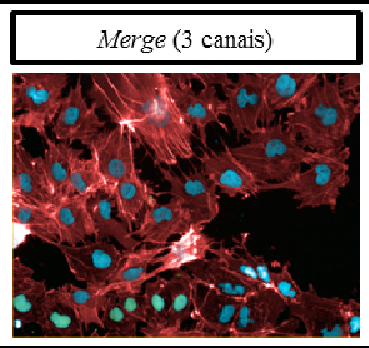

\begin{tabular}{|l|l|}
\hline \multicolumn{2}{|c|}{ População: Nuclei 02 } \\
\hline Object No & $\begin{array}{l}\text { Intensity } \\
\text { Nucleus Alexa } \\
\text { 488 Mean }\end{array}$ \\
\hline 61 & 748.445 \\
\hline 67 & 711.814 \\
\hline 59 & 706.569 \\
\hline
\end{tabular}

Figura 10 Representação do procedimento passo-a-passo utilizado para a realização das análises de imagens, feitas por meio do uso do software Harmony 3.0

\subsection{Ensaio de proliferação celular}

O ensaio do XTT (3-[1-(fenil amino carbonil)-3,4-tetrazólio]-bis(4-metil-6-nitro) ácido benzeno sulfonato sódio hidratado) foi realizado para a avaliação da proliferação celular nos grupos tratados ou não tratados com atRA, nos diferentes tempos de cultura celular, utilizando o Cell Proliferation Kit II (Roche Applied Sciences, Penzberg, OBB, Alemanha). Para isto, 
aproximadamente $1 \times 10^{4}$ células foram plaqueadas em placas de 96 poços translúcidas (Greiner Bio-One Bioscience, Frickenhausen, Germany) e 24h após o plaqueamento foi realizada a troca do meio de cultura com ou sem atRA. As trocas de meio obedeceram ao esquema apresentado anteriormente (Figura 08).

Nos períodos de obtenção das amostras (2, 4 e 8 dias de cultura), cada placa correspondente ao período de tratamento foi retirada de cultura. Os poços foram então lavados com PBS (1X) e foi acrescenta a solução de XTT $(0,3 \mathrm{mg} / \mathrm{mL})$ em meio de cultura completo. A placa foi então recoberta com papel alumínio e incubada por 3 horas, nas mesmas condições utilizadas para o cultivo das células. Após este período, as placas foram levadas para a realização da leitura em um espectofotômetro de escaneamento multiwell, VersaMax (Molecular Devices, Sunnyvale, CA, Estados Unidos da América). Para a obtenção dos valores de absorbância, foram utilizados dois comprimentos de onda, sendo o primeiro capturado pelo sal de formazan $(450 \mathrm{~nm})$ e o segundo não $(650 \mathrm{~nm})$, funcionando como um branco interno de cada poço da placa.

Os valores de absorbância obtidos no primeiro comprimento de onda foram subtraídos pelos valores obtidos no segundo e os valores resultantes foram utilizados na fórmula para determinação da porcentagem (\%) de proliferação celular, a qual encontra-se descrita a seguir:

$\%$ Proliferação Celular $=$ Abs. Tratamento/Abs. Controle x 100

\subsection{Análises estatísticas}

As análises estatísticas foram realizadas através do software GraphPad Prism 5 (GraphPad Software, Inc., San Diego, CA, Estados Unidos da América), utilizando-se do teste ANOVA, combinado com Tukey e os resultados foram considerados estatisticamente significativos quando $\mathrm{p} \leq 0,05$. 
4. Resultados 


\subsection{Ensaio da Luciferase}

\subsubsection{Geração de Linhagens Repórteres Estáveis}

Para a tentativa de obtenção de linhagens repórteres estáveis, inicialmente foram seguidas as informações do fabricante que se encontrava no manual do usuário $\left(\right.$ Cignal $^{\mathrm{TM}}$ Lenti Reporters). Sendo assim, foram realizados testes utilizando-se as concentrações de vírus sugeridas, que partiam de 10 a 50 MOI, mas as células obtidas após os passos de seleção e repiques para recipientes maiores não apresentaram uma morfologia saudável e se tornavam senescentes, como pode ser observado na figura abaixo (Fig. 11):

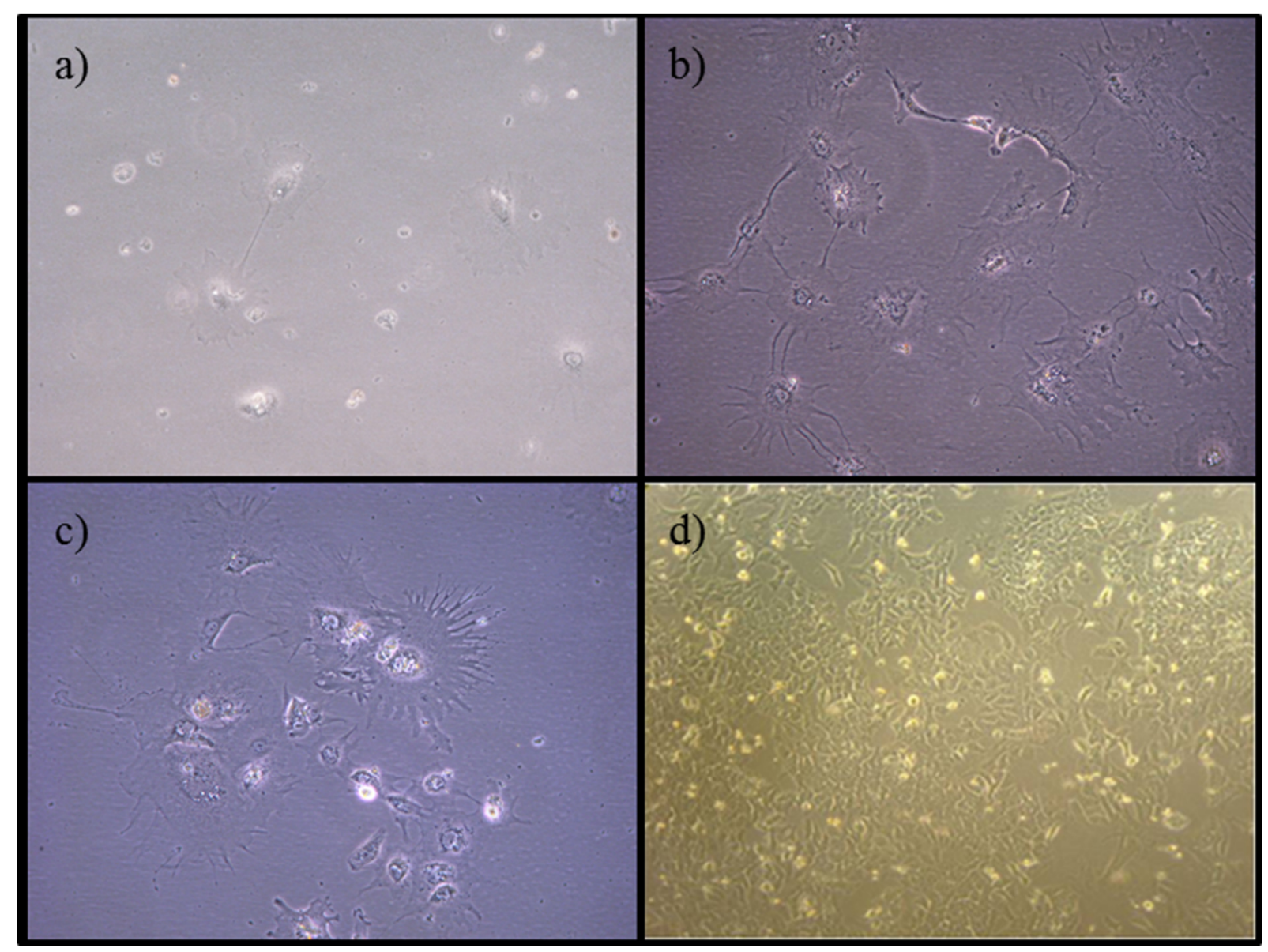

Figura 11 Nesta imagem encontram-se representadas três fotomicrografias (a, b e c) de culturas de células submetidas à transdução com partículas lentivirais e posteriormente selecionadas com antibiótico específico. Essas células apresentam uma morfologia diferente das células saudáveis (d) e perdem seu potencial de proliferação (aumento: 200X). 
Depois de obtidos estes primeiros resultados, foram realizadas diversas modificações no protocolo inicial e, por fim, foi encontrada uma forma de gerar linhagens viáveis, com morfologia saudável e capacidade de proliferação celular semelhante às células não transduzidas, porém essas células não apresentavam atividade do gene repórter, o que nos levou à conclusão de que, de alguma forma, as células possuíam uma capacidade de silenciar o repórter, mantendo somente a expressão do gene de resistência ao antibiótico.

\subsubsection{Ensaios com as Linhagens Repórteres Transientes}

Com a realização do teste transiente para a avaliação da atividade de Oct4 e Nanog na linhagem NTera-2, foi possível comprovar um alto nível de expressão de firefly-luciferase nesta linhagem celular por meio da visualização da intensidade de luminescência (IL) observada nas células transduzidas com os lentivírus portando o repórter para a atividade de Oct4 ou Nanog. A IL para Oct4 apresentou-se 24,2 vezes maior do que na linhagem de fibroblasto humano (BJ), células utilizada como controle negativo, e a IL para Nanog apresentou-se 5,35 vezes maior. Estes resultados podem ser observados na Figura 12.

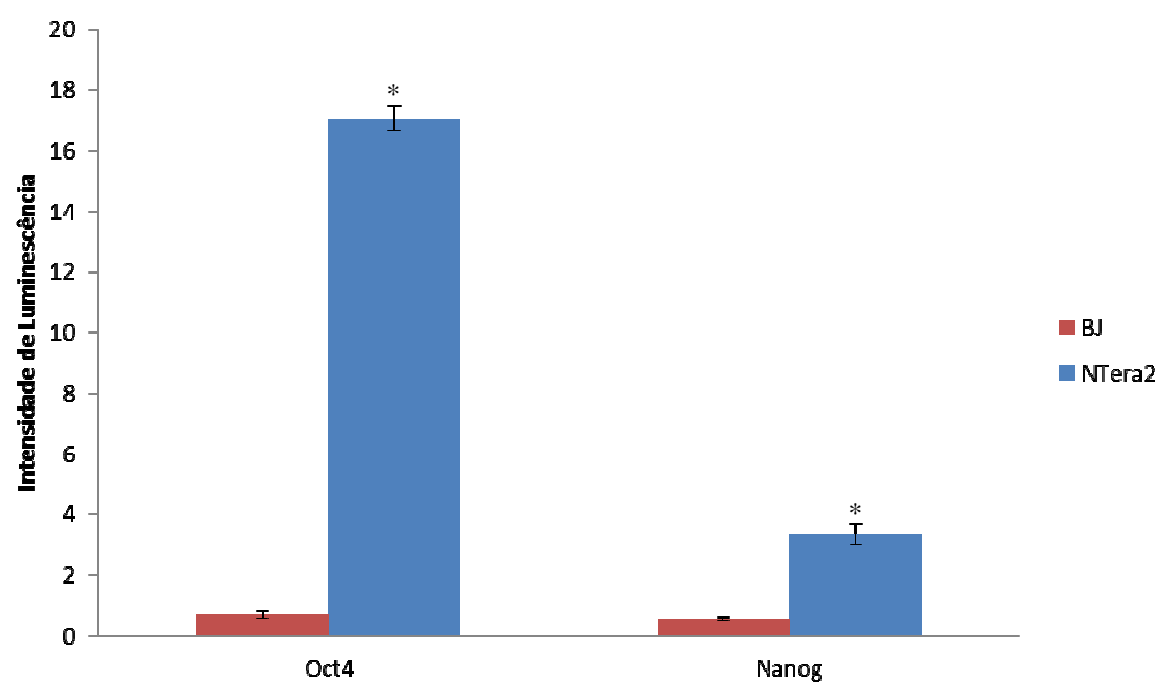

Figura 12 Gráfico apresentado os valores de intensidade de luminescência média e desvio padrão, obtidos das células BJ e NTera2 transduzidas com repórteres para atividade transcricional de Oct4 e Nanog. *diferente do grupo $\mathrm{BJ}(p<0,0001)$. 


\subsection{Expressão Gênica (mRNA)}

Os resultados das análises de expressão gênica dos diferentes transcritos, nos grupos tratados ou não com atRA, encontram-se apresentados de acordo com o tempo de cultura nas Figuras 13 a 16. Pode-se observar que os níveis de expressão de Oct4 (Fig. 13a, 14a e 15a) e Nanog (Fig. 13b, 14b e 15b) se apresentaram diminuídos naquelas culturas tratadas com atRA e todas as diferenças foram estatisticamente significativas $(p<0,0001)$. Já a expressão de NCaderina (Fig. 13c, 14c e 15c) se mostrou aumentada em culturas submetidas ao mesmo tratamento, porém essa diferença só se apresentou estatisticamente significativa $(p<0,05)$ a partir do $4^{\circ}$ dia de tratamento. Estas diferenças citadas foram resultados da comparação entre o nível de expressão de um determinado transcrito em grupo tratado com o seu respectivo controle com o mesmo tempo de cultura celular.

Foi realizada uma segunda forma de análise para se observar a variação da expressão dos transcritos em questão com o passar do tempo de cultura celular. Para isto, o nível de expressão dos transcritos Oct4, Nanog e N-Caderina dos grupos tratado e controle foram comparados com o controle que apresentava menor tempo em cultura celular, o Ctrl D2. Os resultados desta análise se encontram representados na Figura 10, onde podemos observar que os níveis de expressão de Oct4 (Fig. 16a) e Nanog (Fig. 16b) decaem com o passar do tempo nas células em cultura, tanto nas tratadas como nas não tratadas. É importante notar que no $4^{\circ}$ dia, as células tratadas com atRA já possuem níveis de expressão de Oct4 e Nanog quase nulos, diferentemente daquelas não tratadas, e estes níveis se mantém baixos até o $8^{\circ}$ dia de cultura. No grupo controle, a expressão de Oct4 no $8^{\circ}$ dia já não se diferencia mais do grupo tratado com atRA, diferentemente da expressão de Nanog, que ainda se mantém maior que naquelas células submetidas ao tratamento com atRA ( $\mathrm{p}<0,001)$, porém menor que nas células não tratadas com menor tempo em cultura celular $(\mathrm{p}<0,0001)$. 
Também é curioso observar que os níveis de expressão de N-Caderina (Fig. 16c) não variaram com o passar de tempo de cultura das células não tratadas, se mantendo estável durante os 8 dias, porém, nas células tratadas com atRA, a expressão deste transcrito aumentou de acordo com o tempo de tratamento e a diferença entre o menor tempo de tratamento e o maior tempo é estatisticamente significativa $(p<0,0001)$.
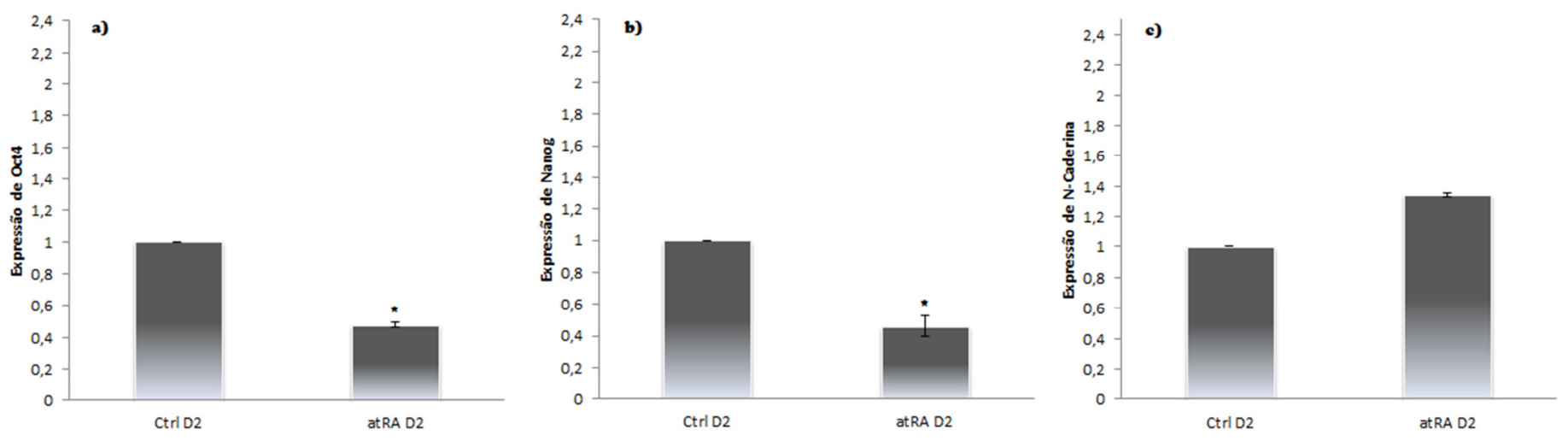

Figura 13 Variação das médias dos níveis de expressão dos transcritos Oct4 (a), Nanog (b) e N-Caderina (c) nos grupos tratado e no controle não tratado com atRA após 2 dias de cultura celular, representada em gráficos. *diferente do grupo controle ( $p<0,0001)$; Ctrl D2: Controle do dia 2; atRA D2: Tratamento com ácido trans-retinóico do dia 2.
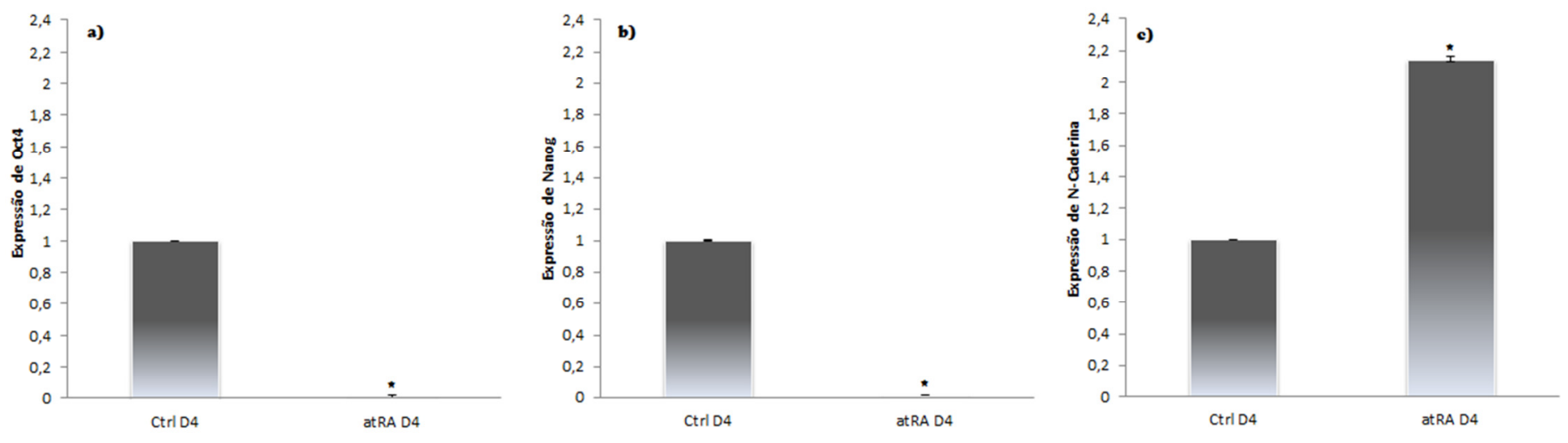

Figura 14 Gráficos representando a variação das médias dos níveis de expressão dos transcritos Oct4 (a), Nanog (b) e N-Caderina (c) nos grupos tratado com atRA e controle após 4 dias de cultura celular. *diferente do grupo controle ( $p<0,0001)$; Ctrl D4: Controle do dia 4; atRA D4: Tratamento com ácido trans-retinóico do dia 4. 

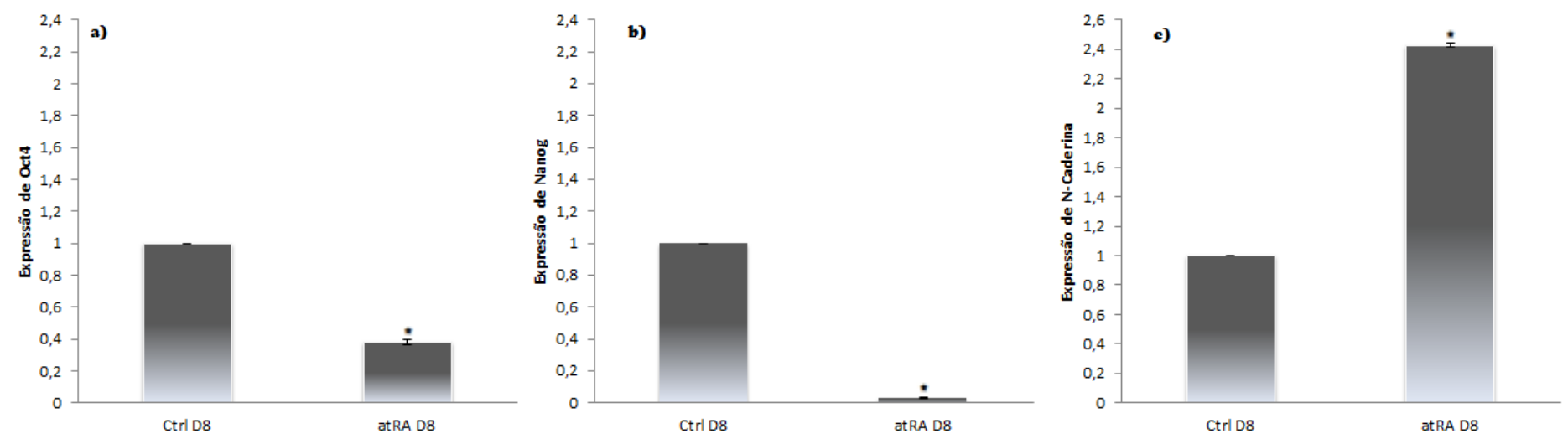

Figura 15 Representação em gráficos das médias dos níveis de expressão dos transcritos Oct4 (a), Nanog (b) e N-Caderina (c) nos grupos tratado e não tratado com atRA após 8 dias de cultura celular. *diferente do grupo controle ( $p<0,0001)$; Ctrl D8: Controle do dia 8; atRA D8: Tratamento com ácido trans-retinóico do dia 8.
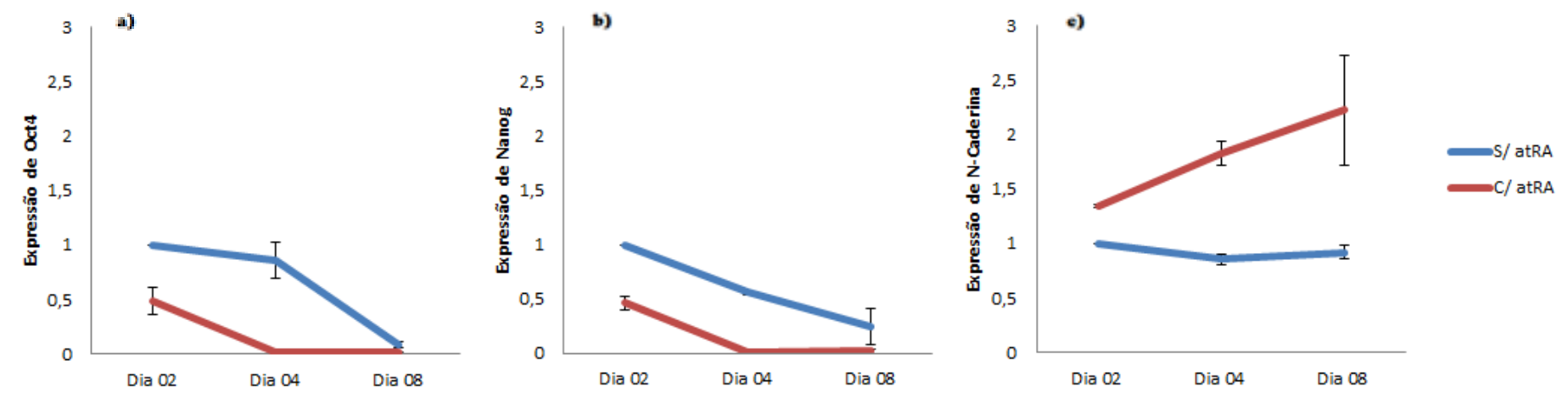

Figura 16 Representação da variação dos níveis de expressão dos transcritos Oct4, Nanog e N-Caderina nos grupos tratado e não tratado com atRA, nos tempos de 2,4 e 8 dias de cultura celular em comparação às células do grupo controle do dia 2.

\subsection{Avaliação por Imunofluorescência em Sistema de HCS}

Para a análise da expressão proteica de Oct4 e Nanog, ambos FT expressos em células com fenótipo pluripotente, foi realizada uma técnica de HCS e as imagens e dados obtidos podem ser visualizadas nas Figuras 17 a 20. Nesta figura encontram-se fotomicrografados alguns campos, afim de se demonstrar a variação da expressão dos fatores de transcrição em culturas de células submetidas ou não ao tratamento com atRA, nos diferentes tempos de cultura celular. 
Como esperado, é possível observar que a marcação de Alexa488, que indica expressão de Oct4 ou Nanog, se encontra localizada no núcleo da célula e isso é observado pela colocalização da marcação de Alexa488 com a marcação de DAPI, um corante específico de ácidos nucleicos.

Quanto à variação da expressão dos fatores de transcrição, nota-se que com dois dias de tratamento com atRA ainda é possível a visualização de células positivas para Oct4 (Fig. 17.A-1 e 17.A-2) e Nanog (Fig. 17.C-1 e 17.C-2), porém nota-se que a marcação é mais intensa naquelas células com mesmo tempo em cultura, porém não tratadas com atRA (Fig. 17.B-1, B-2, D-1 e D-2). Após o período de 4 dias de cultura celular, as células submetidas ao tratamento com atRA já parecem não expressar Oct4 (Fig. 17.E-1, E-2, I-1 e I-2) e Nanog (Fig. 17.G-1, G-2, K-1 e K-2), enquanto nas culturas não tratadas a marcação continua visível. Também é possível notar que, com o maior tempo de cultura celular, ocorre o surgimento de células negativas para Alexa488, o que sugere ausência de Oct4 e Nanog, mesmo em culturas de células não submetidas ao tratamento com atRA. Isso ocorre devido à diferenciação espontânea das células.

Os resultados observados na análise visual corroboraram com os dados obtidos das análises realizadas no software Harmony 3.0 e estes resultados encontram-se em forma de gráficos nas Figuras 18 e 19. Pode-se observar que a intensidade de fluorescência de Alexa488 nos núcleos das células dos grupos tratados com atRA se encontra menor do que naqueles grupos que não foram submetidos ao tratamento com este composto (Fig. 18), e esta intensidade decai com o tempo de tratamento, porém esta diferença não apresentou significância estatística. Também é possível observar que no oitavo dia, a intensidade de fluorescência de Alexa488 se encontra maior no oitavo dia, tanto pra Oct4 quanto para Nanog, no grupo não tratado se comparado com todos os outros grupos tratados ou não com 
atRA $(p<0,0001)$, mas isso pode ter se dado devido ao maior número de células encontrado neste grupo, já que as células continuaram proliferando normalmente.

A porcentagem total de células com núcleo marcado por Alexa488 (Fig. 19) também é maior nos grupos não tratados com atRA do que naqueles tratados, se comparados os controles e tratamentos dos dias consecutivos de cultura, e essa diferença se mostrou estatisticamente significativa $(p<0,001)$. Também é possível visualizar que, naqueles grupos tratados, esta porcentagem vai diminuindo conforme o tempo de tratamento enquanto nos grupos não tratados é possível visualizar um aumento, porém essas diferenças apresentaram significância estatística somente quando comparados o menor tempo ( 2 dias) com o maior tempo (8 dias) de cultura celular $(p<0,001)$.

Outro fato curioso de se observar é a estrutura do citoesqueleto (actina) das células marcado com faloidina (Texas Red), que parece ser diferente nas células positivas e negativas para Alexa488. Estas diferenças se encontram muito visíveis quando comparamos as Figuras 17.G-1 e 17.H1 e também pode ser bem visualizada na Figura 20, onde é possível se observar que as células positivas para Alexa488 apresentam um citoplasma menor com uma aparente distribuição cortical de actina enquanto aquelas células mais diferenciadas, negativas para Alexa488, apresentam um citoplasma maior e com a formação de stress fibers de actina. A visualização dessas stress fibers de actina em células negativas para a marcação com Alexa488 ocorre tanto em culturas tratadas com atRA (Fig. 17.A-1, A-2, G-1, G-2, I-1, I-2, K1 e K-2), como também em culturas não tratadas (Fig 17. J-1, J-2, L-1 e L-2, e Fig. 20). 


\section{RESULTADOS}

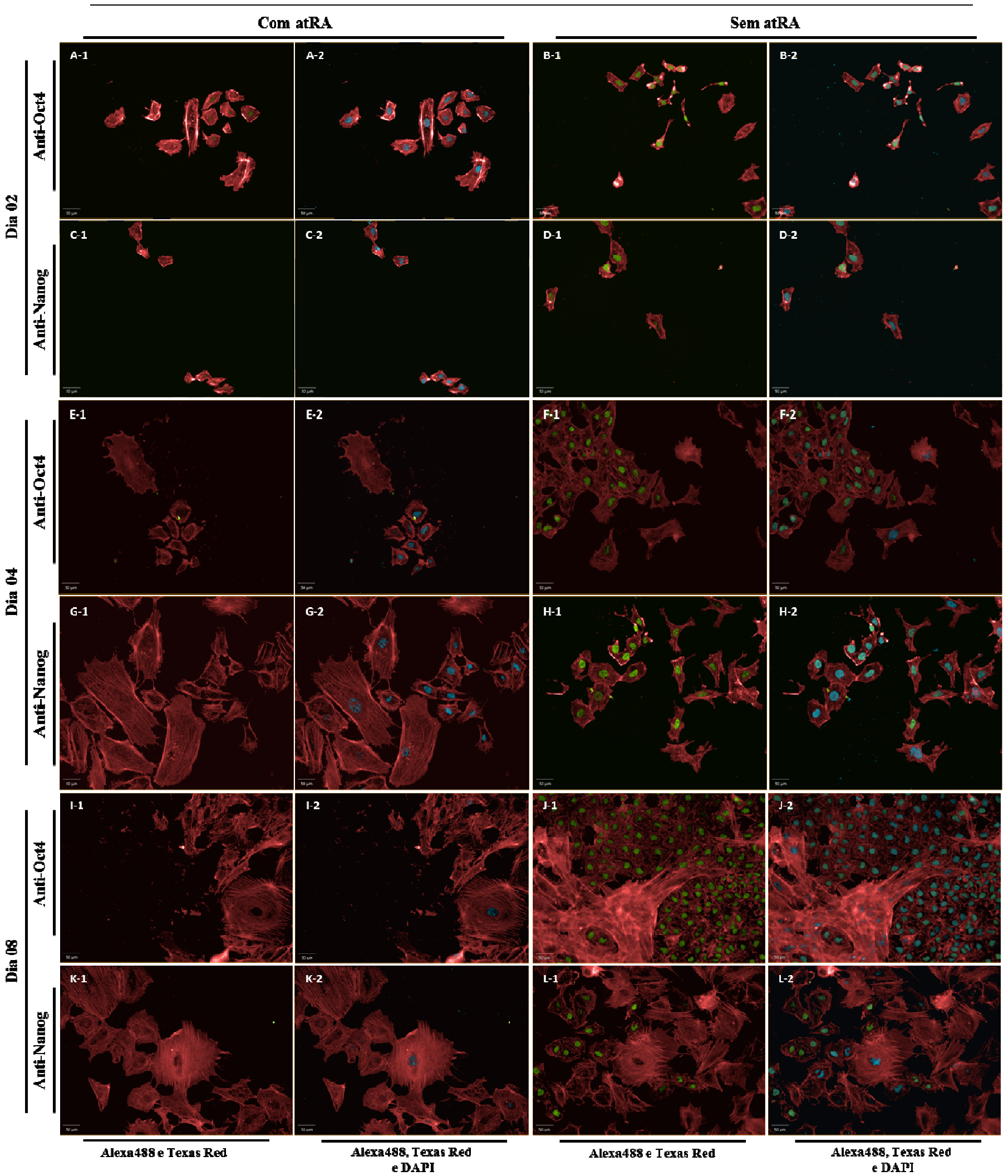

Figura 17 Fotomicrografias obtidas de culturas de células tratadas ou não com ácido trans-retinóico (atRA), marcadas com anticorpos anti-Oct4 ou anti-Nanog (Alexa488, verde), faloidina (Texas Red, vermelho) e DAPI (azul). Nesta figura é possível observar a presença ou ausência da expressão destes fatores de transcrição, observando-se a marcação de Alexa488, que se co-localiza com a marcação nuclear. Também é possível observar a variação da estrutura de actina pela marcação com faloidina. (Aumento: Objetiva 20X) 

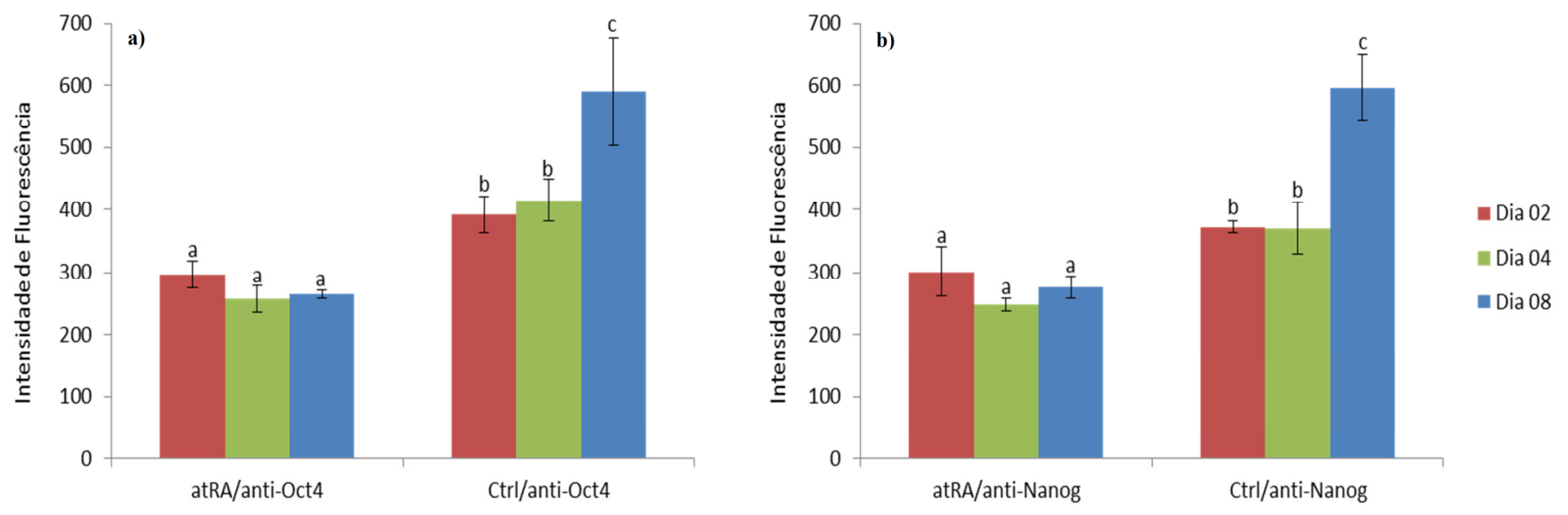

Figura 18 Representação em gráficos dos valores médios de intensidade de fluorescência de Alexa488 na região nuclear das células marcadas com anti-Oct4 (a) ou anti-Nanog (b), tratadas com ácido trans-retinóico (atRA) ou não (Ctrl), mantidas em cultura celular por 2,4 e 8 dias consecutivos. ${ }^{\text {a-c }}$ Letras diferentes representam diferenças estatisticamente significativas $(p<0,01)$.
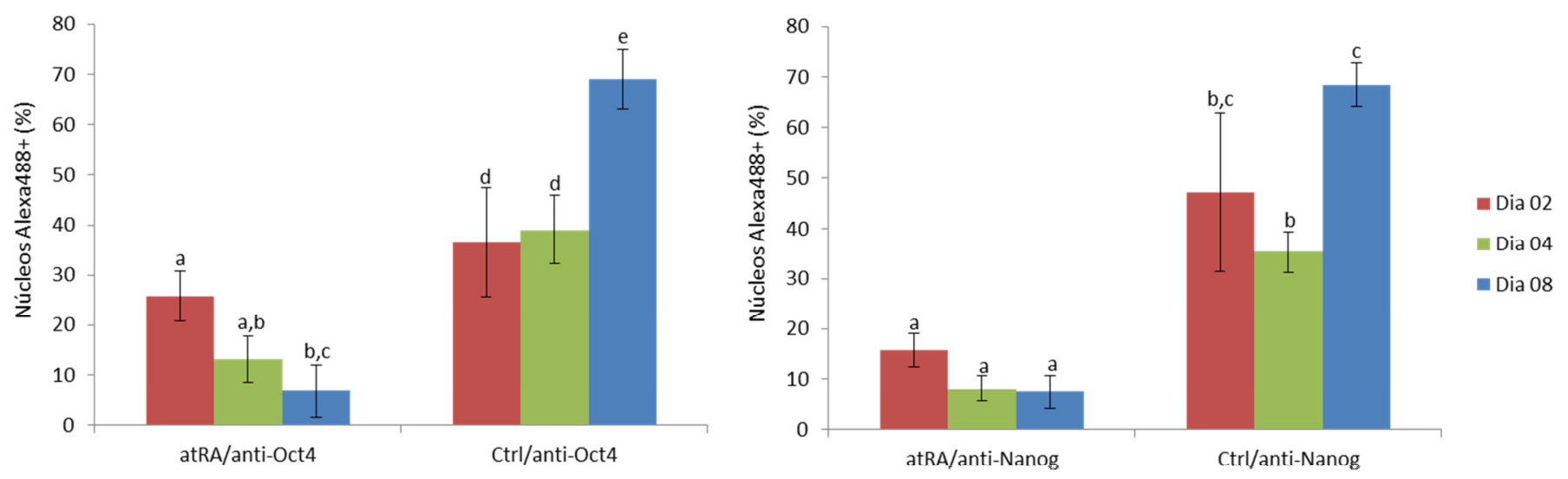

Figura 19 Gráficos apresentando os valores médios da porcentagem de núcleos Alexa488 - de células marcadas com anti-Oct4 (a) ou anti-Nanog (b), tratadas com ácido trans-retinóico (atRA) ou não (Ctrl), mantidas em cultura celular por 2,4 e 8 dias consecutivos. ${ }^{\text {a-e }}$ Letras diferentes representam diferenças estatisticamente significativas $(p<0,01)$. 


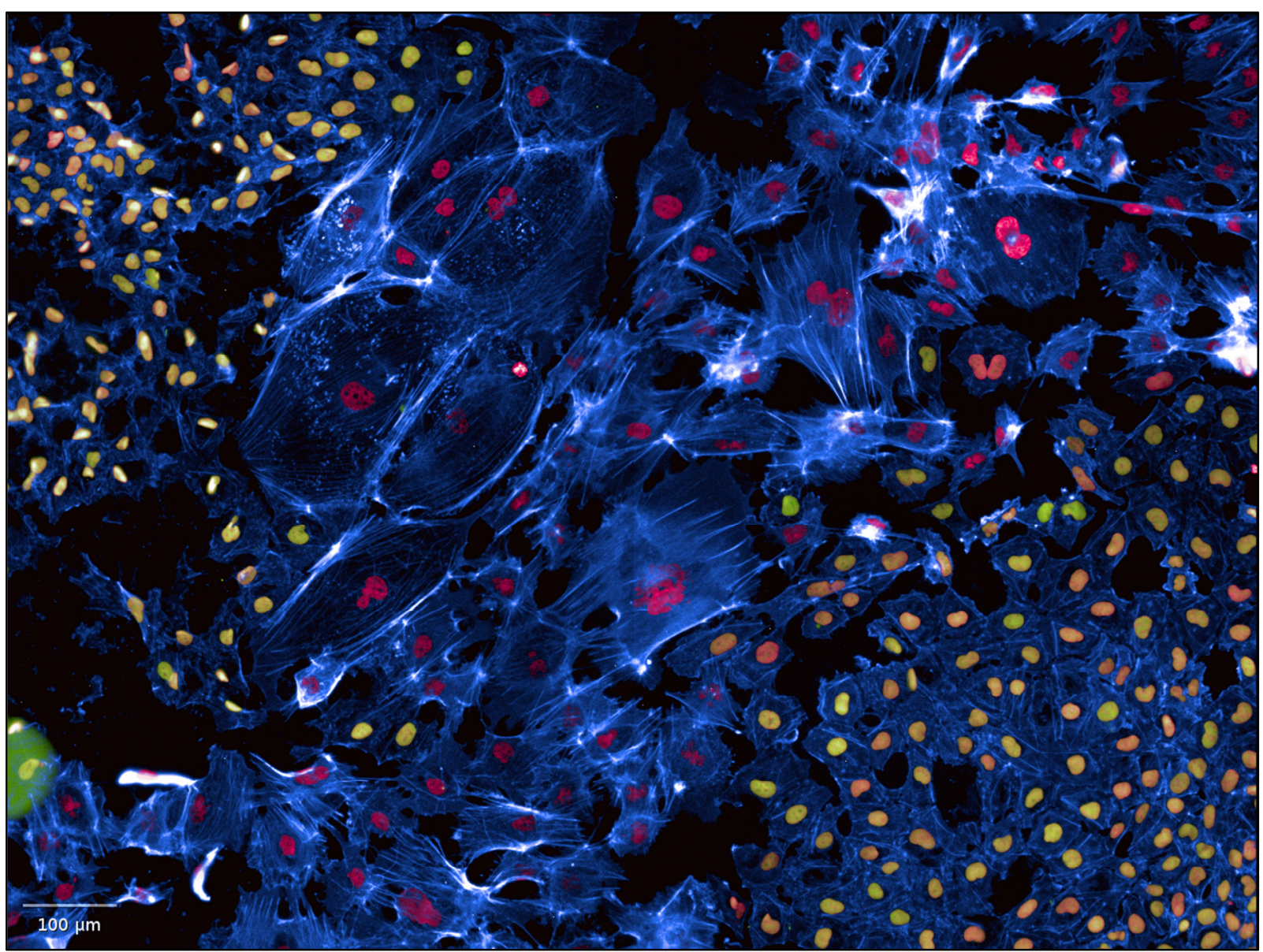

Figura 20 Imagem gerada a partir da fotomicrografia de quatro campos obtidas de culturas de células não submetidas ao tratamento com ácido trans-retinóico após 8 dias em cultura celular. Em azul encontra-se marcada a estrutura do citoesqueleto de actina, em vermelho os núcleos marcados somente com DAPI e em amarelo/alaranjado (variando de acordo com a intensidade de marcação com anti-Oct4) os núcleos com dupla marcação de DAPI e Alexa488. Nesta figura é possível observar células diferenciadas (núcleo vermelho) e células indiferenciadas (núcleo amarelo/alaranjado), como também a estrutura do citoesqueleto de actina, o que nos possibilita a visualização das stress fibers e também de citoplasmas maiores nas células diferenciadas (Aumento: Objetiva 20X)

\subsection{Proliferação Celular}

Para a avaliação do efeito do atRA sobre a proliferação celular da NTera-2, foi realizado o ensaio do XTT e os resultados obtidos por meio deste estão representados nas Figuras 21 e 22. Com este experimento, foi possível observar que as células submetidas ao tratamento com atRA, ou seja, aquelas que foram induzidas à diferenciação celular, apresentaram uma menor taxa de proliferação quando comparadas aos controles de seus respectivos dias. A média de proliferação celular daquelas culturas tratadas por 2 dias com atRA foi de $65,5 \%$; das culturas tratadas por 4 dias a média foi de $73,9 \%$ e daquelas tratadas 
por 8 dias foi de $43,1 \%$. A redução da taxa de proliferação observada em todos os tratamentos foi estatisticamente significativa $(p<0,0001)$ e a menor taxa foi observada naquelas culturas tratadas por um maior período com atRA, o que sugere que com um maior grau de diferenciação a NTera-2 sofre uma diminuição na sua taxa de proliferação.

Na figura 22, onde se encontra representado um gráfico dos valores de absorbância obtidos nos diferentes tempos de cultura das células submetidas ou não à indução de diferenciação celular com atRA, pode-se observar que tanto as células tratadas como as não tratadas continuaram proliferando com o passar do tempo, porém aquelas tratadas com atRA apresentaram um menor índice de proliferação celular se comparadas às não tratadas.

Dia 02

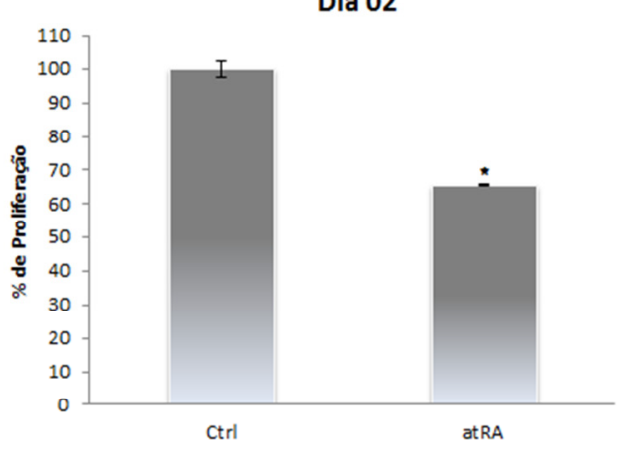

Dia 04

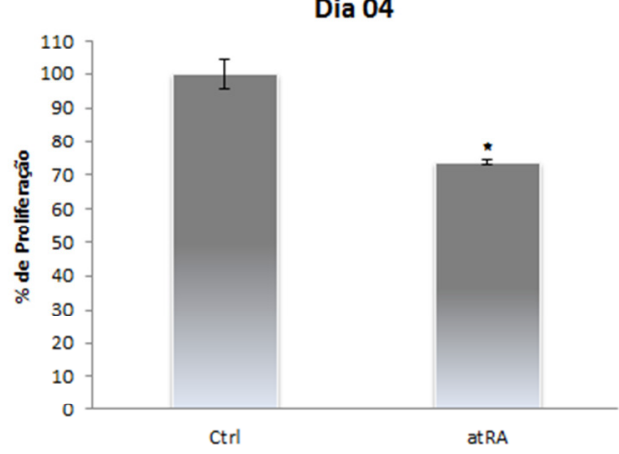

Dia 08

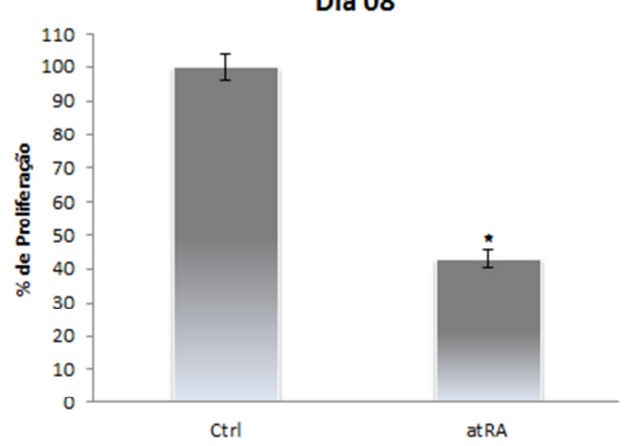

Figura 21 Representação em gráfico dos resultados da análise de proliferação celular obtidos por meio do ensaio do XTT em culturas de NTera-2 tratadas com ácido trans-retinóico (atRA) por diferentes períodos de tempo, sendo estes 2,4 e 8 dias. *diferente do grupo controle $(p<0,001)$

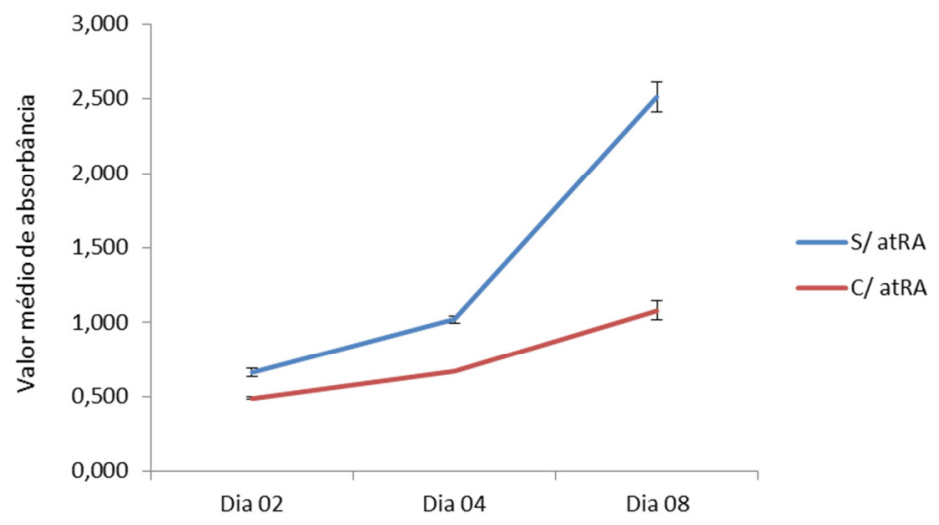

Figura 22 Representação em dos valores médios de absorbância obtidos por meio do ensaio do XTT em culturas de NTera-2 tratadas ou não com ácido trans-retinóico (atRA) pelo período de 2, 4 e 8 dias. 
No presente trabalho foi estudado um método de indução de diferenciação celular em culturas de células NTera-2, visando o estabelecimento de modelos experimentais voltados à futura realização de estudos, visando a avaliação de fatores que possam influenciar a diferenciação celular, positiva ou negativamente. Para isso, tentamos inicialmente, estabelecer linhagens repórteres, com o gene da luciferase sob controle dos fatores de transcrição OCt4 e Nanog. Esta abordagem, no entanto, se mostrou extremamente laboriosa e contra-produtiva. Sem sucesso, decidimos avaliar a possibilidade da realização de ensaios da luciferase baseados na transdução dos vetores com a geração de linhagens repórteres transientes. Por meio desta abordagem, demonstramos com sucesso, a atividade dos dois FT relacionados ao estado pluripotente dessas células, Oct4 e Nanog, na linhagem NTera-2. Posteriormente analisamos a expressão dos transcritos destes FT e também de um indicador de diferenciação celular, a N-Caderina, por meio da técnica de PCR em Tempo Real. A variação da expressão a nível proteico dos FT também foi avaliada por meio da técnica de HCS, utilizando-se o software Harmony 3.0 para a análise das imagens de imunofluorescência obtidas. Também foi avaliado o efeito da indução da diferenciação celular com atRA sobre a proliferação das células NTera-2 por meio do ensaio do XTT.

Muito do que se sabe hoje em dia sobre as CT pluripotentes derivadas da massa interna do blastocisto foi baseado no estudo de CTE não humanas e de células derivadas de carcinoma embrionário (Pal e Ravindran, 2006). O estudo das CCE tem servido como modelo para o entendimento dos mecanismos moleculares envolvidos no comprometimento celular durante o desenvolvimento embrionário, bem como modelos para a padronização de testes de caracterização de CTE humanas (Andrews, 2002; Andrews et al., 1984, 2005; Giesberts et al., 1999).

A linhagem de CCE humano NTera-2 é uma das linhagens mais utilizadas para estudos relacionados à diferenciação celular de $\mathrm{CT}$ pluripotentes, pois estas células mantém alta 
capacidade de diferenciação in vitro (Pal e Ravindran, 2006), possuem uma expressão gênica global altamente similar à CTE indiferenciadas (Schwartz et al., 2005) e são de fácil cultivo, se comparadas com linhagens celulares de CTE ou de outras CCE que necessitam de meios de culturas específicos e/ou de feeder para manterem seu fenótipo pluripotente in vitro (Andrews, 2002; Andrews et al., 1984).

O uso da luciferase como repórter para estudos de expressão gênica, avaliação da atividade de fatores de transcrição específicos ou outros, tem sido amplamente realizado em diferentes áreas da biologia (Aoki et al., 2000; Kuroda et al., 2013; Su et al., 2011; Yao et al., 2010). Neste trabalho foi realizada a tentativa de se gerar linhagens repórteres estáveis utilizando-se de lentivírus, com o intuito de se estudar a atividade de FT relacionados à manutenção do estado pluripotente da linhagem de carcinoma embrionário NTera-2 frente ao tratamento com diferentes agentes que poderiam induzir ou reprimir a diferenciação celular. Porém, como observado nos resultados, mesmo em células que se tornavam resistentes ao antibiótico de seleção, não foi possível se obter uma linhagem que mantivesse a expressão do gene repórter.

Os pesquisadores Stewart e colaboradores (2008) realizaram experimentos com o objetivo de gerar linhagens de CTE e CCE humanas contendo um gene repórter para a atividade de três diferentes fatores relacionados às suas características pluripotentes, $h$ Tert, Terf1 e Oct4. No trabalho publicado por este grupo foi notado que, durante o tempo em cultura celular, as linhagens repórteres ditas como estáveis perdiam o sinal do repórter. Eles também observaram que o nível de expressão do gene de resistência ao antibiótico de seleção decaiu com o passar do tempo, porém as células mantinham-se resistentes ao antibiótico do mesmo modo. Depois de algumas análises, o grupo chegou a conclusão de que eventos epigenéticos tais quais metilação do DNA ou modificações de histonas poderiam estar envolvidos o silenciamento dos transcritos. Mantendo em linha o mesmo pensamento, pode-se 
dizer então que, no presente trabalho, o não sucesso na geração de linhagens repórteres estáveis para a atividade de Oct4 e Nanog pode estar relacionado a mecanismos epigenéticos de silenciamento presentes em células pluripotentes.

Uma alternativa para a realização da avaliação da atividade dos FT em questão seria a realização de um ensaio transiente, onde as células seriam transduzidas e submetidas às análises em um período de tempo curto (Stewart et al., 2008). Portanto, foi realizado o teste transiente para a verificação da atividade de Oct4 e Nanog na linhagem celular NTera-2 por meio do ensaio da luciferase e observou-se que os mesmos se encontravam ativos, pois a bioluminescência observada nesta linhagem se mostrou mais intensa do que em uma célula sabidamente diferenciada e sem expressão destes FT, o fibroblasto BJ. Apesar do sucesso, tendo em vista o alto custo envolvido na obtenção das partículas virais, bem como as dificuldades técnicas relacionadas à sua manipulação, a realização de ensaios transientes torna-se desvantajosa. Por este motivo, o ensaio da luciferase foi utilizado somente para a constatação da atividade dos fatores mantenedores do estado pluripotente presente na linhagem celular NTera-2.

Para estudos do comportamento celular e elucidação de mecanismos envolvidos com o potencial de auto-renovação e de diferenciação celular de células pluripotentes, o uso de CCE é comum, pois estas células, como dito anteriormente, apresentam vantagens em relação às CTE se compararmos a facilidade e o custo para a manutenção das CCE em culturas celulares (Andrews et al., 1984, 2005; Schwartz et al., 2005). Diversos estudos de diferenciação celular utilizando linhagens de CCE já foram realizados e a partir destas linhagens foi possível a obtenção de células com características dos três folhetos embrionários (Pal e Ravindran, 2006). Particularmente quando se estuda a linhagem de CCE NTera-2, a mesma utilizada no presente estudo, é notável a capacidade que esta linhagem celular possui de diferenciar-se em células do tecido nervoso (incluindo células da glia e de neurônios), principalmente naqueles 
estudos em que o ácido retinóico foi utilizado como indutor de diferenciação celular (Andrews, 1984; Jones-Villeneuve et al., 1982; Sandhu, Sikorska e Walker, 2002; Tan e Bicker, 2003; Zeller e Strauss, 1995).

Os retinóides têm um papel essencial em uma grande variedade de importantes processos biológicos, tais como o crescimento, visão, diferenciação e desenvolvimento embrionário (Tzimas e Nau, 2001). No organismo adulto, eles são adquiridos por meio da ingestão de alimentos contendo ésteres de retinil ou carotenóides, os quais são enzimaticamente convertidos em retinol, e então lançados na corrente sanguínea, ligando-se e sendo transportado pela proteína ligadora de retinol. Nas células, o retinol é convertido em retinal e ácido retinóico (Blomhoff e Blomhoff, 2006). O ácido retinóico age como um ligante para o receptor de ácido retinóico (RAR) e, quando ativado, este RAR se liga a regiões promotoras de diferentes genes, sendo sugeridos mais de 500 genes alvos controlados pelo RAR, podendo esta regulação ocorrer de forma direta ou indireta (Bastien e Rochette-Egly, 2004; Fields, Soprano e Soprano, 2007). Dentre estes genes encontram-se genes envolvidos com a diferenciação celular e morfogênese, como Oct4, Hox e TGF $\beta$ (Eifert et al., 2006; Love e Gudas, 1994). A ação repressora do ácido retinóico sobre os níveis de expressão de Oct4 foi observada por meio de experimentos com linhagens de CCE (Pacherník et al., 2005; Schoorlemmer et al., 1995) e CTE (Faherty, Kane e Quinlan, 2005).

Ao analisarmos os dados de expressão gênica obtidos por meio do estudo dos transcritos de Oct4, Nanog e N-Caderina, utilizando-se das técnicas de PCR em tempo real, foi possível observar que a indução da diferenciação celular com atRA mostrou uma alta eficiência, já que os níveis de expressão de Oct4 e Nanog começou a decair logo após dois dias de tratamento, chegando a níveis praticamente nulos a partir do quarto dia de tratamento. Também foi possível observar que os níveis de expressão de N-Caderina começaram a elevar- 
se logo no período inicial de tratamento e continuou se elevando conforme o tempo em cultura, com o tratamento.

Nas culturas de células não submetidas ao tratamento com atRA também foi possível observar a queda da expressão de Oct4 e Nanog, quando estas foram mantidas por maior tempo em cultura celular, porém não foi observado o aumento da expressão de N-Caderina. Sabe-se que culturas de células pluripotentes mantidas em alta confluência por um longo período de tempo sofrem diferenciação espontânea (Andrews, 2002), e isso foi observado por nós, por meio da perda de expressão dos fatores de pluripotência e pelas alterações morfológicas.

De forma condizente com os resultados de expressão gênica a nível transcricional, os resultados obtidos nas análises de HCS, quanto à expressão de Oct4 e Nanog nas células em cultura, demonstraram que, conforme o tempo de tratamento com atRA os níveis de expressão dessas proteínas decaiu. A observação deste resultado pode ser feita tanto na análise visual qualitativa das imagens obtidas por imunofluorescência, como na análise quantitativa dos dados obtidos por meio da mensuração da intensidade de fluorescência do marcador dos FT em questão (Alexa488) na região nuclear, como também; pela porcentagem de núcleos positivos para esta marcação em relação ao número total de núcleos (marcados com DAPI).

A perda da expressão de Oct4 e Nanog nas culturas não submetidas ao tratamento com atRA analisadas por PCR em tempo real, mantidas por maior tempo em cultura, não foi observada nas análises de HCS. Essa não concordância entre os dados de análises da expressão de transcritos e de expressão protéica pode ter ocorrido devido ao fato de que, para os experimentos de PCR em tempo real, as células foram plaqueadas em maior densidade (3 vezes mais) em relação à área da placa de cultura utilizada (6 poços, área: $962 \mathrm{~mm}^{2}$ ) se compararmos com a densidade celular plaqueada para o ensaio de HCS (96 poços; área: $32 \mathrm{~mm}^{2}$ ). Essa maior confluência celular nos grupos analisados por PCR em tempo real pode 
ter levado à indução da diferenciação, enquanto nas culturas utilizadas para HCS existia um espaço maior, permitindo que as células continuassem proliferando e não sofrendo diferenciação.

Durante a diferenciação, a perda da expressão dos fatores de pluripotência Oct4 e Nanog pode ocorrer por meio de diversos mecanismos. Dentre estes mecanismos, podemos citar a metilação de DNA, um exemplo clássico de controle epigenético sobre a expressão gênica durante o desenvolvimento e que também exerce papéis importantes para a manutenção das funções das CT (Tollervey e Lunyak, 2012). O trabalho de Deb-Rinker e colaboradores (2005) relatou a metilação sequencial de Nanog e Oct4 em ilhas CpG upstream durante a indução de diferenciação de células pluripotentes por meio do uso do ácido retinóico, utilizando como modelo a NTera-2. Junto à análise de metilação, este grupo também realizou uma análise de expressão gênica destes fatores e foi observado que os níveis de expressão de Nanog e Oct4 decaiam logo nos dois primeiros dias de tratamento com o ácido retinóico, sendo que os níveis de expressão de Nanog decaem mais rapidamente que os de Oct4, e esses níveis continuaram decaindo conforme o maior tempo de cultura celular com ácido retinóico. Após o período de quatro dias de tratamento com ácido retinóico os níveis de expressão destes FT já se encontravam praticamente nulos. Os dados de expressão gênicas obtidos por este grupo corroboram com os dados obtidos no presente trabalho.

No que se diz respeito ao perfil de metilação das ilhas $\mathrm{CpG}$ nas regiões promotoras destes genes, níveis mais elevados de metilação só foram observados a partir do quarto dia de cultura destas células induzidas à diferenciação e com o passar do tempo em cultura celular, o grau de metilação nessas regiões se elevou gradativamente. É sabido que a metilação de DNA em genes essenciais para a manutenção do fenótipo de CT ocorre inicialmente na região codante e não na promotora (Lister et al., 2009; Tollervey e Lunyak, 2012) e isso explicaria a diminuição nos níveis de expressão de Oct4 e Nanog nos dias iniciais de tratamento com 
atRA sem a notificação de um aumento expressivo de metilação nas regiões promotoras destes genes.

Outro mecanismo epigenético de regulação da expressão gênica que tem se apresentado como um importante regulador de diversos processos biológicos é a rede de miRNAs (Ambros, 2004; Tollervey e Lunyak, 2012; Zhao e Srivastava, 2007). Com base na literatura, é sabido que determinados miRNAs apresentam-se mais expressos em células indiferenciadas e, conforme essas células começam a diferenciar-se, o nível de expressão destes decai. O oposto também ocorre com diferentes miRNAs, sendo que estes não se apresentam expressos ou apresentam baixos níveis de expressão nas células indiferenciadas e sofrem um aumento de expressão conforme as células se diferenciam (Stadler et al., 2010; Xu et al., 2009).

No trabalho de Stadler e colaboradores (2010), os miRNAs que mostraram maiores níveis de expressão durante a diferenciação inicial de CT pluripotentes foram: miR-145, o cluster miR-24/miR-27a/miR-23a, miR-21 e miR-29a. Os pesquisadores Xu e colaboradores (2009), ao notarem a alta expressão do miR-145 em células pluripotentes submetidas à indução de diferenciação celular, realizaram diferentes experimentos para determinar quais eram os possíveis alvos deste miRNA e como resultados encontraram que este miRNA tem como alvos três diferentes FT de células pluripotentes e dentre eles encontra-se o Oct4, e que este miRNA sozinho é capaz de induzir a diferenciação celular de CTE. Com o silenciamento do Oct4 e dos outros FT, ocorre também o silenciamento do Nanog, já que, juntos ao Sox2, Oct4 e Nanog formam uma rede autorregulada que mantém o fenótipo pluripotente das CTE e CCE (Boyer et al., 2005; Loh et al., 2006).

Outros miRNAs podem agir de uma forma mais indireta, induzindo a diferenciação celular e perda da expressão dos fatores de pluripotência por meio da ativação de diferentes vias, não se ligando diretamente a transcritos de FT como Oct4, Nanog, Sox2 e Klf4. Neste caso, podemos tomar como exemplo o miR-29a, que inibe a síntese de CDC42 e de p85a, 
induzindo indiretamente o aumento dos níveis de p53 (Park et al., 2009), que por sua vez é capaz de induzir diferenciação celular, como constatado por Jain e colaboradores (2012) por meio da indução da expressão de p53 em culturas de CTE humanas, resultando na perda de marcadores de pluripotência como fosfatase alcalina, SSEA-4 e Oct4, e induzindo modificações morfológicas nessas células.

No que se diz respeito à expressão de N-Caderina, é sabido que a linhagem de carcinoma embrionário NTera-2 não expressa esta proteína (Bremmer et al., 2012) quando em seu estado indiferenciado. Ao submetermos estas células ao tratamento com atRA induzimos assim a sua diferenciação celular e sabe-se que o uso deste indutor nessa linhagem de CCE faz com que esta tenha um comprometimento com tipos celulares originados da ectoderme (Andrews, 1984; Jones-Villeneuve et al., 1982; Shahhoseini et al., 2010; Zeller e Strauss, 1995).

As caderinas são glicoproteínas transmembrana, dependentes de $\mathrm{Ca}^{2+}$, e atuam como moléculas de adesão celular. Estas proteínas são conhecidas por seu importante papel no contato célula-célula, no desenvolvimento de diferentes órgãos e até na tumorigênese (Angst, Marcozzi e Magee, 2001; Potter, 1999; Takeichi, 1995). A N-Caderina é uma caderina neural, que foi inicialmente detectada no tecido cerebral de camundongos, mas que desempenha um papel importante na migração e diferenciação celular, no desenvolvimento embrionário e no comportamento metastático de células tumorais (Gumbiner, 2005; Sayegh, El, Kapus e McCulloch, 2007). Visto que o tratamento com atRA induz a diferenciação da NTera-2 para ectoderme, é compreensível que os níveis de expressão desta proteína se eleve com o tempo de cultura celular com o tratamento e este aumento progressivo se deve também à diferenciação progressiva das células, que para gerarem neurônios necessitam de um longo tempo em cultura celular (Andrews, 1984; Zeller e Strauss, 1995). 
Mesmo as células não tratadas com atRA, apresentaram perda da expressão de Oct4 e Nanog, com o tempo em cultura. Por outro lado, o aumento dos níveis transcricionais de NCaderina pode não ter sido observado devido à diferenciação celular da linhagem NTera-2 para algum tipo celular não-neuronal, já que esta célula pode diferenciar-se em células derivadas dos três diferentes folhetos embrionários. No trabalho de Simões e Ramos (2007) foi observado que a manutenção de culturas de NTera-2 por longos períodos, sem repiques, levaram ao aparecimento de estruturas parecidas com corpos embrióides, circulados por uma camada epitelióide escamosa de células achatadas, semelhantes a um fenótipo de endoderme visceral. Um padrão similar a este foi observado no presente estudo nas culturas celulares mantidas por longo período de tempo.

Durante a indução da diferenciação celular das culturas de NTera-2, foi observado, por meio do ensaio do XTT, que as células tratadas com atRA apresentavam um menor potencial de proliferação celular do que aquelas não submetidas ao mesmo tratamento. A visualização disto foi possível tanto ao compararmos os grupos de células tratadas com os controles cultivados pelo mesmo período de tempo, como também, observando-se temporalmente o aumento do número de células (como determinado pelo aumento dos valores de absorbância).

Sabe-se que o potencial de auto-renovação e manutenção do fenótipo de CT pluripotente está ligado à habilidade que essas células possuem de manter-se em um processo de proliferação celular contínuo e abreviado (Jirmanova et al., 2002; Stead et al., 2002), caracterizado por uma fase G1 curta, com elevada expressão de ciclinas associadas à G1, ciclinas dependentes de kinases ativas e baixos níveis de inibidores de ciclo celular (Becker et al., 2006). Em linha, durante o processo de indução de diferenciação celular em CTE por meio do uso de ácido retinóico, o número de células encontrados na fase G1 aumenta, se comparado às células não diferenciadas, que se apresentavam na fase $S$, em sua grande maioria (Jain et al., 2012). 
Mais uma vez, diversos fatores podem se encontrar por detrás deste processo de parada ou diminuição do ciclo celular. Podemos citar a ativação de p53 por meio do tratamento com atRA, que leva à elongação da fase G1 por meio da indução de uma proteína inibidora do ciclo celular, a p21, e também induz o aumento dos níveis de expressão de miRNAs que possuem como alvos os FT relacionados à manutenção do estado pluripotente dessas CT, os miR-34 e miR-145 (Jain et al., 2012). A perda da expressão dos FT de células pluripotentes também leva à perda ou diminuição da expressão de miRNAs responsáveis por manter o ciclo celular destas células em velocidade elevada. Exemplos de miRNAs que atuam desta maneira são miR-195, miR-372 e miR-290-295, que possuem como alvos proteínas que regulam negativamente o ciclo celular (Tiscornia, Izpisúa Belmonte e Izpisu, 2010).

Nas imagens de imunofluorescência obtidas para a realização das análises de HCS, foi possível observar uma variação na estrutura do citoesqueleto de actina, que se encontrava marcada com faloidina conjugada a um fluoróforo (Texas Red). Como dito na descrição dos resultados, as células que apresentavam marcação positiva para Oct4 e Nanog exibiam um posicionamento mais cortical da actina, enquanto aquelas células que não apresentavam tal marcação, em sua maioria, apresentava stress fibers de actina e um citoplasma maior.

A actina é uma proteína do citoesqueleto que desempenha um papel importante em diferentes processos celulares, tais como migração, morfogênese, citocinese e fagocitose, e por esta razão a regulação precisa da estrutura e da dinâmica do citoesqueleto de actina é essencial para o funcionamento correto de diferentes processos (Pollard e Cooper, 2009). As stress fibers de actina são estruturas contráteis encontradas em diversos tipos celulares como fibroblastos, miócitos de músculo liso e células endoteliais (Pellegrin e Mellor, 2007). Esse tipo de estrutura é bem visualizado em células com fenótipo mesenquimal, pois são responsáveis pela capacidade de migração destas células por entre a matriz extracelular 
(Baum, Settleman e Quinlan, 2008; Murray e Saint, 2007; Tojkander, Gateva e Lappalainen, 2012).

As CT pluripotentes apresentam um fenótipo epitelial (Liao et al., 2011), portanto o aparecimento das stress fibers de actina sugere que as células em processo de diferenciação estão passando por uma transição epitélio-mesênquimal (EMT), um processo biológico central de diferenciação na fase inicial da morfogênese embrionária, onde células de fenótipo epitelial sofrem mudanças no seu perfil molecular e celular, definidos por redução da adesão célula-célula, polaridade apical-basolateral e de marcadores epiteliais e ganho de marcadores mesenquimais, motilidade e de um formato celular fusiforme, transitando para um fenótipo mesenquimal (Cowin e Welch, 2007; Shook e Keller, 2003). Como um exemplo de molécula regulada positivamente durante a EMT, podemos tomar a N-Caderina e isto pode se dar pela razão das interfaces célula-célula mediadas por esta molécula serem menos estáveis (Derycke e Bracke, 2004; Nakagawa e Takeichi, 1995; Takeichi, 1988). Porém existem tipos celulares que, ao sofrerem o processo de EMT, não apresentam um aumento na expressão de $\mathrm{N}$ Caderina e também existem casos em que esta molécula faz parte da construção de um epitélio (Ahlstrom e Erickson, 2009; Baum, Settleman e Quinlan, 2008; Hayashi e Carthew, 2004).

Esse tipo de transição permitiu a geração morfogênica de estruturas embrionárias complexas, pois as células com fenótipo mesenquimal podem migrar individualmente, de forma tridimensional e este tipo de migração pode estar envolvido, por exemplo, com a migração inicial dos gametas ou de células em divisão (Pérez-Pomares e Muñoz-Chápuli, 2002; Shook e Keller, 2003). Após chegarem ao seu destino final, essas células mesenquimais podem diferenciar-se e até retomar a um fenótipo epitelial (Hay, 1995).

Atualmente, o estudo do papel dos miRNAs nos processos de EMT e MET (Bullock et $a l .$, 2012) e no controle da pluripotência, auto-renovação e reprogramação, vem recebendo 
cada vez mais destaque na literatura especializada (Chang and Gregory, 2011; Kuo and Ying, 2012; Kuo et al., 2012; Pfaff et al., 2011, 2012).

Os estudos acima revelaram o efeito de alguns miRNAs sobre determinados processos biológicos e os potenciais mecanismos moleculares intermediando estes efeitos. Apesar destes estudos indicarem a importância de vários miRNAs na manutenção e na indução da pluripotência, os miRs avaliados até o momento são apenas uma pequena parcela dos miRs diferencialmente expressos entre as células-tronco pluripotentes e as células diferenciadas (Lakshmipathy, et al 2007, Ren, et al 2009, Stadler, et al 2010, Suh, et al 2004, Wilson, et al 2009). É importante ressaltar que, no presente estudo, a análise simultânea da expressão de marcadores de células pluripotentes e da conformação do citoesqueleto de actina permitiu a avaliação do processo de diferenciação por uma visão mais ampla, tornando possível a observação das alterações morfológicas da célula acompanhada da presença ou ausência da expressão de FT relacionados ao fenótipo pluripotente.

Conhecendo-se moléculas que podem agir sobre os processos de EMT e MET torna-se possível uma aplicação destas para fins tais como controle da diferenciação celular e indução de pluripotência, já que o processo de MET, por exemplo, é um processo chave para a geração de iPSC (Li et al., 2010).

Com isto em vista, a utilização deste modelo desenvolvido no presente trabalho permitiria a avaliação de moléculas (como os miRNAs) que podem atuar regulando vias que afetam a manutenção do estado pluripotente e, ao mesmo tempo, vias de controle da EMT e/ou MET (transição mesenquimal-epitelial). 
Apesar de termos tido sucesso nos ensaios de luciferase utilizando a transdução de vetores repórteres lentivirais de modo transiente, as dificuldades técnicas e o alto custo que decorreria desta abordagem, limita sua aplicação em screenings de larga-escala. Por outro lado, o estabelecimento de uma linhagem repórter estável, permitiria a realização de screenings com características desejáveis, incluindo baixo custo, facilidade técnica, rapidez e fácil interpretação. Esta foi a razão de termos tentado, inicialmente, obtermos linhagens repórteres estáveis, porem sem sucesso. Por outro lado, mesmo que tivéssemos logrado êxito, o uso de ensaios baseados em testes bioquímicos (como o da luciferase), apresenta várias limitações quanto à quantidade de informação potencialmente obtida com este tipo de ensaio. De fato, as informações derivadas dos ensaios com os repórteres de luciferase poderiam fornecer apenas, a informação sobre o estado de ativação transcricional do fator em questão (Oct4 ou Nanog), em um nível populacional (uma vez que a atividade da luciferase é quantificada no conjunto total de células, após sua lise).

Em contraste aos métodos bioquímicos de HTS, as abordagens de HCS se baseiam na quantificação de múltiplas características fenotípicas, de forma simultânea, pela aquisição e análise automatizada de imagens de imunofluorescencia. Este tipo de abordagem permite que as características das diferentes células em uma população sejam interrogadas independentemente. Neste sentido, a utilização simultânea de anticorpos contra um marcador de pluripotência (Oct4 ou Nanog), em associação ao uso da faloidina para marcação da alfaactina e, ainda, o uso do corante de ácidos nucleicos DAPI como marcador nuclear, permitiu a observação simultânea da expressão e localização intra-celular dos fatores de transcrição Oct4 e Nanog, em relação às mudanças na organização da actina e na morfologia celular, associadas ao importante processo de Transição Epitelio-Mesenquimal (EMT).

A avaliação de marcadores de pluripotência e de EMT, na linhagem celular NTera-2 (na presença ou ausência do indutor atRA), demonstrou que o tempo de cultura influencia o 
processo de diferenciação. Mais especificamente, enquanto os níveis transcricionais de Oct4 ou Nanog são reduzidos ao longo do período avaliado, mesmo na ausência de atRA; o aumento a expressão de N-Caderina só ocorre na presença do indutor. O resultado observado por imunofluorescência, por sua vez, confirma uma redução tempo-dependente da porcentagem de células positivas para os marcadores Oct4 e Nanog. Em conjunto, estes resultados indicam que, para que um ensaio com base nestes marcadores seja capaz de discernir entre condições experimentais que promovam ou reprimam os processos de diferenciação ou EMT, uma importância especial deve ser dada para o exato momento em que será realizada a avaliação. A titulo de ilustração, caso um screening fosse realizado após 8 dias de cultivo na presença de atRA (quando somente cerca de 5\% das células expressam Oct4 ou Nanog), somente fatores reprimindo o processo de diferenciação (ou seja, que impedissem a perda de expressão destes marcadores) seriam preferencialmente identificados (por ex., microRNAs envolvidos na manutenção da pluripotência). Concluísse, portanto, que para a realização de um screening mais abrangente, idealmente cerca de $50 \%$ das células deveriam expressar estes marcadores.

Importantemente, as variações qualitativas observadas (referentes à expressão dos marcadores de pluripotência) puderam ser traduzidas numericamente (mesmo que por abordagens de quantificação ainda preliminares), demonstrando que ensaios similares ao estabelecido neste trabalho, poderão ser utilizados para a realização de ensaios futuros de HCS. Por outro lado, a falta de um marcador de membrana citoplasmática (ou mesmo de citoplasma), impediu que outras quantificações fossem obtidas. Mais especificamente, a faloidina por si só, não permitiu a delimitação das células; impedindo assim, a determinação do tamanho celular, assim como a definição de um método para definir e quantificar o fenótipo epitelial (uu mesenquimal). A adição de um marcador para esta finalidade permitirá a 
aquisição simultânea de ainda mais informações, em um mesmo ensaio; de forma a maximizar as informações provenientes de um mesmo screening. 
7. Perspectivas Futuras 
Com a caracterização e padronização do presente modelo para estudos de modulação da pluripotência e diferenciação celular, será possível a realização de projetos voltados para estudos em larga escala de moléculas que possam atuar no processo de diferenciação celular. Um destes projetos, que já se encontra elaborado, tem como objetivo a avaliação do papel dos miRNAs na proliferação e diferenciação celular da linhagem pluripotente, utilizando uma biblioteca de miRNAs que contém moléculas que correspondem a mais de 1000 miRNAs presentes na versão 16.0 da miRBase (www.mirbase.org). Serão utilizadas tanto moléculas precursoras de miRNAs (pré-miRs) quanto moléculas inibidoras de miRNAs endógenos (antimiRs), para avaliar assim, respectivamente, o efeito do ganho ou perda da função de um determinado miRNA sobre os processos que serão estudados. A partir destes dados gerados, outros ensaios mais pontuais serão realizados para uma melhor caracterização da função dos miRNAs selecionados e um entendimento melhor dos mecanismos de ação destes sobre os processos biológicos de diferenciação e proliferação celular. 
AHLSTROM, J. D.; ERICKSON, C. A. The neural crest epithelial-mesenchymal transition in 4D: a "tail" of multiple non-obligatory cellular mechanisms. Development (Cambridge, England), v. 136, n. 11, p. 1801-12, jun. 2009.

AMBROS, V. The functions of animal microRNAs. Nature, v. 431, n. 7006, p. 350-5, 16 set. 2004.

ANDREWS, P. W. et al. Cell-surface antigens of a clonal human embryonal carcinoma cell line: morphological and antigenic differentiation in culture.International journal of cancer. Journal international du cancer, 15 maio. 1982. Disponível em: $<$ http://www.ncbi.nlm.nih.gov/pubmed/7095898>

ANDREWS, P. W. et al. Three monoclonal antibodies defining distinct differentiation antigens associated with different high molecular weight polypeptides on the surface of human embryonal carcinoma cells.Hybridoma, jan. 1984. Disponível em: <http://www.ncbi.nlm.nih.gov/pubmed/6396197>

ANDREWS, P. W. et al. Two monoclonal antibodies recognizing determinants on human embryonal carcinoma cells react specifically with the liver isozyme of human alkaline phosphatase.Hybridoma, jan. 1984.2 Disponível em: <http://www.ncbi.nlm.nih.gov/pubmed/6205984>

ANDREWS, P. W. et al. Pluripotent embryonal carcinoma clones derived from the human teratocarcinoma cell line Tera-2. Differentiation in vivo and in vitro. Laboratory investigation; a journal of technical methods and pathology, v. 50, n. 2, p. 147-62, fev. 1984.

ANDREWS, P. W. Retinoic acid induces neuronal differentiation of a cloned human embryonal carcinoma cell line in vitro. Developmental biology, v. 103, n. 2, p. 285-93, jun. 1984.

ANDREWS, P. W. et al. Different patterns of glycolipid antigens are expressed following differentiation of TERA-2 human embryonal carcinoma cells induced by retinoic acid, hexamethylene bisacetamide (HMBA) or bromodeoxyuridine (BUdR). Differentiation; research in biological diversity, v. 43, n. 2, p. 131-8, abr. 1990.

ANDREWS, P. W. et al. Inhibition of proliferation and induction of differentiation of pluripotent human embryonal carcinoma cells by osteogenic protein-1 (or bone morphogenetic protein-7). Laboratory investigation; a journal of technical methods and pathology, v. 71, n. 2, p. 243-51, ago. 1994.

ANDREWS, P. W. From teratocarcinomas to embryonic stem cells. Philosophical transactions of the Royal Society of London. Series B, Biological sciences, v. 357, n. 1420, p. 405-17, 29 abr. 2002.

ANDREWS, P. W. et al. Embryonic stem (ES) cells and embryonal carcinoma (EC) cells: opposite sides of the same coin. Biochemical Society transactions, v. 33, n. Pt 6, p. 1526-30, dez. 2005. 
ANGST, B. D.; MARCOZZI, C.; MAGEE, A I. The cadherin superfamily: diversity in form and function. Journal of cell science, v. 114, n. Pt 4, p. 629-41, fev. 2001.

AOKI, Y. et al. Selective stimulation of G-CSF gene expression in macrophages by a stimulatory monoclonal antibody as detected by a luciferase reporter gene assay Abstract : We have identified a stimulatory mono- clonal antibody $(\mathrm{mAb})$ from autoimmune mice that the sple. v. 68, n. November, p. 757-764, 2000.

BADCOCK, G. et al. The human embryonal carcinoma marker antigen TRA-1-60 is a sialylated keratan sulfate proteoglycan. Cancer research, v. 59, n. 18, p. 4715-9, 15 set. 1999.

BARBARIC, I.; HARRISON, N. J. Rediscovering pluripotency: from teratocarcinomas to embryonic stem cells. Cardiff, 10-12 October 2011. The International journal of developmental biology, v. 56, n. 4, p. 197-206, jan. 2012.

BARTEL, D. P. Review MicroRNAs : Target Recognition and Regulatory Functions. p. 215233, 2009.

BARTEL, D. P.; LEE, R.; FEINBAUM, R. MicroRNAs : Genomics , Biogenesis , Mechanism, and Function Genomics : The miRNA Genes. v. 116, p. 281-297, 2004.

BASTIEN, J.; ROCHETTE-EGLY, C. Nuclear retinoid receptors and the transcription of retinoid-target genes. Gene, v. 328, p. 1-16, 17 mar. 2004.

BAUM, B.; SETTLEMAN, J.; QUINLAN, M. P. Transitions between epithelial and mesenchymal states in development and disease. Seminars in cell \& developmental biology, v. 19, n. 3, p. 294-308, jun. 2008.

BECK, B.; BLANPAIN, C. Mechanisms regulating epidermal stem cells. The EMBO journal, v. 31, n. 9, p. 2067-75, maio. 2012.

BECKER, K. A. et al. Self-renewal of human embryonic stem cells is supported by a shortened G1 cell cycle phase. Journal of cellular physiology, v. 209, n. 3, p. 883-93, dez. 2006.

BEHR, B. et al. Stem cells. Plastic and reconstructive surgery, v. 126, n. 4, p. 1163-71, out. 2010.

BENTZINGER, C. F. et al. The emerging biology of muscle stem cells: Implications for cellbased therapies. BioEssays : news and reviews in molecular, cellular and developmental biology, v. 35, n. 3, p. 231-41, mar. 2013.

BLOMHOFF, R.; BLOMHOFF, H. K. Overview of retinoid metabolism and function. Journal of neurobiology, v. 66, n. 7, p. 606-30, jun. 2006.

BONGSO, A.; RICHARDS, M. History and perspective of stem cell research. Best practice \& research. Clinical obstetrics \& gynaecology, v. 18, n. 6, p. 827-42, dez. 2004. 
BOYER, L. A. et al. Core Transcriptional Regulatory Circuitry in Human Embryonic Stem Cells. v. 122, n. Icm, p. 947-956, 2005.

BREMMER, F. et al. N-cadherin expression in malignant germ cell tumours of the testis. BMC clinical pathology, v. 12, n. 1, p. 19, jan. 2012.

BRIGGS, B. R.; KING, T. J. TRANSPLANTATION OF LIVING NUCLEI FROM BLASTULA. v. 38, n. 1951, p. 455-463, 1952.

BRINSTER, R. L. The effect of cells transferred into the mouse blastocyst on subsequent development. The Journal of experimental medicine, v. 140, n. 4, p. 1049-56, 1 out. 1974.

BULLOCK, M. D. et al. MicroRNAs: critical regulators of epithelial to mesenchymal (EMT) and mesenchymal to epithelial transition (MET) in cancer progression. Biology of the cell / under the auspices of the European Cell Biology Organization, v. 104, n. 1, p. 3-12, jan. 2012.

CHAMBERS, I. et al. Functional expression cloning of Nanog, a pluripotency sustaining factor in embryonic stem cells. Cell, v. 113, n. 5, p. 643-55, 30 maio. 2003.

CHAMBERS, I. et al. Nanog safeguards pluripotency and mediates germline development. Nature, v. 450, n. 7173, p. 1230-4, dez. 2007.

CHANG, H.; GREGORY, R. I. MicroRNAs and reprogramming. Nature biotechnology, v. 29, n. 6, p. 499-500, jun. 2011.

COWIN, P.; WELCH, D. R. Breast cancer progression: controversies and consensus in the molecular mechanisms of metastasis and EMT. Journal of mammary gland biology and neoplasia, v. 12, n. 2-3, p. 99-102, set. 2007.

DAMOISEAUX, R. et al. Integrated chemical genomics reveals modifiers of survival in human embryonic stem cells. Stem cells (Dayton, Ohio), v. 27, n. 3, p. 533-42, mar. 2009.

DAVIS, R. L.; WEINTRAUB, H.; LASSAR, A B. Expression of a single transfected cDNA converts fibroblasts to myoblasts. Cell, v. 51, n. 6, p. 987-1000, 24 dez. 1987.

DEB-RINKER, P. et al. Sequential DNA methylation of the Nanog and Oct-4 upstream regions in human NT2 cells during neuronal differentiation. The Journal of biological chemistry, v. 280, n. 8, p. 6257-60, 25 fev. 2005.

DERYCKE, L. D. M.; BRACKE, M. E. N-cadherin in the spotlight of cell-cell adhesion, differentiation, embryogenesis, invasion and signalling. The International journal of developmental biology, v. 48, n. 5-6, p. 463-76, jan. 2004.

DOMINICI, M. et al. Minimal criteria for defining multipotent mesenchymal stromal cells. The International Society for Cellular Therapy position statement. Cytotherapy, v. 8, n. 4, p. 315-7, jan. 2006.

DRAPER, J. S. et al. Surface antigens of human embryonic stem cells: changes upon differentiation in culture. Journal of anatomy, v. 200, n. Pt 3, p. 249-58, mar. 2002. 
EGLI, D.; BIRKHOFF, G.; EGGAN, K. Mediators of reprogramming: transcription factors and transitions through mitosis. Nature reviews. Molecular cell biology, v. 9, n. 7, p. 50516, jul. 2008.

EIFERT, C. et al. Global Gene Expression Profiles Associated With Retinoic Acid-Induced Differentiation of Embryonal Carcinoma Cells. v. 824, n. April, p. 796-824, 2006.

EMA, M. et al. Krüppel-like factor 5 is essential for blastocyst development and the normal self-renewal of mouse ESCs. Cell stem cell, v. 3, n. 5, p. 555-67, 6 nov. 2008.

EVANS, M. J.; KAUFMAN, M. H. Establishment in culture of pluripotential cells from mouse embryos.Nature, jul. 1981.

FAHERTY, S.; KANE, M. T.; QUINLAN, L. R. Self-renewal and differentiation of mouse embryonic stem cells as measured by Oct 4 gene expression: effects of lif, serum-free medium, retinoic acid, and dbcAMP. In vitro cellular \& developmental biology. Animal, v. 41, n. 10 , p. 356-63, 2005.

FIELDS, A. L.; SOPRANO, D. R.; SOPRANO, K. J. Retinoids in biological control and cancer. Journal of cellular biochemistry, v. 102, n. 4, p. 886-98, 1 nov. 2007.

FINCH, B. W.; EPHRUSSI, B. Retention of multiple developmental potentialities by cells of a mouse testicular teratocarcinoma during prolonged culture in vitro and their extinction upon hybridisation with cells of permanent lines. Natl Acad. Sci., v. 57, p. 615-621, 1967.

FUJIKURA, J. et al. Differentiation of embryonic stem cells is induced by GATA factors. Genes \& development, v. 16, n. 7, p. 784-9, abr. 2002.

GASPAR-MAIA, A. et al. Open chromatin in pluripotency and reprogramming. Nature reviews. Molecular cell biology, v. 12, n. 1, p. 36-47, jan. 2011.

GIESBERTS, A N. et al. The expression and function of cadherin-mediated cell-to-cell adhesion in human embryonal carcinoma cells. Mechanisms of development, v. 83, n. 1-2, p. 115-25, maio. 1999.

GREBER, B.; LEHRACH, H.; ADJAYE, J. Silencing of core transcription factors in human EC cells highlights the importance of autocrine FGF signaling for self-renewal. v. 15, p. 1-15, 2007.

GRIGORIADIS, A E.; HEERSCHE, J. N.; AUBIN, J. E. Differentiation of muscle, fat, cartilage, and bone from progenitor cells present in a bone-derived clonal cell population: effect of dexamethasone. The Journal of cell biology, v. 106, n. 6, p. 2139-51, jun. 1988.

GRIMSON, A. et al. Article MicroRNA Targeting Specificity in Mammals : Determinants beyond Seed Pairing. p. 91-105, 2007.

GRONTHOS, S. Molecular and cellular characterisation of highly purified stromal stem cells derived from human bone marrow. Journal of Cell Science, v. 116, n. 9, p. 1827-1835, mar. 2003. 
GUMBINER, B. M. Regulation of cadherin-mediated adhesion in morphogenesis. Nature reviews. Molecular cell biology, v. 6, n. 8, p. 622-34, ago. 2005.

GUO, H. et al. Mammalian microRNAs predominantly act to decrease target mRNA levels. Nature, v. 466, n. 7308, p. 835-40, 12 ago. 2010.

GURDON, J. B. The developmental capacity of nuclei taken from intestinal epithelium cells of feeding tadpoles. Journal of embryology and experimental morphology, v. 10, n. December, p. 622-40, dez. 1962.

HANN, M. M.; OPREA, T. I. Pursuing the leadlikeness concept in pharmaceutical research. Current opinion in chemical biology, v. 8, n. 3, p. 255-63, jun. 2004.

HAY, E. D. An overview of epithelio-mesenchymal transformation.Acta anatomica, jan. 1995. Disponível em: <http://www.ncbi.nlm.nih.gov/pubmed/8714286>

HAYASHI, T.; CARTHEW, R. W. Surface mechanics mediate pattern formation in the developing retina. Nature, v. 431, n. 7009, p. 647-52, 7 out. 2004.

HORWITZ, E. M. et al. Clarification of the nomenclature for MSC: The International Society for Cellular Therapy position statement.Cytotherapy, jan. 2005.

ILANCHERAN, S.; MOODLEY, Y.; MANUELPILLAI, U. Human fetal membranes: a source of stem cells for tissue regeneration and repair? Placenta, v. 30, n. 1, p. 2-10, jan. 2009.

ILIC, D.; POLAK, J. M. Stem cells in regenerative medicine: introduction. British medical bulletin, v. 98, p. 117-26, jan. 2011.

JAENISCH, R.; YOUNG, R. Review Stem Cells , the Molecular Circuitry of Pluripotency and Nuclear Reprogramming. p. 567-582, 2008.

JAIN, A. K. et al. p53 regulates cell cycle and microRNAs to promote differentiation of human embryonic stem cells. PLoS biology, v. 10, n. 2, p. e1001268, jan. 2012.

JIRMANOVA, L. et al. Differential contributions of ERK and PI3-kinase to the regulation of cyclin D1 expression and to the control of the G1/S transition in mouse embryonic stem cells. Oncogene, v. 21, n. 36, p. 5515-28, 15 ago. 2002.

JONES-VILLENEUVE, E. M. et al. Retinoic acid induces embryonal carcinoma cells to differentiate into neurons and glial cells. The Journal of cell biology, v. 94, n. 2, p. 253-62, ago. 1982.

KAHAN, B. W.; EPHRUSSI, B. Developmental potentialities of clonal in vitro cultures of mouse testicular teratoma.Journal of the National Cancer Institute, maio. 1970. Disponível em: <http://www.ncbi.nlm.nih.gov/pubmed/5514468>

KERN, S. et al. Comparative analysis of mesenchymal stem cells from bone marrow, umbilical cord blood, or adipose tissue. Stem cells (Dayton, Ohio), v. 24, n. 5, p. 1294-301, maio. 2006. 
KIM, C. F. B. et al. Identification of bronchioalveolar stem cells in normal lung and lung cancer. Cell, v. 121, n. 6, p. 823-35, jun. 2005.

KOLIOS, G.; MOODLEY, Y. Introduction to stem cells and regenerative medicine. Respiration; international review of thoracic diseases, v. 85, n. 1, p. 3-10, jan. 2013.

KUO, C. et al. A novel role of miR-302/367 in reprogramming. Biochemical and biophysical research communications, v. 417, n. 1, p. 11-6, 6 jan. 2012.

KUO, C.; YING, S. Advances in microRNA-mediated reprogramming technology. Stem cells international, v. 2012, p. 823709, jan. 2012.

KURODA, K. et al. Canonical Wnt signaling induces BMP-4 to specify slow myofibrogenesis of fetal myoblasts. Skeletal muscle, v. 3, n. 1, p. 5, jan. 2013.

LEE, O. K. et al. Isolation of multipotent mesenchymal stem cells from umbilical cord blood. Blood, v. 103, n. 5, p. 1669-75, 1 mar. 2004.

LESSARD, J. A; CRABTREE, G. R. Chromatin regulatory mechanisms in pluripotency. Annual review of cell and developmental biology, v. 26, p. 503-32, jan. 2010.

LI, E. Chromatin modification and epigenetic reprogramming in mammalian development. Nature reviews. Genetics, v. 3, n. 9, p. 662-73, set. 2002.

LI, R. et al. A mesenchymal-to-epithelial transition initiates and is required for the nuclear reprogramming of mouse fibroblasts. Cell stem cell, v. 7, n. 1, p. 51-63, 2 jul. 2010.

LIAO, B. et al. MicroRNA cluster 302-367 enhances somatic cell reprogramming by accelerating a mesenchymal-to-epithelial transition. The Journal of biological chemistry, $v$. 286, n. 19, p. 17359-64, 13 maio. 2011.

LISTER, R. et al. Human DNA methylomes at base resolution show widespread epigenomic differences. Nature, v. 462, n. 7271, p. 315-22, 19 nov. 2009.

LOH, Y. et al. The Oct4 and Nanog transcription network regulates pluripotency in mouse embryonic stem cells. v. 38, n. 4, p. 431-440, 2006.

LOVE, J. M.; GUDAS, L. J. Vitamin A, differentiation and cancer. Current opinion in cell biology, v. 6, n. 6, p. 825-31, dez. 1994.

MAJO, F. et al. Oligopotent stem cells are distributed throughout the mammalian ocular surface. Nature, v. 456, n. 7219, p. 250-4, nov. 2008.

MARONE, M. et al. Cell cycle regulation in human hematopoietic stem cells: from isolation to activation.Leukemia \& lymphoma, mar. 2002.

MARTIN, G. R. Isolation of a pluripotent cell line from early mouse embryos cultured in medium conditioned by teratocarcinoma stem cells Developmental Biology: v. 78, n. 12, p. 7634-7638, 1981. 
MASUI, S. et al. Pluripotency governed by Sox 2 via regulation of Oct3/4 expression in mouse embryonic stem cells. Nature cell biology, v. 9, n. 6, p. 625-35, jun. 2007.

MATTICK, J. S. et al. RNA regulation of epigenetic processes. BioEssays : news and reviews in molecular, cellular and developmental biology, v. 31, n. 1, p. 51-9, jan. 2009.

MEISSNER, A. Epigenetic modifications in pluripotent and differentiated cells. v. 28, n. 10, p. 1079-1088, 2010.

MESHORER, E. et al. Hyperdynamic plasticity of chromatin proteins in pluripotent embryonic stem cells. Developmental cell, v. 10, n. 1, p. 105-16, jan. 2006.

MIGUEL, M. P. DE; FUENTES-JULIÁN, S.; ALCAINA, Y. Pluripotent stem cells: origin, maintenance and induction. Stem cell reviews, v. 6, n. 4, p. 633-49, dez. 2010.

MIMEAULT, M.; HAUKE, R.; BATRA, S. K. Stem cells: a revolution in therapeutics-recent advances in stem cell biology and their therapeutic applications in regenerative medicine and cancer therapies. Clinical pharmacology and therapeutics, v. 82, n. 3, p. 252-64, set. 2007.

MINTZ, B.; ILLMENSEE, K. Normal genetically mosaic mice produced from malignant teratocarcinoma cells. Proceedings of the National Academy of Sciences of the United States of America, v. 72, n. 9, p. 3585-9, set. 1975.

MOODLEY, Y. et al. Human amnion epithelial cell transplantation abrogates lung fibrosis and augments repair. American journal of respiratory and critical care medicine, v. 182, n. 5, p. 643-51, set. 2010 .

MOORE, K. A; LEMISCHKA, I. R. Stem cells and their niches. Science (New York, N.Y.), v. 311, n. 5769, p. 1880-5, 31 mar. 2006.

MOURELATOS, Z. Small RNAs: The seeds of silence. Nature, v. 455, n. 7209, p. 44-5, 4 set. 2008.

MURRAY, M. J.; SAINT, R. Photoactivatable GFP resolves Drosophila mesoderm migration behaviour. Development (Cambridge, England), v. 134, n. 22, p. 3975-83, nov. 2007.

NAKAGAWA, S.; TAKEICHI, M. Neural crest cell-cell adhesion controlled by sequential and subpopulation-specific expression of novel cadherins. Development (Cambridge, England), v. 121, n. 5, p. 1321-32, maio. 1995.

NIWA, H. et al. Self-renewal of pluripotent embryonic stem cells is mediated via activation of STAT3. p. 2048-2060, 1998.

NIWA, H. et al. Interaction between Oct3 / 4 and $\mathrm{Cdx} 2$ Determines Trophectoderm Differentiation. p. 917-929, 2005.

NIWA, H. Wnt: What's Needed To maintain pluripotency? Nature Publishing Group, v. 13, n. 9, p. 1024-1026, 2011. 
NIWA, H.; MIYAZAKI, J.; SMITH, A G. Quantitative expression of Oct-3/4 defines differentiation, dedifferentiation or self-renewal of ES cells. Nature genetics, v. 24, n. 4, p. 372-6, abr. 2000.

ODORICO, J. S.; KAUFMAN, D. S.; THOMSON, J. A. Multilineage differentiation from human embryonic stem cell lines. Stem cells (Dayton, Ohio), v. 19, n. 3, p. 193-204, jan. 2001 .

OVERTURF, K. et al. Serial transplantation reveals the stem-cell-like regenerative potential of adult mouse hepatocytes. The American journal of pathology, v. 151, n. 5, p. 1273-80, nov. 1997.

PACHERNÍK, J. et al. Neural differentiation of pluripotent mouse embryonal carcinoma cells by retinoic acid: inhibitory effect of serum. Physiological research / Academia Scientiarum Bohemoslovaca, v. 54, n. 1, p. 115-22, jan. 2005.

PAL, R.; RAVINDRAN, G. Assessment of pluripotency and multilineage differentiation potential of NTERA-2 cells as a model for studying human embryonic stem cells. Cell proliferation, v. 39, n. 6, p. 585-98, dez. 2006.

PARK, S.-Y. et al. miR-29 miRNAs activate p53 by targeting p85 alpha and CDC42. Nature structural \& molecular biology, v. 16, n. 1, p. 23-9, jan. 2009.

PASSIER, R.; MUMMERY, C. Origin and use of embryonic and adult stem cells in differentiation and tissue repair. Cardiovascular research, v. 58, n. 2, p. 324-35, 1 maio. 2003.

PELLEGRIN, S.; MELLOR, H. Actin stress fibres. Journal of cell science, v. 120, n. Pt 20, p. 3491-9, 15 out. 2007.

PÉREZ-POMARES, J. M.; MUÑOZ-CHÁPULI, R. Epithelial-mesenchymal transitions: a mesodermal cell strategy for evolutive innovation in Metazoans. The Anatomical record, v. 268, n. 3, p. 343-51, 1 nov. 2002.

PFAFF, N. et al. miRNA screening reveals a new miRNA family stimulating iPS cell generation via regulation of Meox2. EMBO reports, v. 12, n. 11, p. 1153-9, nov. 2011.

PFAFF, N. et al. miRNAs involved in the generation, maintenance, and differentiation of pluripotent cells. Journal of molecular medicine (Berlin, Germany), v. 90, n. 7, p. 747-52, jul. 2012.

PFAFFL, M. W. A new mathematical model for relative quantification in real-time RT-PCR. Nucleic acids research, v. 29, n. 9, p. e45, maio. 2001.

POLlARD, T. D.; COOPER, J. A. Actin, a central player in cell shape and movement. Science (New York, N.Y.), v. 326, n. 5957, p. 1208-12, 27 nov. 2009.

POPP, C. et al. Genome-wide erasure of DNA methylation in mouse primordial germ cells is affected by AID deficiency. Nature, v. 463, n. 7284, p. 1101-5, 25 fev. 2010. 
POTTER, E. The Cadherin-Catenin System: Implications for Growth and Differentiation of Endocrine Tissues. Endocrine Reviews, v. 20, n. 2, p. 207-239, 1 abr. 1999.

RAI, K. et al. DNA demethylation in zebrafish involves the coupling of a deaminase, a glycosylase, and gadd45. Cell, v. 135, n. 7, p. 1201-12, 26 dez. 2008.

RASMUSSEN, T. P. Embryonic stem cell differentiation: a chromatin perspective. Reproductive biology and endocrinology : RB\&E, v. 1, p. 100, 13 nov. 2003.

RATAJCZAK, M. Z. et al. Pluripotent and multipotent stem cells in adult tissues. Advances in medical sciences, v. 57, n. 1, p. 1-17, 1 jun. 2012.

REIK, W. Stability and flexibility of epigenetic gene regulation in mammalian development. Nature, v. 447, n. 7143, p. 425-32, 24 maio. 2007.

REIK, W. Epigenetic Reprogramming in Mammalian Development. v. 1089, n. 2001, 2012.

ROOIJ, D. G. DE; GROOTEGOED, J. A. Spermatogonial stem cells. Current opinion in cell biology, v. 10, n. 6, p. 694-701, dez. 1998.

ROSSANT, J. Stem cells from the Mammalian blastocyst. Stem cells (Dayton, Ohio), v. 19, n. 6, p. 477-82, jan. 2001.

SANDHU, J. K.; SIKORSKA, M.; WALKER, P. R. Characterization of Astrocytes Derived From Human NTera-2 / D1 Embryonal Carcinoma Cells. v. 614, p. 604-614, 2002.

SATO, N. et al. Molecular signature of human embryonic stem cells and its comparison with the mouse. Developmental biology, v. 260, n. 2, p. 404-13, ago. 2003.

SAYEGH, T. Y. EL; KAPUS, A; MCCULLOCH, C. A. Beyond the epithelium: cadherin function in fibrous connective tissues. FEBS letters, v. 581, n. 2, p. 167-74, 23 jan. 2007.

SCHNEUWLY, S.; KLEMENZ, R.; GEHRING, W. J. Redesigning the body plan of Drosophila by ectopic expression of the homoeotic gene Antennapedia. Nature, v. 325, n. 6107, p. 816-8, 1987.

SCHOFIELD, R. The relationship between the spleen colony-forming cell and the haemopoietic stem cell.Blood cells, jan. 1978.

SCHOORLEMMER, J. et al. Regulation of Oct-4 gene expression during differentiation of EC cells. Molecular biology reports, v. 21, n. 3, p. 129-40, jan. 1995.

SCHWARTZ, C. M. et al. NTera2: a model system to study dopaminergic differentiation of human embryonic stem cells. Stem cells and development, v. 14, n. 5, p. 517-34, out. 2005.

SEKIYA, I. et al. Expansion of human adult stem cells from bone marrow stroma: conditions that maximize the yields of early progenitors and evaluate their quality. Stem cells (Dayton, Ohio), v. 20, n. 6, p. 530-41, jan. 2002. 
SHAHHOSEINI, M. et al. Epigenetic analysis of human embryonic carcinoma cells during retinoic acid-induced neural differentiation. Biochemistry and cell biology $=$ Biochimie et biologie cellulaire, v. 88 , n. 3, p. 527-38, jun. 2010.

SHOOK, D.; KELLER, R. Mechanisms, mechanics and function of epithelial-mesenchymal transitions in early development. Mechanisms of development, v. 120, n. 11, p. 1351-83, nov. 2003.

SIMÕES, P. D.; RAMOS, T. Human pluripotent embryonal carcinoma NTERA2 cl.D1 cells maintain their typical morphology in an angiomyogenic medium. Journal of negative results in biomedicine, v. 6, p. 5, jan. 2007.

SMITH, A. A glossary for stem-cell biology. Nature, v. 441, n. 7097, p. 1060-1060, jun. 2006.

SMITH, A. G. et al. Inhibition of pluripotential embryonic stem cell differentiation by purified polypeptides. Nature, v. 336, n. 6200, p. 688-90, 15 dez. 1988.

SOLTER, D.; DOMINIS, M.; DAMJANOV, I. Embryo-derived teratocarcinoma: I. The role of strain and gender in the control of teratocarcinogenesis. International journal of cancer. Journal international du cancer, v. 24, n. 6, p. 770-2, 15 dez. 1979.

SOLTER, D.; SKREB, N.; DAMJANOV, I. Extrauterine growth of mouse egg-cylinders results in malignant teratoma. Nature, v. 227, n. 5257, p. 503-4, 1 ago. 1970.

STADLER, B. et al. Characterization of microRNAs involved in embryonic stem cell states. Stem cells and development, v. 19, n. 7, p. 935-50, jul. 2010.

STEAD, E. et al. Pluripotent cell division cycles are driven by ectopic Cdk2, cyclin A/E and E2F activities. Oncogene, v. 21, n. 54, p. 8320-33, 28 nov. 2002.

STEVENS, L. C.; VARNUM, D. S. The development of teratomas from parthenogenetically activated ovarian mouse eggs. Developmental biology, v. 37, n. 2, p. 369-80, abr. 1974.

STEWART, R. et al. Silencing of the expression of pluripotent driven-reporter genes stably transfected into human pluripotent cells. Regenerative medicine, v. 3, n. 4, p. 505-22, jul. 2008.

SU, W. et al. Bioluminescence reporter gene imaging characterize human embryonic stem cell-derived teratoma formation. Journal of cellular biochemistry, v. 112, n. 3, p. 840-8, mar. 2011.

SUÁREZ-ALVAREZ, B. et al. Epigenetic mechanisms regulate MHC and antigen processing molecules in human embryonic and induced pluripotent stem cells. PloS one, v. 5, n. 4, p. e10192, jan. 2010.

TADA, M. et al. Nuclear reprogramming of somatic cells by in vitro hybridization with ES cells. Current biology : CB, v. 11, n. 19, p. 1553-8, 2 out. 2001. 
TAKAHASHI, K.; YAMANAKA, S. Induction of Pluripotent Stem Cells from Mouse Embryonic and Adult Fibroblast Cultures by Defined Factors. Cell, v. 126, n. 4, p. 663-676, ago. 2006.

TAKEICHI, M. The cadherins: cell-cell adhesion molecules controlling animal morphogenesis. Development (Cambridge, England), v. 102, n. 4, p. 639-55, abr. 1988.

TAKEICHI, M. Morphogenetic roles of classic cadherins. Current opinion in cell biology, v. 7, n. 5, p. 619-27, out. 1995.

TAN, S.; BICKER, G. T urning teratocarcinoma cells into neurons : rapid differentiation of NT-2 cells in floating spheres Franc. v. 142, p. 161-167, 2003.

TAYLOR, D. L. Past, present, and future of high content screening and the field of cellomics. Methods in molecular biology (Clifton, N.J.), v. 356, p. 3-18, jan. 2007.

THOMSON, J. A. Embryonic Stem Cell Lines Derived from Human Blastocysts. Science, v. 282, n. 5391, p. 1145-1147, 6 nov. 1998.

TISCORNIA, G.; IZPISÚA BELMONTE, J. C.; IZPISU, J. C. MicroRNAs in embryonic stem cell function and fate. Genes \& development, v. 24, n. 24, p. 2732-41, 15 dez. 2010.

TOJKANDER, S.; GATEVA, G.; LAPPALAINEN, P. Actin stress fibers--assembly, dynamics and biological roles. Journal of cell science, v. 125, n. Pt 8, p. 1855-64, 15 abr. 2012.

TOLLERVEY, J. R.; LUNYAK, V. V. Epigenetics: judge, jury and executioner of stem cell fate. Epigenetics : official journal of the DNA Methylation Society, v. 7, n. 8, p. 823-40, ago. 2012.

TSAGIAS, N. et al. Placenta perfusion has hematopoietic and mesenchymal progenitor stem cell potential. Transfusion, v. 51, n. 5, p. 976-85, maio. 2011.

TZIMAS, G.; NAU, H. The role of metabolism and toxicokinetics in retinoid teratogenesis. Current pharmaceutical design, v. 7, n. 9, p. 803-31, 1 jun. 2001.

WILLIAMS, R. R. E. et al. Neural induction promotes large-scale chromatin reorganisation of the Mash1 locus. Journal of cell science, v. 119, n. Pt 1, p. 132-40, 1 jan. 2006.

WILMUT, I. et al. Viable offspring derived from fetal and adult mammalian cells. Nature, v. 385, n. 6619, p. 810-3, 27 fev. 1997.

WILMUT, I. et al. Viable offspring derived from fetal and adult mammalian cells. Cloning and stem cells, v. 9, n. 1, p. 3-7, jan. 2007.

XIA, X.; WONG, S. T. Concise review: a high-content screening approach to stem cell research and drug discovery. Stem cells (Dayton, Ohio), v. 30, n. 9, p. 1800-7, set. 2012.

XU, N. et al. MicroRNA-145 regulates OCT4, SOX2, and KLF4 and represses pluripotency in human embryonic stem cells. Cell, v. 137, n. 4, p. 647-58, 15 maio. 2009. 
YAMANAKA, S. A fresh look at iPS cells. Cell, v. 137, n. 1, p. 13-7, 3 abr. 2009.

YAMANAKA, S.; BLAU, H. M. Nuclear reprogramming to a pluripotent state by three approaches. Nature, v. 465, n. 7299, p. 704-12, 10 jun. 2010.

YAO, S. et al. Long-term self-renewal and directed differentiation of human embryonic stem cells in chemically defined conditions. Proceedings of the National Academy of Sciences of the United States of America, v. 103, n. 18, p. 6907-12, maio. 2006.

YAO, X. et al. A quantitative assay for measuring of bovine immunodeficiency virus using a luciferase-based indicator cell line. Virologica Sinica, v. 25, n. 2, p. 137-44, abr. 2010.

ZELLER, M.; STRAUSS, W. L. Retinoic acid induces cholinergic differentiation of NTera 2 human embryonal carcinoma cells. International journal of developmental neuroscience : the official journal of the International Society for Developmental Neuroscience, v. 13, $\mathrm{n}$. 5, p. 437-45, ago. 1995.

ZHANG, X. D. et al. Integrating experimental and analytic approaches to improve data quality in genome-wide RNAi screens. Journal of biomolecular screening, v. 13, n. 5, p. 378-89, jun. 2008.

ZHAO, Y.; SRIVASTAVA, D. A developmental view of microRNA function. Trends in biochemical sciences, v. 32, n. 4, p. 189-97, abr. 2007.

ZUK, P. A et al. Multilineage cells from human adipose tissue: implications for cell-based therapies. Tissue engineering, v. 7, n. 2, p. 211-28, abr. 2001.

ZUK, P. A. et al. Human adipose tissue is a source of multipotent stem cells. Molecular biology of the cell, v. 13, n. 12, p. 4279-95, dez. 2002. 